\author{
UNIVERSIDADE DE SÃO PAULO \\ ESCOLA DE ARTES, CIÊNCIAS E HUMANIDADES
}

KÁTIA CRYSTINA HIPÓLITO BEZERRA

\title{
ESTUDO DE REMOÇÃO DE COR DE EFLUENTES TÊXTEIS POR MEIO DO PROCESSO OXIDATIVO AVANÇADO: $\mathrm{UV} / \mathrm{H}_{2} \mathrm{O}_{2}$.
}




\section{KÁTIA CRYSTINA HIPÓLITO BEZERRA}

\section{ESTUDO DE REMOÇÃO DE COR DE EFLUENTES TÊXTEIS POR MEIO DO PROCESSO OXIDATIVO AVANÇADO: \\ $\mathrm{UV} / \mathrm{H}_{2} \mathrm{O}_{2}$.}

Dissertação apresentada à Escola de Artes, Ciências e Humanidades da Universidade de São Paulo para obtenção do título de Mestre em Ciências pelo Programa de Pósgraduação em Têxtil e Moda.

Versão corrigida contendo as alterações solicitadas pela comissão julgadora em 09 de setembro de 2015. A versão original encontra-se em acervo reservado na Biblioteca da EACH/USP e na Biblioteca Digital de Teses e Dissertações da USP (BDTD), de acordo com a Resolução CoPGr 6018, de 13 de outubro de 2011

Área de Concentração: Materiais e Processos Têxteis.

Orientadora: Profa. Associada Dra. Silgia Aparecida da Costa

São Paulo 
Autorizo a reprodução e divulgação total ou parcial deste trabalho, por qualquer meio convencional ou eletrônico, para fins de estudo e pesquisa, desde que citada a fonte.

CATALOGAÇÃO-NA-PUBLICAÇÃO

(Universidade de São Paulo. Escola de Artes, Ciências e Humanidades. Biblioteca)

Bezerra, Kátia Crystina Hipólito

Estudo de remoção de cor de efluentes têxteis por meio do processo oxidativo avançado : UV/ $\mathrm{H}_{2} \mathrm{O}_{2} /$ Kátia Crystina Hipólito Bezerra ; orientadora, Silgia Aparecida da Costa. - São Paulo, 2015 $123 \mathrm{f}$. : il.

Dissertação (Mestrado em Ciências) - Programa de PósGraduação em Têxtil e Moda, Escola de Artes, Ciências e Humanidades, Universidade de São Paulo Versão corrigida

1. Indústria têxtil - Aspectos ambientais. 2. Indústria têxtil Processos. 3. Corantes - Tratamento. 4. Efluentes. 5. Águas residuárias. I. Costa, Silgia Aparecida da, orient. II. Título.

CDD 22.ed. -677 
Nome: BEZERRA, Kátia Crystina Hipólito.

Título: Estudo de remoção de cor de efluentes têxteis por meio do processo oxidativo avançado: $\mathrm{UV} / \mathrm{H}_{2} \mathrm{O}_{2}$

Dissertação apresentada à Escola de Artes, Ciências e Humanidades da Universidade de São Paulo para obtenção do título de Mestre em Ciências pelo Programa de Pósgraduação em Têxtil e Moda.

Área de Concentração: Materiais e Processos Têxteis.

Aprovado em: 09 / 09 / 2015

\section{Banca Examinadora}

Prof. Dra. Silgia Aparecida Costa

Universidade de São Paulo. Escola de Artes Ciências e Humanidades

Prof. Dra. Geórgia Christina Labuto Araújo

Universidade Federal de São Paulo -UNIFESP

Prof. Dr. Mauricio Campos Araújo

Universidade de São Paulo. Escola de Artes Ciências e Humanidades 
A Deus por tornar este sonho possível. A minha mãe (in memorian) por ter sido uma grande inspiração em minha vida. Ao meu esposo que me apoiou durante toda esta jornada. Aos meus irmãos Rodrigo e Rogerio que sempre foram muito prestativos. Aos meus tios Wanderley Peres (in memorian), Valdira Hipólito Peres e Jorge Luiz Santos Hipólito que sempre acreditaram em mim. 
Agradeço a Deus, primeiramente pela sabedoria para a concretização deste trabalho.

À minha orientadora Prof. Dra. Silgia Aparecida da Costa, pela orientação, apoio, amizade, incentivo e, sobretudo paciência durante 0 processo de desenvolvimento deste trabalho.

A Prof. Dra. Sirlene Maria da Costa, pela dedicação e comprometimento para com este trabalho, onde esta contribuiu por meio de sugestões na metodologia e por todo o acompanhamento deste.

A Prof. Dra. Geórgia Christina Labuto Araújo pela colaboração na parte experimental desta dissertação.

A Universidade de São Paulo pela disponibilização das dependências e equipamentos da universidade.

Ao Ervin Sriubas Jr., pelo auxilio nas dependências do laboratório.

Ao Diretor da Escola SENAI "Francisco Matarazzo", Prof. Marcelo Costa, ao Coordenador Técnico, Prof. Paulo Sergio Salvi, pela disponibilização das dependências e equipamentos da escola.

A minha família, minha mãe Valdice (in memoriam), meu marido João Paulo, irmãos Rodrigo e Rogério e meus familiares que muito me apoiaram e compreenderam a minha ausência durante este período. 
RESUMO

BEZERRA, KCH. Estudo de remoção de cor de efluentes têxteis por meio do processo oxidativo avançado: $\mathrm{UV} / \mathrm{H}_{2} \mathrm{O}_{2}$. 2015. 123 f. Dissertação (Mestrado) - Escola de Artes, Ciências e Humanidades, Universidade de São Paulo, São Paulo, 2015.

A indústria têxtil utiliza grandes quantidades de água e como consequência gera efluente que apresenta um alto potencial de impacto ambiental. Este trabalho teve como objetivo o tratamento de efluentes têxteis produzidos com corantes reativos por processo de oxidação avançada $\mathrm{H}_{2} \mathrm{O}_{2} / \mathrm{UV}$, os efluentes foram produzidos em laboratório segundo as condições de processos industriais e foram utilizados nos estudos de reuso em um novo processo de tingimento. Foram produzidos efluentes através dos tingimentos com três corantes reativos um amarelo Drimaren $\mathrm{Cl}-2 \mathrm{R}$ um vermelho Drimaren Cl-5B e um azul Drimaren, na concentração de 1,1\% individualmente e em conjunto, compondo uma tricromia a 1,2\%. Foram adicionados 14,71 mmol. L $\mathrm{L}^{-1}$ peróxido de hidrogênio nas amostras residuais de efluentes e estas foram colocadas no reator de fotodegradação com radiação UV, foram utilizados como fonte de irradiação três lâmpadas de 6 Watts capazes de emissão de UV 1,7 Watts. As amostras foram coletadas e analisadas em intervalos de até 270 minutos de irradiação. Este processo foi executado em três faixas de $\mathrm{pH}$ diferentes, 4,0; 7,0 e 11,0 , sendo que no $\mathrm{pH} 4,0$ o processo foi mais eficiente com resultados de remoção de cor superiores a $91,12 \pm 3,09 \%$. Estas águas de reuso foram utilizadas para novos tingimentos nas mesmas condições e analisadas por meio de colorimetria resultando em valores de $\Delta \mathrm{E}$ menores que 0,62. Foram realizadas analises de carbono orgânico total (COT), as quais também corroboraram com os resultados anteriores, uma vez que demonstram que existe redução da carga orgânica de até $43,22 \%$. Foram realizadas medições de condutividade dos banhos e assim foi possível fazer a correção de cloreto de sódio nos banhos dos processos de tingimentos posteriores, permitindo assim a redução da adição de cloreto de sódio nos banhos.

Palavras-chave: Descoloração de corantes; corantes reativos; águas residuárias têxteis; $\mathrm{H}_{2} \mathrm{O}_{2} / U V$. 


\section{ABSTRACT}

BEZERRA, KCH. Study of color removal of textile effluents by means of advanced oxidation processes: $\mathrm{UV} / \mathrm{H}_{2} \mathrm{O}_{2}$. 2015. 123 f. Dissertação (Mestrado) - Escola de Artes, Ciências e Humanidades, Universidade de São Paulo, São Paulo, 2015.

The textile industry uses big quantities of water and normally as consequence the effluent has a high environmental impact. This study aimed treat textile effluents produced with reactive dyes by advanced $\mathrm{H}_{2} \mathrm{O}_{2}$ / UV oxidation process, the effluents were produced in the laboratory under conditions of industrial processes and have been used in studies of reuse in a new dying process. The effluents were produced by dying with three reactive yellow Drimaren dye $C L 2 R$, red Drimaren $C L 5 B$ and blue Drimaren HF-RL in concentration of $1.1 \%$ individually and in combination, comprising a trichromy of $1.2 \%$. In the waste effluent was added $14.71 \mathrm{mmol}^{-L^{-1}}$ hydrogen peroxide and these samples were placed on a photodegradation reactor where was used three lamps 6 Watts UV able to emit 1.7 Watts each of them. The samples were collected and analyzed at intervals of up to 270 minutes of irradiation. This process was performed in three different $\mathrm{pH}$ ranges, 4,0; 7,0 and 11,0, and at $\mathrm{pH} 4,0$ the process was more efficient with color removal rate higher than 91,12 \pm $3,09 \% . \%$.This reuse water has been used for new dying under the same conditions and analyzed through colorimetry resulting in lower $\Delta \mathrm{E}$ values than 0.62 . The total organic carbon analysis (TOC), which also corroborate the previous results, since it shows that there is a reduction of the organic load of up to $43.22 \%$. The bath conductivity measurements were carried out and it was possible to make the adjustment of sodium chloride in the further dying processes allowing the reduction of sodium chloride added in the baths.

Keywords: Dye decolourisation; reactive dyes; textile wastewater; $\mathrm{H}_{2} \mathrm{O}_{2} / \mathrm{UV}$. 


\section{Lista de Figuras}

Figura 1 - Principais fibras têxteis (BURTI et al. adaptada pelo autor, 2011)........................... 23

Figura 2 - Estrutura do corante antraquinona (SILVA et al., 2011)........................................... 31

Figura 3 - Mecanismo de redução dos corantes à tina (SILVA et al., 2011). .......................... 31

Figura 4 - Exemplos de Anéis heterocíclicos contendo enxofre (SALEM, 2010)................... 32

Figura 5 - Dissolução do naftolato de sódio (SILVA et al., 2011)............................................. 33

Figura 6 - Reação entre o naftolato sódico e o cloreto de sódio diazônio formando o corante

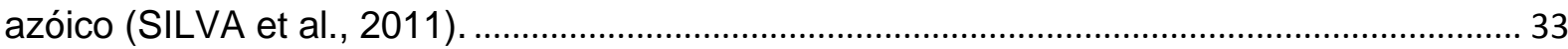

Figura 7 - Reação de adição nucleofílica (SALEM, 2010) .......................................................... 34

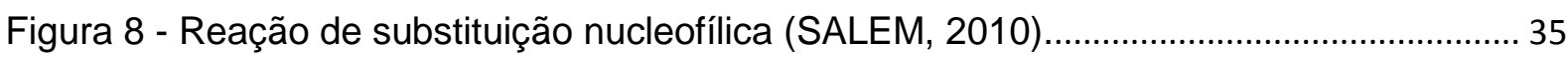

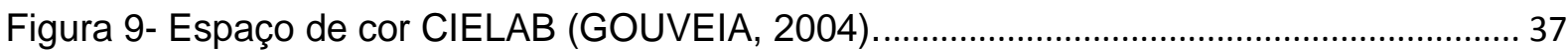

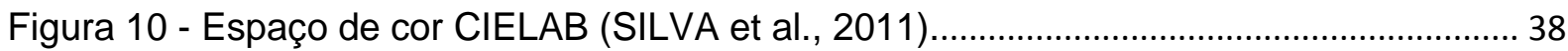

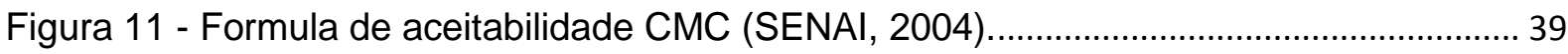

Figura 12 - Fluxograma do Processo de uma indústria têxtil (PERES e ABRAHÃO, 1998).. 42

Figura 13 - Interior do reator, placa de agitação magnética, lâmpadas de radiação UV,

mangueira e seringa para captação de amostras.................................................................... 58

Figura 14 - Gráfico da curva de montagem dos corantes, sendo que as letras A e B indicam os reagentes que foram adicionados conforme as Tabelas 11 e 12 (CLARIANT, 2005 adaptado pela autora).

Figura 15 - Gráfico de lavagem, sendo que as letras A e B indicam os reagentes que foram adicionados conforme a (CLARIANT, 2005 adaptado pela autora).

Figura 16 - Curva de calibração para concentrações acima de $10 \mathrm{~g} \cdot \mathrm{L}^{-1}$ de cloreto de sódio.

Figura 17 - Curva de calibração para concentrações inferiores a 1,2 g.L-1 de cloreto de

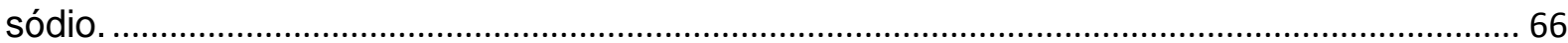

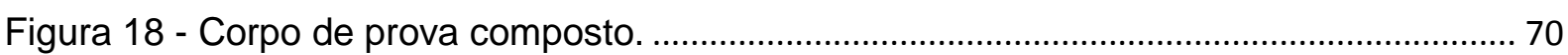

Figura 19 - Tingimentos executados com corante amarelo drimaren CL-2R. .......................... 74

Figura 20 - Tingimentos executados com corante vermelho drimaren CL-5B...................... 75

Figura 21 - Tingimentos executados com corante azul drimaren HF-RL.................................. 75

Figura 22- Tingimentos executados com a tricromia de corantes Drimaren. ............................ 76

Figura 23 - Absorbâncias nas faixas UV e visível em função do comprimento de onda em nm no tempo de 150 minutos de tratamento para o efluente com corante amarelo Drimaren CL-

$2 \mathrm{R}$

Figura 24 - Absorbâncias nas faixas UV e visível em função do comprimento de onda nm no tempo 240 minutos de tratamento para o efluente com corante vermelho Drimaren CL-5B. 81 Figura 25 - Absorbâncias nas faixas UV e visível em função do comprimento de onda em nm no tempo de 150 minutos de tratamento para o efluente com corante azul Drimaren HF-RL.

Figura 26 - Absorbâncias nas faixas UV e visível em função do comprimento de onda em nm no tempo de 270 minutos de tratamento para o efluente com a tricromia.

Figura 27 - Variação das absorbâncias do efluente bruto (efluente sintético produzido em laboratório com águas de lavagens) em $\mathrm{pH} 4,0$, faixa de $\mathrm{pH}$ que apresentou melhor remoção de cor na faixa do visível em função do comprimento de onda nm no tempo 150 minutos para o efluente produzidos com corante amarelo Drimaren CL-2R. 
Figura 28 - Variação das absorbâncias do efluente bruto (efluente sintético produzido em laboratório com águas de lavagens) em $\mathrm{pH} 4,0$, faixa de $\mathrm{pH}$ que apresentou melhor remoção de cor na faixa do visível em função do comprimento de onda nm no tempo 240 minutos para o efluente produzidos com corante vermelho Drimaren CL-5B.

Figura 29 - Variação das absorbâncias do efluente bruto (efluente sintético produzido em laboratório com águas de lavagens) em $\mathrm{pH} 4,0$, faixa de $\mathrm{pH}$ que apresentou melhor remoção de cor na faixa do visível em função do comprimento de onda nm no tempo 150 minutos para o efluente produzidos com corante azul Drimaren HF-RL

Figura 30 - Variação das absorbâncias do efluente bruto (efluente sintético produzido em laboratório com águas de lavagens) em $\mathrm{pH} 4,0$, faixa de $\mathrm{pH}$ que apresentou melhor remoção de cor na faixa do visível em função do comprimento de onda nm no tempo 270 minutos para o efluente produzidos com a tricromia.

Figura 31 - Resultado da decomposição fotoquímica do efluente produzido com a tricromia estudada por 270 min.

Figura 32 - Variação das absorbâncias dos efluentes tratados nas faixas UV e visível em função do comprimento de onda nm com a tricromia estudada.

Figura 33 - Variação das absorbâncias dos efluentes gerados pelos tingimentos com água potável e de reuso tratada por processo fotoquímico com $\mathrm{H}_{2} \mathrm{O}_{2} / U V$ nas faixas UV e visível em função do comprimento de onda nm com a tricromia estudada.

Figura 34- Corpos-de-prova compostos. 108

Figura 35 - Resultados dos ensaios de solidez da cor à luz dos tecidos tintos com a tricromia estudada.

Figura 36 - Escala azul de referência que foi colocada com os tecidos tintos com a tricromia estudada. 


\section{Lista de Tabelas}

Tabela 1 - Operações do sistema primário (SILVA et al. adaptado pela autora, 2011). 26

Tabela 2 - Classificação dos corantes por aplicação (SILVA et al adaptado pela autora, 2011)

Tabela 3 - Classificação dos corantes dispersos (SENAI, 2012)...

Tabela 4 - Principais tipos de corantes reativos, por ordem decrescente de reatividade (SILVA et al., 2011).

Tabela 5 - Poluentes associados ao tingimento têxtil por classe de corante (ABRAÃO e SILVA, 2002).

Tabela 6 - Estimativa do grau de fixação dos diferentes corantes nas fibras têxteis e perdas para o efluente, permitidos pela sociedade de corantes e colorações (BARRETO, 2006

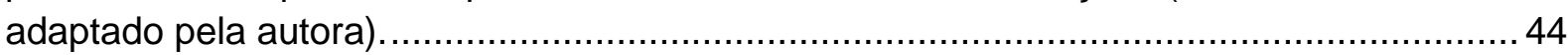

Tabela 7 - Processos de tratamento de efluentes (PERES e ABRAÃO, 1998).................... 45

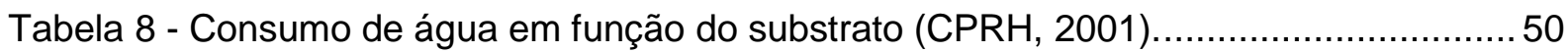

Tabela 9 - Estudo comparativo dos parâmetros de lançamento da Resolução CONAMA N`357/2005 e Decreto N 8468/76.

Tabela 10 - Receitas de tingimentos com corantes reativos bifuncional (CLARIANT, 2005).60

Tabela 11 - Cálculo da receita de tingimento para as monocromias. ....................................61

Tabela 12 - Cálculo da receita de tingimento para a tricromia..............................................62

Tabela 13 - Receita de lavagem para corantes reativos heterofucionais e os respectivos cálculos (CLARIANT, 2005).

Tabela 14 - Avaliação da escala cinza de alteração de cor (Fonte: NBR ISO 105-A 03, 2006).

Tabela 15 - Avaliação da escala cinza de transferência de cor (Fonte: NBR ISO 105-A 03, 2011).

Tabela 16 - Condições de ensaio (Fonte: ABNT NBR ISO 105-C06, 2010)........................ 71

Tabela 17 - Avaliação da escala azul de alteração de cor (Fonte: NBR ISO 105-B02, 2008).

Tabela 18 - Parâmetros iniciais e finais após tratamento fotoquímico em pH 4,0 do efluente produzido com corante amarelo Drimaren CL-2R, Vermelho Drimaren CL-5B e Azul

Drimaren HF-RL.

Tabela 19 - Parâmetros iniciais e finais após tratamento fotoquímico em pH 4,0 do efluente produzido com a tricromia de corantes reativos.

Tabela 20 - Porcentagem média de remoção da cor no efluente produzido com corante Amarelo Drimaren CL-2R nas faixas de $\mathrm{pH} 4,0,7,0$ e 11,0.....

Tabela 21 - Porcentagem média de remoção da cor no efluente produzido com corante

Vermelho Drimaren CL-5B nas faixas de $\mathrm{pH}$ 4,0, 7,0 e 11,0.

Tabela 22 - Porcentagem média de remoção da cor no efluente produzido com corante Azul

Drimaren HF- RL nas faixas de $\mathrm{pH}$ 4,0, 7,0 e 11,0.

Tabela 23 - Porcentagem média de remoção da cor no efluente produzido com a tricromia de corantes Drimaren nas faixas de $\mathrm{pH}$ 4,0, 7,0 e 11,0.....

Tabela 24 - Porcentagens de remoção de cor nos efluentes produzidos.

Tabela 25 - Porcentagem remanescente de cor entre os tratamentos de degradação

fotoquímica.

Tabela 26 - Comparativo da coloração residual entre os efluentes produzidos com água de reuso.

Tabela 27 - Variações de pH após o processo fotoquímico com $\mathrm{H}_{2} \mathrm{O}_{2} / \mathrm{UV}$. 
Tabela 28 - Correção do cloreto de sódio em função da curva de calibração da condutividade da água de reuso proveniente do tingimento com corante amarelo Drimaren

CL-2R

Tabela 29 - Correção do cloreto de sódio em função da curva de calibração da condutividade da água de reuso proveniente do tingimento com corante vermelho Drimaren CL-5B

Tabela 30 - Correção do cloreto de sódio em função da curva de calibração da condutividade da água de reuso proveniente do tingimento com corante azul Drimaren HF$\mathrm{RL}$.

Tabela 31 - Correção do cloreto de sódio em função da curva de calibração da condutividade da água de reuso proveniente do tingimento com tricromia de corantes Drimaren.

Tabela 32 - Estimativa de cálculo da economia financeira proveniente da correção do cloreto de sódio nos tingimentos com água de reuso com os corantes Drimaren utilizados individualmente.

Tabela 33 - Estimativa de cálculo da economia financeira proveniente da correção do cloreto de sódio nos tingimentos com água de reuso utilizando a tricromia de corantes Drimaren estudados.

Tabela 34- Resultados do decréscimo de COT durante o processo de tratamento com $\mathrm{H}_{2} \mathrm{O}_{2}$. 100

Tabela 35 - Resultados da leitura da cor dos tingimentos executados com as águas de reuso com o corante amarelo Drimaren CL-2R.

Tabela 36 - Resultados da leitura da cor dos tingimentos executados com as águas de reuso com o corante vermelho Drimaren CL-5B. 102 Tabela 37 - Resultados da leitura da cor dos tingimentos executados com as águas de reuso com o corante azul Drimaren HR-RL.

Tabela 38 - Resultados da leitura da cor dos tingimentos executados com as águas de reuso com a tricromia estudada.

Tabela 39 - Resultados do ensaio de solidez à lavagem aplicados nos tecidos tintos com a tricromia estudada.

Tabela 40 - Valores obtidos para ensaio de solidez da cor à luz dos tecidos tintos com a tricromia estudada 
1. Introdução e Justificativa 16

2. Revisão Bibliográfica 20

2.1 Indústrias Têxteis $\quad 20$

2.1.1 Histórico 20

2.1.2 Processos Produtivos $\quad 21$

2.1.3 Fibras Têxteis e Fiação 22

2.1.4 Tecelagem 24

2.1.5 Malharia 24

2.1.6 Beneficiamentos Têxteis 25

2.1.7 Colorimetria 36

2.1.8 Ensaios de Solidez a cor $\quad 39$

2.2 Processo Industrial e Tratamento de Efluentes 40

2.2.1 Processos Oxidativos Avançados 46

2.3 Poluição Provocada pela Indústria Têxtil e o Meio Ambiente 49

2.3.1 Evolução da Legislação Ambiental 52

3. Objetivos 56

4. Materiais e Métodos $\quad 57$

4.1 Materiais $\quad 57$

4.2 Metodologia $\quad 59$

4.2.1 Processos de Tingimentos $\quad 59$

4.2.2 Tratamento dos Efluentes Gerados por Meio de Fotocatálise 64 com $\mathrm{H}_{2} \mathrm{O}_{2} / \mathrm{UV}$

4.2.3 Tingimento com Efluente Tratado e Análise de Reprodução 65 da Cor

4.2.4 Ensaios de Solidez à Lavagem e a Luz 67

4.2.5 Análise de Carbono Orgânico Total 72

5. Resultados e Discussão 74

5.1 Perfil de Degradação do Corante 74

$\begin{array}{ll}\text { 5.1.1 Influencia do } \mathrm{pH} & 78\end{array}$

5.2 Tingimentos Utilizando os Efluentes Tratados pelo Processo 87 
$\mathrm{H}_{2} \mathrm{O}_{2} / \mathrm{UV}$

5.2.1 Influência da Condutividade 91

5.2.2 Carbono Total Orgânico 98

5.3 Avaliação da cor dos tingimentos executados com água de 100 reuso

$\begin{array}{ll}\text { 5.3.1 Testes de Solidezes à cor } & 105\end{array}$

6. Conclusões 111

$\begin{array}{ll}\text { 7. Perspectivas Futuras } & 113\end{array}$

$\begin{array}{ll}\text { Referências bibliográficas } & 114\end{array}$ 
AATCC: $\quad$ American Association of Textile Chemists and Colorists

ABIT: $\quad$ Associação Brasileira da Indústria Têxtil e de Confecção

ABNT: $\quad$ Associação Brasileira de Normas técnicas

AFNOR: Association Française de Normalisation

ASTM: $\quad$ American Society for Testing nas Materials

CA: $\quad$ Fibra de acetato de celulose

Cel: $\quad$ Fibra celulósica

CIE: Commission Internationale de l'Éclairage

CNI : $\quad$ Confederação Nacional das Industrias

COT: $\quad$ Carbono orgânico total

CT: $\quad$ Fibra de triacetato de celulose

DCT: Diclorotriazina

DIN: $\quad$ Deutsches Institut fur Normung e. V.

DFCP: Difluorcloropirimidina

FIESP: $\quad$ Federação das Indústrias do Estado de São Paulo

ISO: International Organization for Standardization

JIS: $\quad$ Japanese Industrial Standards

MCT: $\quad$ Monoclorotriazina

MFT: $\quad$ Monofluortriazina

PA: $\quad$ Fibra de poliamida

PAC: $\quad$ Fibra de acrílico 
PES: $\quad$ Fibra de poliéster

PIB: $\quad$ Produto Interno Bruto

POAs: $\quad$ Processo Oxidativo Avançado

S: $\quad$ Fibra de seda

SEMA: Secretaria Especial do Meio Ambiente

TCP: $\quad$ Tricloropirimidina

UV: $\quad$ Ultravioleta

VS: Vinilsulfônicos

WO: $\quad$ Fibra de lã 


\section{INTRODUÇÃO E JUSTIFICATIVA}

A indústria têxtil é considerada uma das mais antigas atividades industriais e pode ser considerada uma das principais percussoras da revolução industrial, sendo que desempenha um papel importante na economia mundial (ALVES, 2010).

Segundo a ABIT (Associação Brasileira da Indústria Têxtil e de Confecção), a indústria têxtil e de confecção brasileira é a sexta maior produtora do mundo, representando o equivalente a $3,5 \%$ do PIB (Produto Interno Bruto) total brasileiro (ABIT, 2012).

Em função de vivermos em uma sociedade consumista, onde os processos estão em crescente desenvolvimento, hoje a indústria têxtil foi obrigada desenvolver novas tecnologias com o intuito de atender as novas características dos mercados do vestuário, de cama, mesa e banho e de têxteis técnicos, estes requerem fibras, tecidos, cores, estampas e acabamentos diferenciados, o que remete a uma busca incessante por novas tecnologias e uma modernização do seu parque industrial (TWARDOKUS, 2004; FERREIRA et al., 2014).

A indústria têxtil passou por uma queda muito grande na década de 90 , segundo Fernandes e Cario (2008), "isto se deu em função da abertura econômica deste período", mas logo após na década seguinte retomou seu crescimento de forma moderada (Saito et al, 2010). No ano de 2011 o setor têxtil apresentou um faturamento de $U \$ 67$ bilhões, o que representa um crescimento de $11,2 \%$ em relação ao ano anterior, contudo no ano seguinte, segundo o Sindivestuário (Sindicato dos Vestuários) este foi reduzido para U\$ 57 bilhões, isto causado pela queda de produção e variação cambial do país (LOURENÇO, 2012).

Em contrapartida a este fator os problemas ambientais estão se tornando críticos e a legislação cada vez mais exigente, tudo isso em função de um passado formado de um crescimento populacional desmedido e o desenvolvimento desordenado da atividade industrial (HASSEMER, 2012). O desenvolvimento humano foi feito à custa da extração dos bens naturais através do uso desordenado dos seus recursos, este processo de exploração foi generalizado, não respeitando fronteiras, ou seja, abrangendo todo o planeta, não se preocupando e nem 
respeitando o meio ambiente. Estes fatores tornaram as condições de sobrevivência das gerações futuras comprometidas (FERREIRA et al., 2009).

Hoje a contaminação das águas naturais se tornou um problema muito grande e para tentar se adaptar a este novo cenário, as empresas estão criando programas de economia, tratamento e reutilização de água nos processos industriais, além de uma procura incessante para cumprir a legislação vigente e tudo isto sem aumentar os custos de processo. Segundo Ferreira et al. (2009) "As empresas almejam crescimento, estabilidade e lucratividade", porém têm sido obrigadas a cumprir a legislação no que diz respeito aos impactos ambientais gerados pelo seu processo produtivo, forçando-as a tratar seus respectivos efluentes antes de descarta-los (SANTANA, 2010).

Mediante a todo este cenário, temos a indústria têxtil que utiliza água na grande maioria dos processos, principalmente quando se trata da área de beneficiamentos têxteis (HASSEMER, 2012), onde geralmente as operações a utilizam como solvente universal e em quantidades muito altas, além de ter uma concentração elevada de matéria orgânica no efluente (SOUZA, 2006).

Segundo Conchon (1999) [...] há dez anos, quando a água tinha um custo baixo, era normal uma indústria têxtil ter uma relação de banho na ordem de 400 litros gerados de efluente por $\mathrm{Kg}$ de produto têxtil produzido. Mas com a escassez de água, e consequente elevação do seu custo, hoje é possível encontrar uma relação entre 50 e 60 (litros de efluente/Kg de produto). Mesmo os grandes geradores se encontram na marca de $100 \mathrm{~L} / \mathrm{Kg}$.

No Brasil o setor têxtil possui uma grande importância de mercado estando, segundo a Confederação Nacional da Industria (2012), responsável por gerar 1,7 milhões de empregos diretos e também possuir um faturamento anual de U\$60 bilhões. Este setor foi obrigado a se preocupar com a conservação dos recursos hídricos, pois "os resíduos produzidos, em geral, de composição diversificada, frequentemente contém poluentes tóxicos e resistentes aos sistemas de tratamentos convencionais" (SALGADO et al., 2009).

Os efluentes têxteis são normalmente coloridos isto porque, durante 0 tingimento, parte dos corantes utilizados não adere às fibras sendo arrastado com a 
água (LACERDA, 2004). A eficiência da fixação tende a variar conforme a classe do corante, a fibra e o processo de tingimento. No caso deste trabalho foram abordados minuciosamente as características dos corantes reativos, que segundo Gahr et al. (1994); LIZAMA et al. (2002), após um processo de tingimento, em media $30 \%$ dos corantes utilizados são descartados no efluente, pois não fixaram na fibra e estes por terem sofrido processo de hidrólise durante a coloração, não permite que sejam reutilizados. Além de cor, o efluente também possui temperatura elevada, forte variação de $\mathrm{pH}$, alta concentração de sais $\left(40\right.$ a $\left.100 \mathrm{~g} \cdot \mathrm{L}^{-1}\right)$ e tensoativos.

Segundo Guaratini e Zanoni (2000), em função da diversidade de artigos produzidos pela indústria têxtil, esta tem a obrigatoriedade de processar uma grande variedade de fibras e para que isto seja possível é necessário à utilização de mais de uma classe de corantes que com isto, tende a produzir efluentes bastante diversificados, os quais podem ter grandes variações de cor, $\mathrm{pH}$, DBO e DQO em pequenos intervalos de tempo (KUNZ e PERALTA-ZAMORA, 2002; SILVA, 2011).

A remoção da cor dos efluentes têxteis se tornou alvo de estudos e pesquisas nas ultimas duas décadas, em função não apenas da alta toxidade de alguns corantes, mas também pela detecção nos corpos receptores, uma vez que não só prejudicam a qualidade dos corpos de água como também impedem a penetração da luz prejudicando a atividade fotossintética e além de oferecer risco à vida aquática (CLAUSEN e TAKASHIMA, 2007).

Os processos oxidativos avançados - POAs atualmente tem sido alvo de atenção de pesquisadores como alternativa para o tratamento de águas residuárias, as quais os processos convencionais são incapazes de se obter resultados realmente satisfatórios (LIZAMA et al., 2002; HASSEMER, 2006; ALVES, 2010; DIAS et al., 2013).

Os POAs são muito eficientes na mineralização ou eliminação de grupos funcionais químicos com alto grau de toxidade presentes em alguns efluentes industriais tais como, por exemplo, o têxtil. Esta característica se mostra como um diferencial, pois alguns processos de tratamento de efluentes apenas mudam os contaminantes de estado físico, mas este ainda permanece no meio ambiente, como é o caso do processo de tratamento de efluentes físico-químicos (coagulação e floculação) (DIAS et al., 2013). 
O processo consiste na produção de radicais hidroxilas $\left(\mathrm{OH}^{\circ}\right)$ a partir do peróxido de hidrogênio $\left(\mathrm{H}_{2} \mathrm{O}_{2}\right)$, estes radicais são altamente oxidantes, inclusive com poder de oxidação superior ao do permanganato de potássio, dióxido de cloro e cloro (HASSEMER, 2006).

Segundo Azevedo et al. (2010) "Os POAs são divididos em sistemas homogêneos e heterogêneos, nos quais os radicais hidroxilas $\left(\mathrm{OH}^{\circ}\right)$ são gerados com ou sem irradiação ultravioleta". Os principais POAs são ozônio, Fenton (decomposição catalítica de peróxido de hidrogênio em meio ácido/ferroso), alguns semicondutores tais como óxido de zinco, alumínio ou dióxido de titânio, peróxido de hidrogênio e radiação ultravioleta (TEIXEIRA e JARDIM, 2004).

O principal objetivo deste trabalho foi o tratamento de efluente por processo de oxidação avançada $\mathrm{H}_{2} \mathrm{O}_{2} / \mathrm{UV}$. Os efluentes têxteis tintos com corantes reativos foram produzidos em laboratório segundo as condições de processos industriais e foram utilizados nos estudos de reuso em um novo processo de tingimento. 


\section{REVISÃO BIBLIOGRAFICA}

\subsection{Indústrias têxteis}

\subsubsection{Histórico}

O processo de industrialização no Brasil surgiu com a indústria têxtil, teve seu início antes da chegada dos portugueses, uma vez que os índios já praticavam atividades artesanais por meio de técnicas primitivas de entrelaçamento manual de fibras vegetais produzindo telas para diversos fins, inclusive para vestuário (SOUZA, 2006).

Pode-se afirmar que a mesma iniciou no período colonial, contudo, não tem continuidade, em função da política econômica que era determinada pela Metrópole, Portugal, que definia esta em função de suas necessidades. Um exemplo disto foi o alvará assinado por D. Maria I, em 1785 onde determinava o fechamento de todas as fábricas de tecidos, restringindo apenas as que fabricavam artigos grosseiros, estes eram destinados ao vestuário de escravos ou para empacotamento de embalagens. Esta determinação tinha como objetivo evitar que os empregados agrícolas ou extrativistas minerais se voltassem para a indústria (WEID, 1995).

Segundo Weid (1995), este alvará foi revogado com a chegada de D. João VI ao Brasil, porém a indústria não cresceu em função de um tratado feito entre Portugal e Inglaterra, onde as taxas alfandegárias foram reduzidas para $15 \%$, fator que tornou impossível a concorrência dos tecidos nacionais com os tecidos ingleses. Em 1844, surgiu um novo sistema tarifário, onde a tarifa de $15 \%$ passou a $30 \%$ e com isso veio o crescimento da industrialização brasileira, e a indústria têxtil foi uma das precursoras (HASSEMER, 2006).

Ainda que este crescimento não fosse imediato, em 1864 o país já possuía 20 fábricas, com aproximadamente 15.000 fusos e 385 teares. Em 1881, este número cresceu para 44 fábricas e 60.000 fusos, gerando aproximadamente 5.000 empregos. Este crescimento permaneceu nas décadas seguintes, onde às vésperas da I Guerra Mundial, tínhamos 200 fábricas, que empregavam 78.000 pessoas funcionando no Brasil (SERAFINI, 2013). 
Atualmente a indústria têxtil desempenha um papel significativo na economia de diversos países, representa um dos setores mais antigos dentro do ramo industrial. A respeito da indústria têxtil brasileira, ocupa um espaço significativo dentro da economia uma vez que, segundo dados da ABIT é responsável por 1,7 milhão de empregos diretos e 8 milhões se for considerado os indiretos também, ou seja, o segundo maior gerador de empregos no pais, com trinta mil empresas formais em todo o território nacional (ABIT, 2012).

Levando em consideração os dados mencionados, pode-se concluir que em termos de empregos e processo produtivo, a indústria têxtil representa uma das maiores do mundo, mas é importante ser considerado que estes dados não representam apenas as empresas de grande porte, mas também as empresas pequenas com processos artesanais. É de suma importância ressaltar que estas foram as que mais sofreram no início da década de 90, segundo Paulo Skaf, presidente da FIESP (Federação das Indústrias do Estado de São Paulo), "com a abertura da economia que foi iniciada pelo governo Collor, a indústria têxtil e de confecção passou por sérios problemas em função da concorrência externa, muitas empresas apenas desapareceram e as demais foram obrigadas a se adaptar ao novo formato do mercado que exigiu uma profunda reestruturação levando à uma total modernização do seu parque fabril” (ABIT, 2002).

O setor se tornou eficiente e desenvolvido, e uma das explicações plausíveis seria que atualmente o Brasil é capaz de produzir sua própria tecnologia, desenvolvendo novos artigos, fibras, estampas, acabamentos e novos processos, além do investimento significativo no campo da pesquisa, tanto que o Brasil hoje é referência mundial em design de moda praia, jeanswear e homewear e estando em constante crescimento nos segmentos de fitness e lingerie (ABIT, 2002).

\subsubsection{Processos Produtivos}

As indústrias têxteis são responsáveis por produzir uma série diversificada de artigos têxteis que são desenvolvidos conforme as exigências do mercado para cada segmento, dentre eles podem ser citados, por exemplo: tecidos para vestuário em geral, automotivos, cama, mesa, banho e tecidos técnicos, etc. 
A cadeia têxtil é composta de setores, ou seja, um ramo específico onde se agrupam atividades relacionadas à mesma. Estes setores são:

- $\quad$ Fibras Têxteis e Fiação;

- Tecelagem;

- Malharia;

- Beneficiamentos Têxteis;

- Confecção.

O setor da cadeia têxtil enfatizado neste trabalho foi o de Beneficiamento Têxtil, é a área onde $90 \%$ dos processos são químicos, e se utiliza uma elevada quantidade de água (BELTRAME, 2000).

\subsubsection{Fibras Têxteis e Fiação}

A indústria têxtil produz artigos com diversas fibras, cada uma destas são adequadas para determinados produtos, isto justifica a grande variedade existente de fluxos de processos de produção. A Figura 1 mostra a classificação das principais fibras têxteis que podem ser encontradas no mercado segundo Burti et al. (2011).

A principal diferenciação entre fibras é que existem fibras naturais, as quais são compostas por macromoléculas obtidas e/ou fornecidas pela natureza, quer seja de origem animal (seda e lã), mineral (amianto ou asbesto) ou vegetal (algodão, linho, juta, rami), ao passo que as fibras químicas são formadas por macromoléculas obtidas por meio de sínteses químicas (Burti et al. 2011).

Neste trabalho foram utilizadas fibras celulósicas naturais, mas precisamente a fibra de algodão. Na fiação, o algodão é processado nos abridores, batedores, cardas, passadores, penteadeiras, maçaroqueiras, filatórios, retorcedeiras e conicaleiras (ABRAHÃO E SILVA, 2002). 


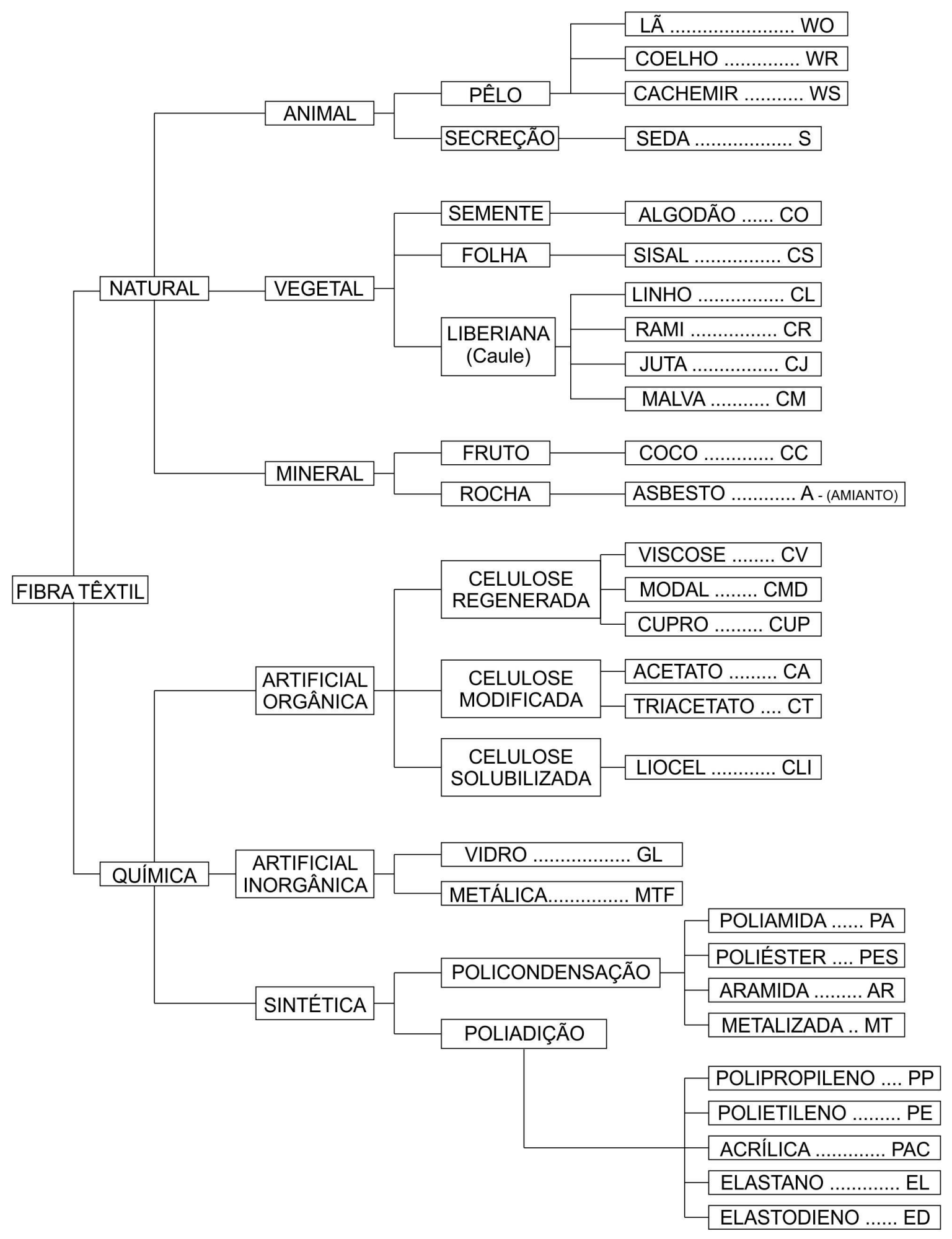

Figura 1 - Principais fibras têxteis (BURTI et al. adaptada pelo autor, 2011). 


\subsubsection{Tecelagem}

A tecelagem pode ser descrita pelo cruzamento de dois conjuntos de fios paralelos que se cruzam formando um ângulo reto. No sentido vertical se encontra os fios de urdume no sentido horizontal a trama. No processo de tecimento os fios de urdume tendem a sofrer muito atrito e tensão no tear, portanto, para aumentar a resistência deste conjunto de fios aplica-se o processo de engomagem (BELTRAME, 2000).

A engomagem consiste na aplicação e revestimento dos fios de urdume com substâncias adesivas e formadoras de um filme. Estas gomas tem a responsabilidade de tornar a superfície do fio mais lisa diminuindo tensão e atrito (ALCANTARA e DALTIN, 1996).

Os principais tipos de gomas utilizadas são à base de amido de milho, fécula de batata, mandioca; álcool polivinílico, carboximetilcelulose e poliacrilato (BELTRAME, 2000; SILVA et al., 2011).

\subsubsection{Malharia}

A malharia também caracteriza um setor de tecimento, porém não se utiliza o processo de trama e urdume, a mesma utiliza o entrelaçamento de um fio consigo mesmo, que caracteriza o processo de malharia de trama ou de vários fios longitudinais, chamado de malharia de urdume. Nas duas situações ocorre a formação da malha, "com cada laçada passando por dentro da laçada anterior, sem que haja um ponto fixo de ligação entre elas" (SILVA et al., 2011).

\subsubsection{Beneficiamentos Têxteis}

O beneficiamento têxtil é a área responsável por um conjunto de atividades que uma vez aplicadas ao substrato têxtil, dão ao mesmo as características técnicas e estéticas, exigidos pelo consumidor (SALEM, 2010).

Dentro deste segmento se encontram as tinturarias, estamparias e lavanderias. As tinturarias trabalham com fios, manchões, tecidos planos e de 
malha; as estamparias trabalham tanto com tecidos planos como malhas e peças confeccionadas; já as lavanderias trabalham apenas com peças confeccionadas.

Como para o beneficiamento têxtil, as alterações sempre são relacionadas ao processo e maquinário e não com a forma do material a ser processado, logo este é chamado de substrato têxtil (SILVA et al., 2011).

\section{Tinturaria}

Os processos produtivos de uma tinturaria são divididos em três grandes sistemas: primário, secundário e terciário.

O sistema Primário compreende todas as operações executadas com a finalidade de preparar o substrato têxtil para receber a coloração, conforme a Tabela 1.

O sistema Secundário compreende todas as operações executadas com a finalidade de colorir o substrato têxtil, ou seja, a operação de tingimento propriamente dita ou de estamparia (SILVA et al., 2011).

A história mostra que os corantes eram derivados de substâncias extraídas de animais, folhas, ramos, raízes, frutos e flores de várias plantas até a metade do século XIX. A indústria de corantes nasceu na Europa no século XVI, o primeiro corante sintético foi descoberto em 1856 na Inglaterra. Posteriormente a Alemanha conseguiu o monopólio sobre os corantes sintéticos. Os Estados Unidos é um grande exportador de corantes com aproximadamente 2000 tipos de corantes diferentes no mercado (GUARATINI e ZANONI, 2000).

A indústria têxtil utiliza aproximadamente 10000 diferentes tipos de corantes e pigmentos, com produção anual de cerca de $7 \times 10^{5}$ toneladas, dos quais aproximadamente $50 \%$ possuem em suas moléculas o grupamento azo $(-\mathrm{N}=\mathrm{N}-)$, sendo este potencialmente perigoso, uma vez que são conhecidos por seus efeitos tóxicos, carcinogênicos e mutagênicos (TANG e AN, 1995; LAU et al., 2014). 
Tabela 1 - Operações do sistema primário (SILVA et al. adaptado pela autora, 2011).

\begin{tabular}{|c|c|}
\hline Operação & Finalidade \\
\hline Chamuscagem & $\begin{array}{l}\text { Visa à eliminação das fibrilas do } \\
\text { substrato têxtil através da queima, pois } \\
\text { estas permanecem eriçadas na } \\
\text { superfície do fio ou do substrato } \\
\text { concedendo um aspecto áspero e } \\
\text { desuniforme. }\end{array}$ \\
\hline Navalhagem & $\begin{array}{l}\text { Elimina as fibrilas do substrato têxtil por } \\
\text { meio do corte, específico para fibras de } \\
\text { lã, poliéster, poliamida e suas misturas. }\end{array}$ \\
\hline Mercerização & $\begin{array}{l}\text { Visa aumentar o brilho, a resistência, a } \\
\text { afinidade do corante para com a fibra, a } \\
\text { hidrofilidade e diminuir o encolhimento } \\
\text { do substrato têxtil. }\end{array}$ \\
\hline Desengomagem & $\begin{array}{l}\text { Retira do tecido a goma aplicada na } \\
\text { tecelagem. }\end{array}$ \\
\hline Limpeza & $\begin{array}{l}\text { Eliminam do substrato têxtil as } \\
\text { substâncias químicas que impedem a } \\
\text { penetração da água e outras sujidades; }\end{array}$ \\
\hline Alvejamento & $\begin{array}{l}\text { Torna o substrato têxtil alvo retirando a } \\
\text { pigmentação natural. }\end{array}$ \\
\hline
\end{tabular}

Segundo Salem (2010), os corantes possuem quatro grupos funcionais, sendo eles: cromóforos que são responsáveis pela cor; auxocromos que caracteriza a intensidade e sua afinidade tintorial; solubilizantes que trata da solubilidade dos mesmos e os que proporcionam as ligações com a fibra. 


\section{Classificação dos corantes em função da fibra}

Conforme já fora descrito neste trabalho, um dos fatores preponderantes para a escolha do corante a ser utilizado é a fibra que se deseja tingir. A

Tabela 2 demonstra as classes de corantes e as respectivas fibras a serem tintas.

Tabela 2 - Classificação dos corantes por aplicação (SILVA et al adaptado pela autora, 2011).

\begin{tabular}{|c|c|c|c|c|c|c|c|c|}
\hline Corantes/Fibras & Cel & WO & $\mathbf{S}$ & $\mathbf{C A}$ & CT & PA & PES & PAC \\
\hline Direto & $x$ & & $x$ & & & & & \\
\hline Reativo & $x$ & & $x$ & & & & & \\
\hline Sulfurosos & $x$ & & & & & & & \\
\hline Azoico & $x$ & & & & & & & \\
\hline À tina & $x$ & & & & & & & \\
\hline Catiônicos & & & & & & & & $x$ \\
\hline Ácidos & & $x$ & $x$ & & & $x$ & & \\
\hline $\begin{array}{l}\text { Complexos } \\
\text { metálicos }\end{array}$ & & $x$ & $x$ & & & $x$ & & \\
\hline Dispersos & & & & $x$ & $x$ & & $x$ & \\
\hline Branco ótico & $x$ & $X$ & $x$ & $x$ & $x$ & $x$ & $\mathrm{X}$ & $x$ \\
\hline $\begin{array}{r}\text { Sendo Cel: } \\
\text { de celulose; PA: po }\end{array}$ & $\begin{array}{l}\text { fibra c } \\
\text { liamida }\end{array}$ & $\begin{array}{l}\text { sica; } \\
\text { S: pc }\end{array}$ & & $\begin{array}{l}\text { seda; } \\
\text { C: ac }\end{array}$ & $\begin{array}{l}\text { A: ac } \\
\text { O. }\end{array}$ & $\mathrm{de}$ & lose CT & triacetato \\
\hline $\begin{array}{l}\text { O process } \\
\text { diferentes, os qu } \\
\text { características d } \\
\text { tingimento e da su }\end{array}$ & $\begin{array}{l}0 \text { de } \\
\text { ais sã } \\
\text { proc }\end{array}$ & $\begin{array}{l}\text { imen } \\
\text { lassif } \\
\text { fina }\end{array}$ & 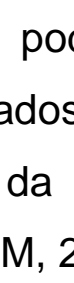 & $\begin{array}{l}\text { er } f \in \\
\text { fun }\end{array}$ & co & $\begin{array}{l}\text { ez c } \\
\text { ras }\end{array}$ & $\begin{array}{l}\text { ses de } \\
\text { erem } t\end{array}$ & $\begin{array}{l}\text { corantes } \\
\text { tas, das } \\
\text { ssos de }\end{array}$ \\
\hline
\end{tabular}




\section{Corante Branco}

Usados para os tingimentos de substratos brancos ou como preparação de tecidos que deverão ser estampados posteriormente. O branco é um tingimento efetuado com a aplicação de corantes, em sua maioria derivados de stilbeno, que possuem a propriedade de refletir ondas eletromagnéticas na faixa do ultravioleta (de comprimentos de onda inferior á 400nm) (SALEM, 2010).

Existem seis tipos de branqueadores óticos, uma vez que cada fibra terá afinidade com um dado tipo, os mais importantes são os que possuem um ou dois grupamentos stilbenos, os quais correspondem a $80 \%$ dos brancos óticos existentes (SILVA et al., 2011).

\section{Corantes ácidos e complexo metálico}

Utilizados para tingimento das fibras de poliamida, lã e seda. São corantes solúveis em água isto graças aos grupos sulfônicos inseridos em sua molécula que podem ser de um a três (GUARATINI e ZANONI, 2000). São ácidos orgânicos cíclicos ligados a grupo cromóforos, porém, por razões de fabricação e armazenamento são produzidos na forma de sais sódicos e são aplicados em banhos ácidos (SALEM, 2010).

Guaratini e Zanoni (2000) afirmam que os corantes ácidos se ligam a fibra por troca iônica utilizando um par eletrônico livre dos grupos amino e carboxilato das fibras protéicas.

Os corantes complexos metálicos são tintos por meio de um processo semelhante ao tingimento com corantes ácidos, contudo a sua utilização é requerida se $\mathrm{o}$ objetivo for ter índices de solidezes às lavagens melhores. Estes corantes possuem um átomo de um metal em sua estrutura, normalmente este é o cromo (SENAI, 2012). 


\section{Corantes Dispersos}

São corantes pouco solúveis em água. São utilizados para o tingimento de fibras de poliéster, acetato e poliamida, contudo são mais aplicáveis para o tingimento de fibras de poliéster (SALEM, 2010; SENAI, 2012).

Sua classificação se dá em função do tamanho da molécula do corante como demonstra a Tabela 3:

Tabela 3 - Classificação dos corantes dispersos (SENAI, 2012).

\begin{tabular}{|c|c|c|c|}
\hline Classificação & Igualização & $\begin{array}{c}\text { Solidez a } \\
\text { Sublimação }\end{array}$ & $\begin{array}{c}\text { Temperatura } \\
\text { de Tingimento } \\
\left({ }^{\circ} \mathrm{C}\right)\end{array}$ \\
\hline $\begin{array}{c}\text { Baixa energia ou } \\
\text { moléculas pequenas }\end{array}$ & Excelente & Pobres & 120 até 125. \\
\hline $\begin{array}{l}\text { Média energia } \\
\text { molécula média }\end{array}$ & Boa & Boa & 120 até 130. \\
\hline $\begin{array}{l}\text { Alta energia ou } \\
\text { molécula grande }\end{array}$ & Baixa & Excelente & 125 até 135. \\
\hline
\end{tabular}

Os valores apresentados na Tabela 3 mostram que quanto maior a molécula de corante, mais energia será necessário para o tingimento, uma vez que será preciso arraste da mesma, para que seja feita a adsorção e difusão pela fibra. Em baixas temperaturas, as cadeias poliméricas da fibra de poliéster estão praticamente paradas, a medida que é fornecido calor para o meio, aumenta a vibração e automaticamente aumenta a mobilidade nas regiões amorfas da fibra, abrindo alguns espaços para que haja a difusão do corante (SILVA et al., 2011).

\section{Corantes Básicos ou catiônicos}

Desenvolvidos para o tingimento de fibras acrílicas, possui este nome devido às cargas positivas. $\mathrm{O}$ corante se liga a fibra por meio de ligações iônicas (IMMICH, 2006; LUCAS et al., 2008). 
O processo de tingimento ocorre a $105^{\circ} \mathrm{C}$, e para impedir uma montagem desigual dos corantes, deve-se trabalhar com o pH do banho tamponado com um ácido e um cloreto de sódio que são utilizados como uma solução tampão (SILVA et al., 2011).

\section{Corantes diretos}

Esta classe de corante é utilizada para fibras celulósicas, são corantes solúveis em água e substantivos. Ligam-se a fibra têxtil através de pontes de hidrogênio e forças de Van der Waals, em função de serem ligações fracas, os tecidos tintos com este corante possuem baixo índice de solidez a processos úmidos, mas em contrapartida excelentes índices de solidez a luz, por isso se torna adequado para utilização em artigos de tapeçaria (SILVA et al., 2011).

Em função de seu caráter aniônico, este tingimento requer apenas um eletrólito que pode ser o cloreto ou sulfato de sódio para modificar parcialmente o caráter iônico da celulose, que em meio aquoso esta também irá ter o caráter igual ao do corante (SALEM, 2010).

\section{Corantes a Tina}

Esta classe de corante também é utilizada para fibras celulósicas, é originário do composto antraquinona (Figura 2), esta classe de corante se torna peculiar por ser insolúvel na forma comercial, se comportando como um pigmento (SILVA et al., 2011). Para que ocorra o processo de tingimento é necessário reduzi-lo com hidrossulfito de sódio em ambiente alcalino para que este se torne solúvel em água, uma vez que esta é o veículo condutor do corante até a fibra (GUARATINI e ZANONI, 2000 e SILVA et al., 2011). 


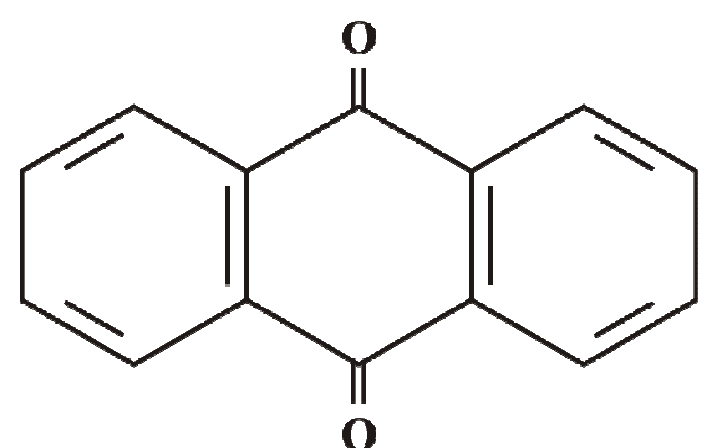

Figura 2 - Estrutura do corante antraquinona (SILVA et al., 2011).

Durante processo de redução é fornecido um átomo de sódio a sua molécula, o corante possui um grupo químico chamado cetônico $(\mathrm{C}=\mathrm{O})$, que se une ao íon de sódio formando um leuco derivado sódico ( $\mathrm{C}-\mathrm{ONa}$ ). Após o corante estar aplicado na fibra, conforme demonstrado na Figura 3. Este é novamente oxidado, com peróxido de hidrogênio, tornando-se insolúvel em água novamente. Em função desta modificação, os índices de solidez aos tratamentos úmidos e agentes de intemperismo são excelentes (SILVA et al., 2011).<smiles>CC1=C(C)C(=O)C(C)=C(C)C1=O</smiles>

Forma oxidada insolúvel em água

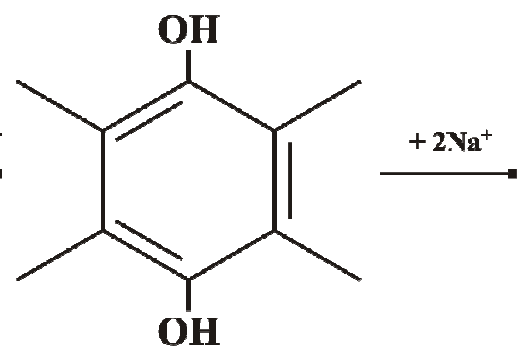

Leuco derivado solúvel em soluções alcalinas<smiles>Cc1c(C)c([NH3+])c(C)c(C)c1[NH3+]</smiles>

Leuco derivado de sódio solúvel em água

Figura 3 - Mecanismo de redução dos corantes à tina (SILVA et al., 2011).

\section{Corantes sulfurosos}

A designação de corante sulfuroso é aplicada a corantes orgânicos com um átomo de enxofre em sua molécula, pode estar na forma de ligações dissulfídricas entre grupos cromóforos ou pode estar ainda na parte integrante do cromóforo (ESTEVES, 2000). 
Segundo Silva et al. (2011) estes corantes são obtidos através de reações a altas temperaturas entre enxofre e sulfetos alcalinos e alguns compostos orgânicos que normalmente possuem grupos nitro e aminos, gerando átomos de enxofre em anéis heterocíclicos (Figura 4).<smiles>Cc1c2nc3c(C)c(C)c(C)c(C)c3sc-2c(C)c(=O)c1C</smiles>

Tiazona<smiles>c1cscn1</smiles>

Tiazol<smiles>Cc1c(C)c(C)c2c(c1C)Sc1c(C)c(C)c(C)c(C)c1S2</smiles>

Tianthrene

Figura 4 - Exemplos de Anéis heterocíclicos contendo enxofre (SALEM, 2010).

Estes corantes são insolúveis em água, mas podem tornar-se solúveis em soluções alcalinas e na presença de um redutor, no passado eram utilizados o sulfeto de sódio, mas o odor desprendido durante o processo de tingimento era muito desagradável e por isso atualmente se utiliza glicose ou gluconato de sódio (SILVA et al., 2011).

O princípio do processo de tingimento desta classe de corante é idêntico ao corante à tina, citado no item anterior, o corante é reduzido, tornando-se solúvel em água, após o processo de tingimento, este é oxidado, tornando-se novamente insolúvel, proporcionando assim, nos artigos têxteis excelentes índices de solidez á processos úmidos.

\section{Corantes azóicos}

Thomas e Robert Holliday, no ano de 1880 , concebeu a ideia de sintetizar corantes insolúveis dentro da própria fibra, dá-se ai, o desenvolvimento dos primeiros corantes azóicos (SALEM, 2010).

O processo de formação do corante é realizado em duas etapas, a primeira é tornar os naftóis, que são compostos fenólicos insolúveis em água, solúveis por meio de uma solução alcalina, produzindo assim o naftolato de sódio (Figura 5). Este é aplicado no substrato têxtil e a seguir, utiliza-se um composto chamado de 
base para naftol, esta é tratada com ácido nitroso e posteriormente aplicada também na fibra. Neste momento é feita a formação do corante, (Figura 6), que evidência esta transformação envolvendo a base diazotada que se tornou o cloreto de sódio diazônio e o naftolato sódico (SILVA et al., 2011).

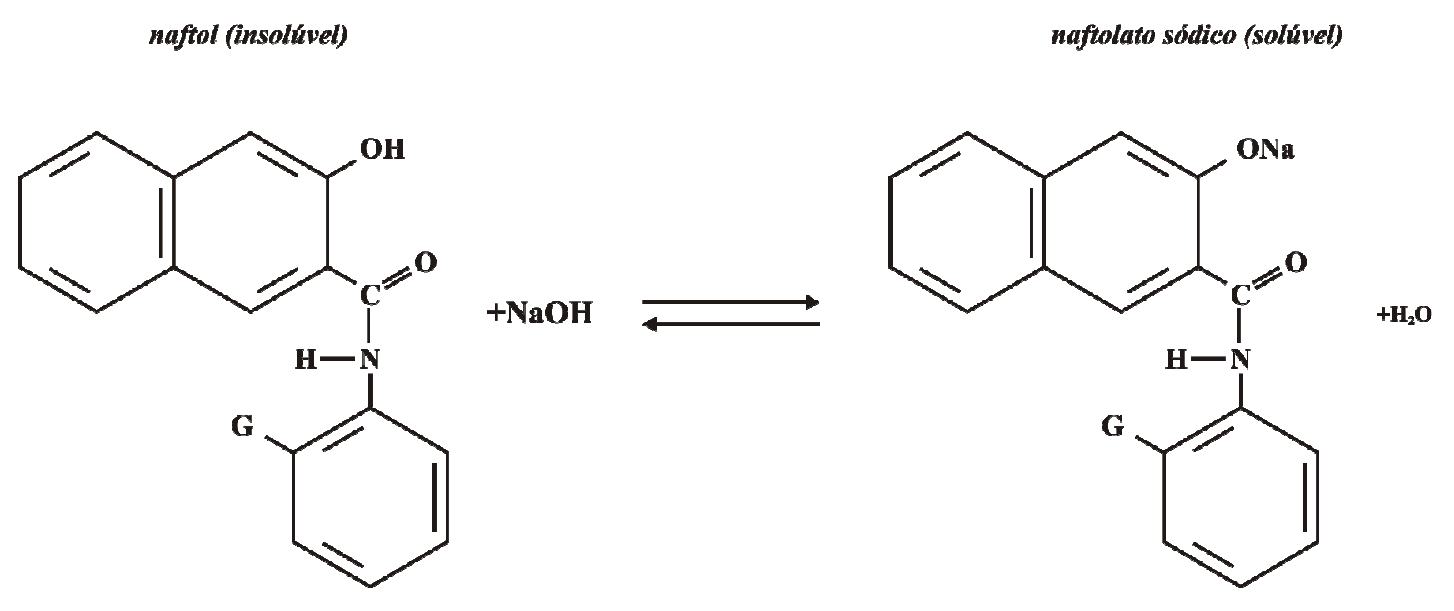

Figura 5 - Dissolução do naftolato de sódio (SILVA et al., 2011).<smiles>NOc1cc2ccccc2cc1C(N)=O</smiles>

sódio 3carbamoilnaftaleno-2-d ato
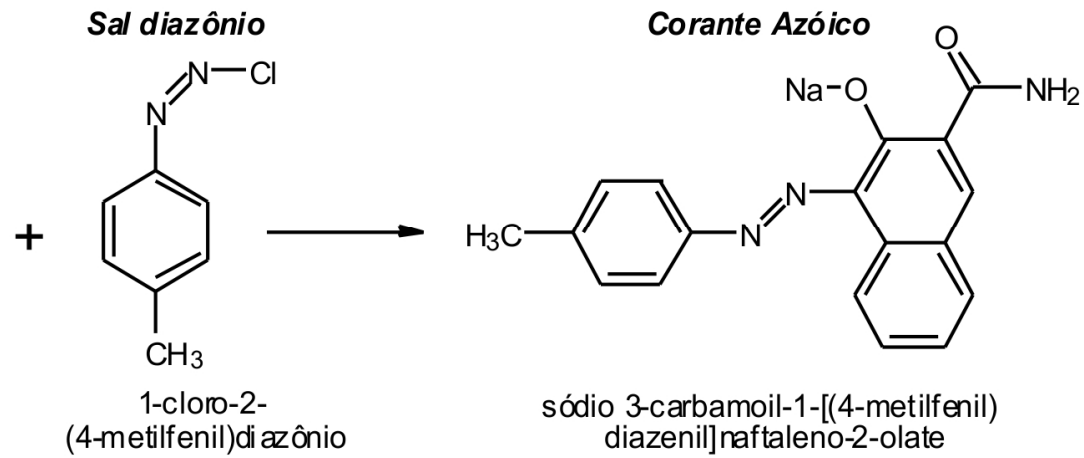

Figura 6 - Reação entre o naftolato sódico e o cloreto de sódio diazônio formando o corante azóico (SILVA et al., 2011). 


\section{Corantes reativos}

Constituem uma das classes de corantes mais utilizadas pela indústria têxtil, e tem um foco significativo dentro da indústria de confecção, uma vez que apresenta bons índices de solidez a lavagem e uma gama de cores vivas. Porém possui sensibilidade ao cloro e agride o meio ambiente, segundo Ciba ${ }^{1}$ (2001 apud MORAES, 2010), a utilização desta classe de corantes no Brasil corresponde a 57\% do mercado.

Utilizados para fibras celulósicas, sua molécula pode ser definida pelos seguintes sistemas estruturais: sistema cromóforo, que é responsável pela coloração, um grupo sulfonado, que será responsável pela solubilidade e caráter aniônico do corante e por último, um grupo reativo, que deve ser responsável pela formação da ligação fibra e corante por meio de ligação covalente, formando reações de adição ou substituição nucleofílica (Figuras 7 e 8 ).

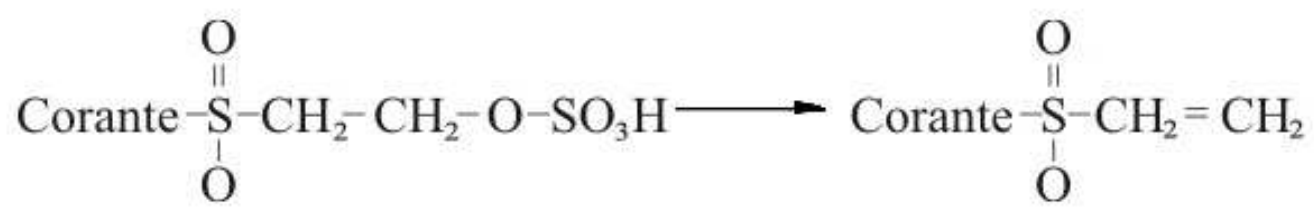

Figura 7 - Reação de adição nucleofílica (SALEM, 2010).

Esta classe de corante é dividida em função do seu grupo químico reativo, a reatividade de um corante é medida pela velocidade da reação em função da concentração de álcali e da temperatura. Quanto maior a concentração alcalina ou a temperatura que um corante necessita para reagir, menor a sua reatividade (BELTRAME, 2006). A Tabela 4 apresenta vários tipos de corantes reativos. Segundo Silva et al. (2011), os mais usados no mercado geralmente são o monoclorotriazina, o vinilsulfônico (VS) e os bifuncionais que possuem um grupo monoclorotriazina e outro vinilsulfônico na mesma molécula de corante.

\footnotetext{
${ }^{1}$ CIBA Brasil. Tendências Industriais, 2001
} 

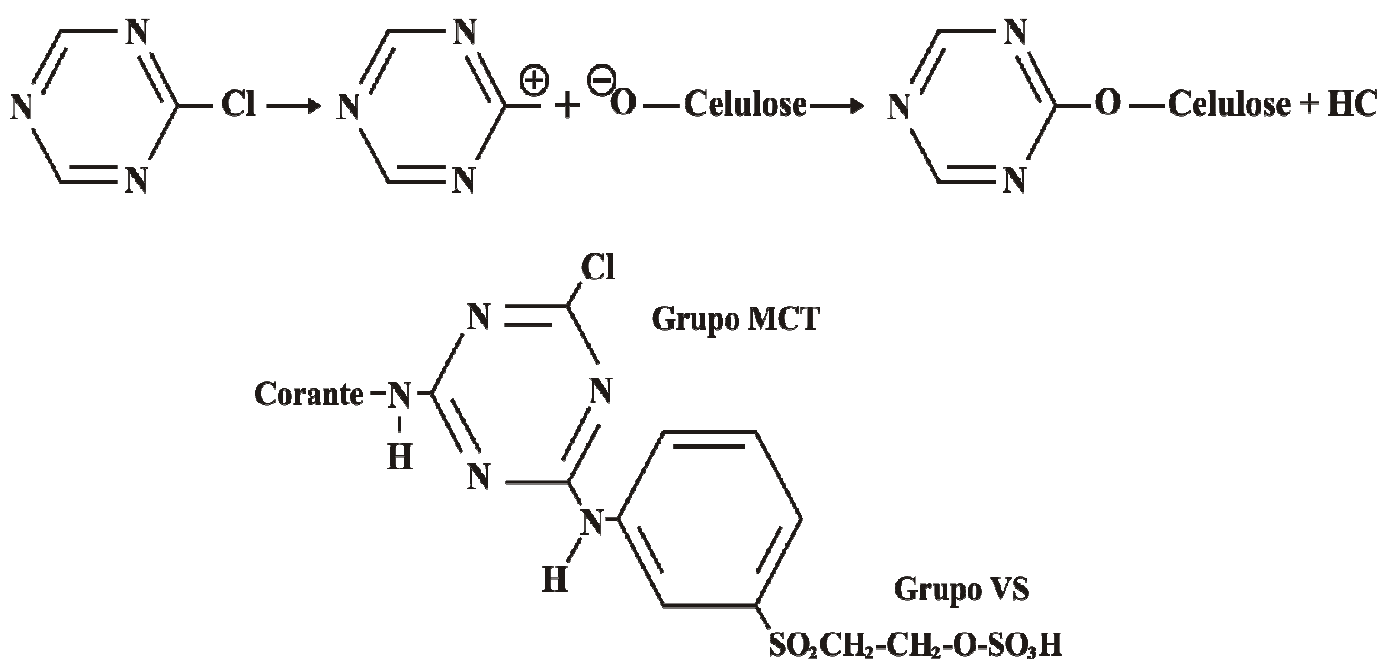

Figura 8 - Reação de substituição nucleofílica (SALEM, 2010).

Tabela 4 - Principais tipos de corantes reativos, por ordem decrescente de reatividade (SILVA et al., 2011).

\begin{tabular}{lcc}
\hline \multicolumn{1}{c}{ Grupo Reativo } & $\begin{array}{c}\text { Temperatura } \\
\text { tingimento em 으 }\end{array}$ & Reatividade \\
\hline Diclorotriazina (DCT) & $30-40$ & Alta \\
Difluorcloropirimidina (DFCP) & $40-60$ & Alta \\
Monofluortriazina (MFT) & $40-60$ & Alta \\
Vinilsulfônicos (VS) & $40-80$ & Média \\
Bi-heterofuncionais (VS+MCT) & $40-80$ & Média \\
Monoclorotriazina (MCT) & $80-100$ & Baixa \\
Tricloropirimidina (TCP) & $80-100$ & Baixa \\
\hline
\end{tabular}

A introdução de mais de um grupo reativo na estrutura da molécula do corante aumenta significativamente a fixação do corante no substrato têxtil, uma vez que mesmo que um grupo deste venha sofrer hidrólise, ou seja, reagir com a água, o outro tende a reagir com a celulose, estes são denominados corantes reativos bifuncionais (BELTRAME, 2006). 


\subsubsection{Colorimetria}

É a ciência responsável pela medição da cor, esta permite a transformação de um item subjetivo em cálculos matemáticos. Por meio da colorimetria é permitido a identificação, reprodução e padronização das cores (SILVA et al., 2013).

A cor, segundo Moraes (2010) é uma sensação, um aspecto de aparência, onde a sua percepção pode ser afetada por cores circundantes, ilusões de óptica e cansaço visual. É o trinômio formado por fonte de luz, objeto e observador.

Para se enxergar a cor são necessários três itens: a luz, o objeto a ser observado e o olho humano. Com o objetivo de padronizar a visualização da cor, A Commission Internationale de l'Éclairage (CIE) define varias fontes de luz e iluminantes para observação e comparação de cores, sendo a D65 a mais utilizada, pela sua temperatura da cor ser de 6500 Kelvin e ser semelhante a luz do dia (ALONSO, 2008).

Conforme Moraes (2010) A cor possui três características especificas: o matiz, a saturação e a intensidade.

- O matiz é fisicamente o intervalo de longitude de onda, onde pode se escrever uma determinada cor. Na prática, é a característica que faz com que, se possa reconhecer uma cor como sendo vermelha, outra como sendo azul;

- A saturação de uma cor é o seu grau de pureza. Uma cor é tanto mais saturada quanto menor for o seu conteúdo de branco e cinza. As cores da natureza são sempre mais ou menos saturadas. As cores mais saturadas são aquelas que não são originárias de pigmentos, mas sim de fenômenos interferências;

- A intensidade, ou luminosidade de uma cor é a característica que faz com que, ela apareça mais clara do que outra, independentemente de sua saturação.

Por meio dos valores encontrados nos diversos comprimentos de onda sobre a faixa do espectro do visível, é possível o cálculo de três valores triestímulos. (SILVA, 2013). Para este cálculo são necessários ter medido a reflectância $(R \lambda)$, 
assim duas cores podem ser consideradas iguais se os seu valores triestímulos forem iguais ou muito próximos, esta análise é chamada de diferença de cor, ou seja, $\Delta \mathrm{E}$, que significa a diferença de cor no espaço CIE $\mathrm{L}^{*} \mathrm{a}^{*} \mathrm{~b}^{*}$ e esta descrito como as coordenadas de espaços de cor conforme demonstra a equação $1(\Delta \mathrm{E})$ (HUERTAS et al.2006) .

$$
\Delta \mathrm{E}^{*}=\left[\left(\Delta \mathrm{L}^{*}\right)^{2}+\left(\Delta \mathrm{a}^{*}\right)^{2}+\left(\Delta \mathrm{b}^{*}\right)^{2}\right]^{1 / 2}
$$

$\Delta \mathrm{E}^{*}$ corresponde ao desvio total de cor;

$\Delta \mathrm{L}^{*}$ corresponde ao desvio no eixo da luminosidade;

$\Delta \mathrm{a}^{*}$ corresponde ao desvio no eixo "a", que identifica diferenças entre o verde e o vermelho;

$\Delta b^{*}$ corresponde ao desvio no eixo "b", que identifica diferenças entre o amarelo e o azul.

As Figuras 9 e 10 representam o espaço de Cor CIELAB.

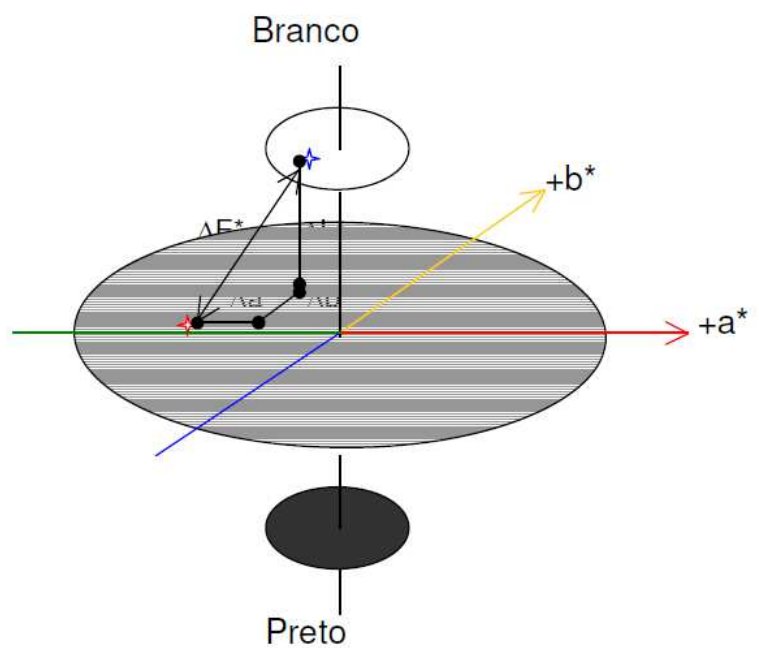

Figura 9- Espaço de cor CIELAB (GOUVEIA, 2004). 


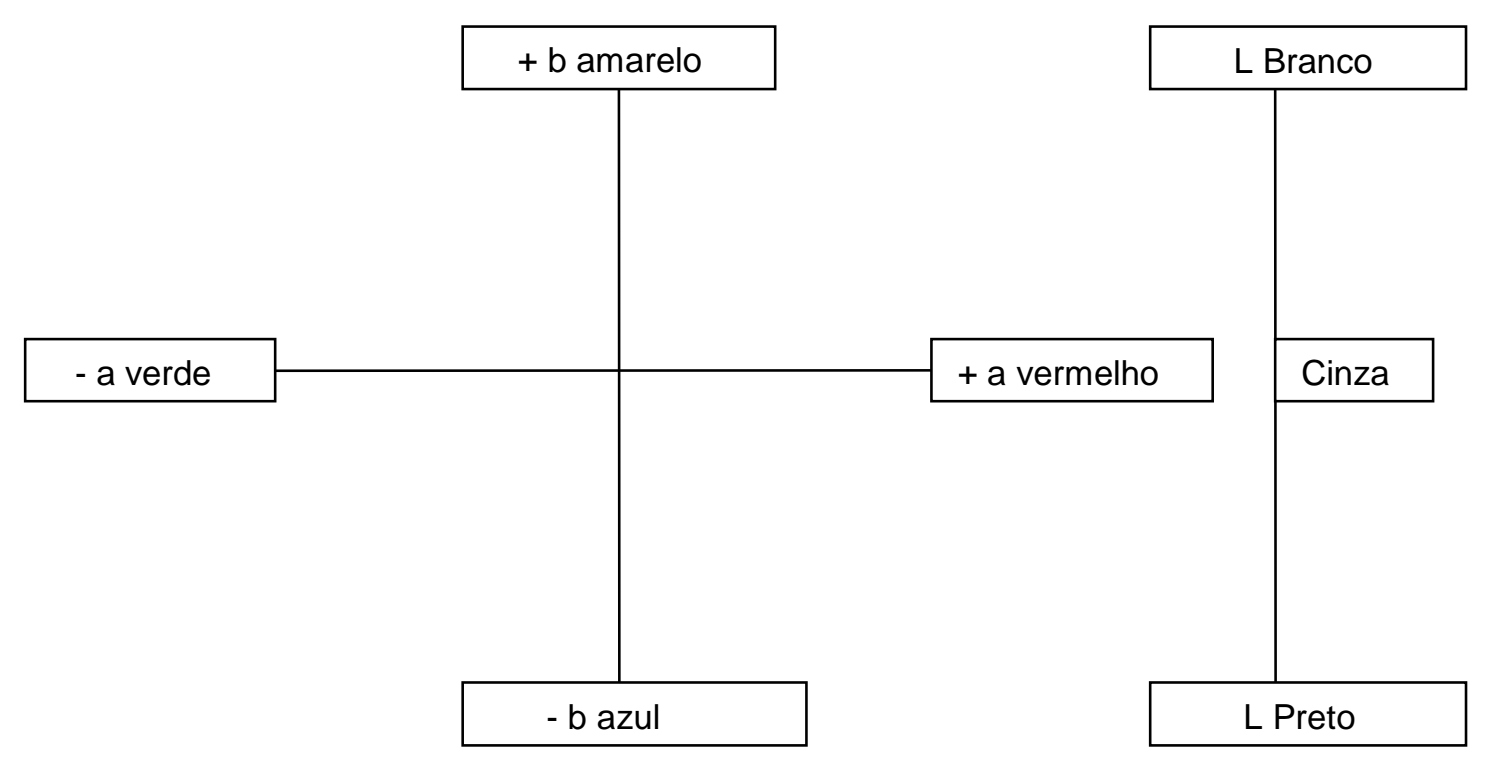

Figura 10 - Espaço de cor CIELAB (SILVA et al., 2011).

O Aparelho utilizado para leitura da cor é chamado espectrofotômetro. Estes analisam a cor na faixa do espectro do visível e medem a energia luminosa refletida e transmitida por uma dada amostra (SILVA et al. 2011; GOUVEIA, 2004).

O modelo matemático de cor CMC trata-se de um conjunto de equações matemáticas que foram desenvolvidas pelo Color Measurement Committee of the Society of Dyers and Colourists, baseada de acordo com as características de visão do olho humano (SENAI, 2013).

O sistema CMC 2:1 significa que a tolerância é duas vezes maior quando comparado à saturação e tonalidade, com isto tende a considerar a diferença de luminosidade sentida pelo olho humano. Este modelo permite que hajam elipsóides de sensibilidade que mudam de tamanho de acordo com a tonalidade da cor a ser analisada (Figura 11), através disto, faz com que a análise seja o mais próximo da realidade vista pelo olho humano (SENAI, 2013). 


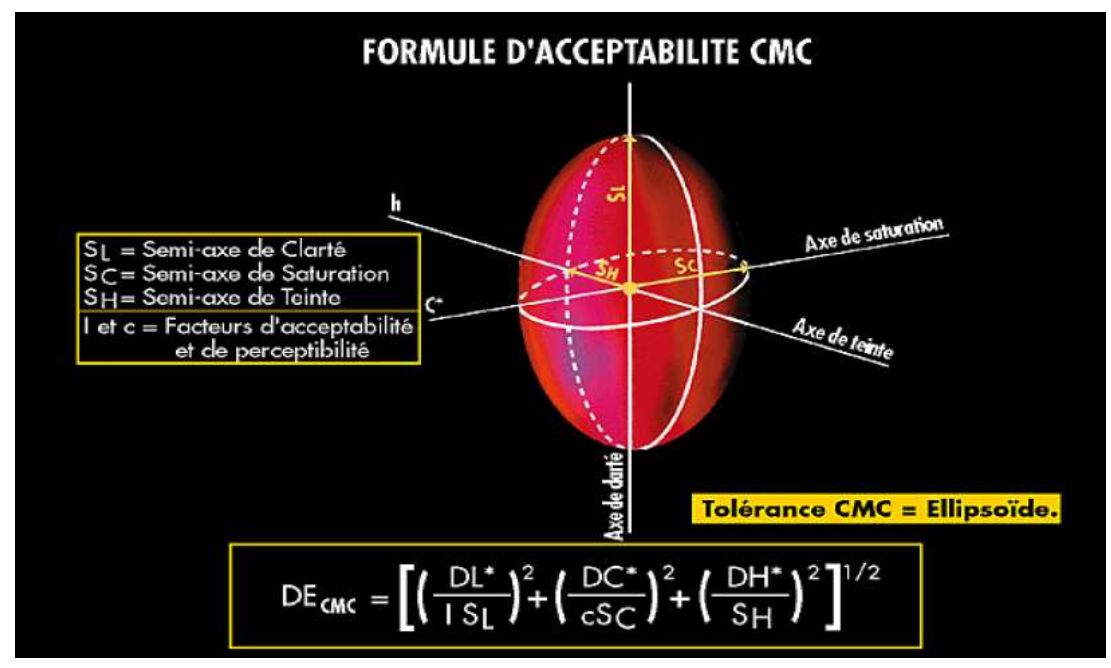

Figura 11 - Formula de aceitabilidade CMC (SENAI, 2004).

A diferença de cor aceitável dentro de uma indústria têxtil tende a variação conforme o segmento a que esta atende, se o segmento for automobilístico, por exemplo, os valores de $\Delta \mathrm{E}$ aceitáveis devem ser menores que 0,25 , ao passo que para indústria de confecção geralmente $\circ \Delta \mathrm{E}$ aceitável gira em torno de 0,8 a 1,2, sendo que o olho humano consegue identificar diferenças de cor a partir de 0,5.

\subsubsection{Ensaios de solidez a cor}

Tem por função fazer a análise da cor dos substratos têxteis buscando simular as condições pelas quais os tecidos serão submetidos durante o processo de produção e lou seu respectivo uso. As metodologias são baseadas em normas técnicas aplicáveis pelas:

- Associação Brasileira de Normas técnicas (ABNT);

- American Association of Textile Chemists and Colorists (AATCC);

- American Society for Testing nas Materials (ASTM);

- Deutsches Institut fur Normung e. V. (DIN);

- International Organization for Standardization (ISO); 
- Japanese Industrial Standards (JIS);

- Association Française de Normalisation (AFNOR).

\section{Ensaio de solidez da cor a lavagem}

Conforme a ABNT NBR ISO 105 - C06(2010), este ensaio tem a função de fazer a determinação da resistência da cor dos substratos têxteis aos processos de lavagens domésticas ou comerciais à que este será submetido posteriormente ao seu processo fabril. Conforme a norma, os ensaios são divididos em dois grupos:

- $\quad$ Simples: Simula uma lavagem comercial ou doméstica;

- $\quad$ Múltiplos: Simula uma lavagem em condições mais severas, aplicando ação mecânica e/ou temperatura.

\section{Ensaio de solidez da cor à luz}

Segundo ABNT NBR ISO 105 - B01(2009), este ensaio tem a função de avaliar a resistência da cor dos substratos têxteis a ação de uma fonte de luz artificial que tende a simular a ação da luz do dia.

O ensaio consiste em submeter o substrato têxtil a uma luz artificial sob determinadas condições juntamente com oito tecidos de lã azul que são considerados referência, após o processo, a análise é feita por meio de comparação da alteração ocorrida no mesmo e na respectiva escala.

\subsection{Processo industrial e tratamento de efluentes}

A Figura 12 demonstra o fluxo produtivo simplificado de uma tinturaria a qual tingem fibras de algodão, sintéticas e suas misturas, nele esta representada todos os pontos de emissões de efluentes, os quais são liberados no esgoto sanitário que é produzido pela mesma. 
A literatura consultada tem sido muito clara definindo a atual situação da indústria têxtil a respeito do controle da poluição da água, esta que se tornou um problema, em função do grande volume de efluente gerado, a diversidade de contaminantes diferentes com baixos índices de biodegradabilidade e a sua toxidade e sobre intensidade da cor que é o seu maior problema (KUNZ e PERALTAZAMORA, 2002; SALGADO et al., 2009; SANTANA, 2010). A Tabela 5, demonstra por classe de corantes os possíveis contaminantes lançados nos efluentes e a Tabela 6 mostra alguns valores estimados segundo Barreto (2006) para o percentual de corante fixado e o quanto pode ir para o efluente de acordo com a classe do corante.

A literatura consultada tem sido muito clara definindo a atual situação da indústria têxtil a respeito do controle da poluição da água, esta que se tornou um problema, uma vez que gera grandes volumes de efluentes, os quais normalmente possuem uma diversidade de contaminantes diferentes, com baixos índices de biodegradabilidade, toxidade e ainda com intensidade de cor, que é o seu maior problema (KUNZ e PERALTA-ZAMORA, 2002; SALGADO et al., 2009; SANTANA, 2010). A Tabela 5 , demonstra por classe de corantes os possíveis contaminantes lançados nos efluentes e a Tabela 6 mostra alguns valores estimados segundo Barreto (2006) para o percentual de corante fixado e o quanto pode ir para o efluente de acordo com a classe do corante. 


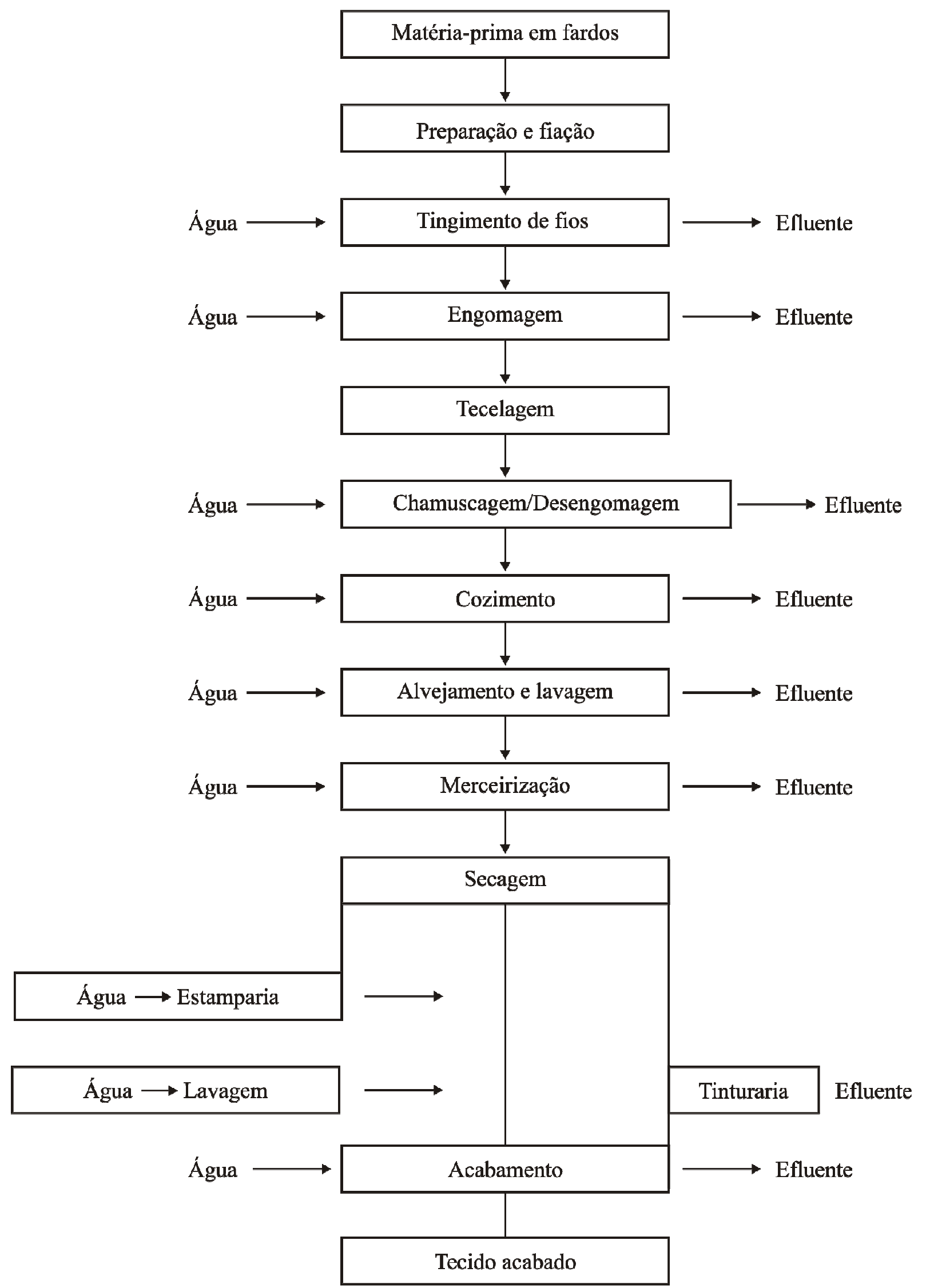

Figura 12 - Fluxograma do Processo de uma indústria têxtil (PERES e ABRAHÃO, 1998). 
Tabela 5 - Poluentes associados ao tingimento têxtil por classe de corante (ABRAÃO e SILVA, 2002).

\begin{tabular}{|c|c|c|c|c|}
\hline Corante & Descrição & Poluentes & Processo & Fibra \\
\hline Ácido & $\begin{array}{l}\text { Compostos } \\
\text { aniônicos } \\
\text { aplicados em } \\
\text { meio ácido } \\
\text { aquoso }\end{array}$ & $\begin{array}{l}\text { Ácidos orgânicos, } \\
\text { corantes por fixar. }\end{array}$ & $\begin{array}{l}\text { Esgotamento e } \\
\text { continuo }\end{array}$ & Nylon e lã \\
\hline Básico & $\begin{array}{c}\text { Compostos } \\
\text { catiônicos } \\
\text { solúveis em água }\end{array}$ & $\begin{array}{l}\text { Corantes por fixar, } \\
\text { cor, agentes } \\
\text { igualizantes. }\end{array}$ & Esgotamento & $\begin{array}{l}\text { Acrílica e } \\
\text { Poliéster }\end{array}$ \\
\hline Direto & $\begin{array}{l}\text { Compostos } \\
\text { aniônicos } \\
\text { solúveis em água }\end{array}$ & $\begin{array}{l}\text { Solventes, corantes } \\
\text { por fixar, cor, sais, } \\
\text { agentes fixadores } \\
\text { catiônicos, } \\
\text { surfactantes, } \\
\text { agentes } \\
\text { igualizantes, } \\
\text { produtos de } \\
\text { acabamentos. }\end{array}$ & $\begin{array}{l}\text { Esgotamento e } \\
\text { continuo }\end{array}$ & $\begin{array}{l}\text { Celulósica, } \\
\text { proteica e } \\
\text { poliamida. }\end{array}$ \\
\hline Disperso & $\begin{array}{l}\text { Compostos } \\
\text { insolúveis em } \\
\text { água usados em } \\
\text { solução aquosa }\end{array}$ & $\begin{array}{c}\text { Ácidos orgânicos, } \\
\text { carriers, solventes, } \\
\text { corantes por fixar, } \\
\text { cor, fosfatos, } \\
\text { lubrificantes, } \\
\text { dispersantes, } \\
\text { agentes } \\
\text { igualizantes, } \\
\text { produtos de } \\
\text { acabamento. }\end{array}$ & $\begin{array}{l}\text { Alta temperatura } \\
\text { esgotamento e } \\
\text { continuo }\end{array}$ & $\begin{array}{l}\text { Acrílica, } \\
\text { poliéster, } \\
\text { acetato, } \\
\text { triacetato e } \\
\text { poliamida. }\end{array}$ \\
\hline Reativo & $\begin{array}{l}\text { Compostos } \\
\text { aniônicos } \\
\text { solúveis em água } \\
\text { (classe mais } \\
\text { ampla) }\end{array}$ & $\begin{array}{l}\text { Solventes, cor, sais, } \\
\text { solução alcalina, } \\
\text { corantes por fixar, } \\
\text { surfactantes, } \\
\text { produtos de } \\
\text { acabamento. }\end{array}$ & $\begin{array}{c}\text { Esgotamento, } \\
\text { PAD-BATCH (frio) } \\
\text { / continuo. }\end{array}$ & $\begin{array}{l}\text { Celulósica, } \\
\text { proteica e } \\
\text { poliamida. }\end{array}$ \\
\hline Sulfuroso & $\begin{array}{l}\text { Compostos } \\
\text { orgânicos } \\
\text { contendo enxofre } \\
\text { ou sulfureto de } \\
\text { enxofre }\end{array}$ & $\begin{array}{l}\text { Cor, solução } \\
\text { alcalina, agentes } \\
\text { redutores e } \\
\text { oxidantes, cor por } \\
\text { fixar. }\end{array}$ & $\begin{array}{l}\text { Esgotamento e } \\
\text { continuo }\end{array}$ & Celulósica \\
\hline $\begin{array}{l}\text { Cuba ou } \\
\text { Tina }\end{array}$ & $\begin{array}{l}\text { Compostos } \\
\text { insolúveis em } \\
\text { água }\end{array}$ & $\begin{array}{l}\text { Cor, solução } \\
\text { alcalina, agentes } \\
\text { redutores e } \\
\text { oxidantes, cor por } \\
\text { fixar. }\end{array}$ & $\begin{array}{l}\text { Esgotamento e } \\
\text { continuo }\end{array}$ & $\begin{array}{c}\text { Proteica (La e } \\
\text { Seda) } \\
\text { celulósica }\end{array}$ \\
\hline
\end{tabular}


Tabela 6 - Estimativa do grau de fixação dos diferentes corantes nas fibras têxteis e perdas para o efluente, permitidos pela sociedade de corantes e colorações (BARRETO, 2006 adaptado pela autora).

\begin{tabular}{lcc}
\hline $\begin{array}{l}\text { Classe de aplicação } \\
\text { dos corantes }\end{array}$ & Grau de fixação (\%) & Perda para o efluente (\%) \\
\hline Ácidos & $89-95$ & $5-11$ \\
Complexo metálicos & $95-98$ & $2-5$ \\
Básicos & $70-95$ & $5-30$ \\
Disperso & $90-98$ & $2-10$ \\
Diretos & $90-98$ & $2-10$ \\
Reativo & $50-90$ & $10-50$ \\
Sulfuroso & $60-90$ & $10-40$ \\
Tina & $80-95$ & $5-20$ \\
\hline
\end{tabular}

A análise de remoção de cor pode ser avaliada por meio de técnicas espectrofotométricas conforme a literatura tem definido (GUARATINI E ZANONI, 2000; ARAUJO e YOKOYAMA, 2006), estas permitem que sejam feitas análises comparativas entre os efluentes brutos e os efluentes tratados por POAs (ROSA, 2010).

Normalmente são considerados como grupo de maior toxidade aqueles que possuem o grupo químico azoaromático na função de cromóforo, a maioria dos corantes têxteis o possui. Estes tendem a sofrer biotransformações e se transformar em outros produtos com um grau de toxidade maior. Estas biotransformações podem ser provocadas por alguns mecanismos tais como processos de oxidação, redução, hidrólise e conjugação. Em função da solubilidade, seguem normalmente um metabolismo centrado em processo de redução transformando a amina aromática que é clivada e gerando apenas a ligação -N=N- (SOUZA, 2006).

A questão toxicológica no que tange aos corantes têxteis relaciona-se ao modo e tempo de exposição, ingestão oral, sensibilização da pele e das vias 
respiratórias. A toxidade oral dos mesmos é medida por meio de $50 \%$ da dose letal $\left(\mathrm{LD}_{50}\right)$ e tem mostrado que somente alguns corantes apresentam toxidade alta $\left(\mathrm{LD}_{50} \angle 5 \mathrm{~g} / \mathrm{Kg}\right.$ ) e são características dos corantes bis-azo e catiônicos (GUARATINI E ZANONI, 1999).

Os métodos convencionais utilizados para o tratamento de efluentes líquidos industriais normalmente são classificados em primários ou mecânicos, secundários ou biológicos e terciários ou físico-químicos e constituem aqueles empregados nas indústrias têxteis. A Tabela 7 resume as opções existentes para cada tipo.

Tabela 7 - Processos de tratamento de efluentes (PERES e ABRAÃO, 1998).

\section{Tratamento Tipo de processo Operação unitária}

Primário

Terciário

Avançado
Físico

Equalização, gradeamento, clarificação/sedimentação e flotação.

Químico

Neutralização e coagulação/precipitação.
Secundário

Biológico

Físico/químico e

químico

Físico

Físico
Lodos ativados, lagoa de esterilização e

filtros biológicos.

Carvão ativado, coagulação/precipitação, ozonização e cloração Clarificação (carvão ativado) e ultrafiltração Osmose reversa e evaporação. 
O efluente gerado na tinturaria compõe diversos compostos orgânicos que apenas os tratamentos físico-químicos e os biológicos não são suficientes (CATANHO et al. 2006; ALVES, 2010).

Existem vários métodos de tratamento para águas residuárias têxteis, porém se usados isoladamente, não são suficientes para o cumprimento da legislação, por exemplo, o processo de coagulação se mostra eficiente na remoção de corantes insolúveis, tais como dispersos, ao passo que com corantes reativos que são solúveis em água, este processo não é interessante. É importante também comentar que este processo gera uma quantidade de precipitado que é um resíduo que também tem que ter a destinação adequada e representa custo ao processo (GUARANTINI e ZANONI, 2000; TEIXEIRA et al., 2004; HASSEMER et al., 2012).

\subsubsection{Processos oxidativos avançados}

Em função da variação de composição dos efluentes têxteis, a dificuldade de remoção e degradação dos corantes presentes nos mesmos por sistema de tratamentos convencionais torna-se necessário buscar novas tecnologias alternativas que facilitem a degradação dos corantes (CLAUSEN e TAKASHIMA, 2007). Os "Processos Oxidativos Avançados (POAs)" tem sido apresentado pela literatura como uma inovação devido a sua eficiência quando se trata da destruição de compostos tóxicos e recalcitrantes (ARAUJO E YOKOYAMA, 2006).

Segundo Hassemer (2006), os POAs são caracterizados por formar radicais hidroxila, $\mathrm{HO} \bullet$, um agente com elevado poder oxidante $\left(E^{\circ}=2,3 \mathrm{~V}\right)$, extremamente reativo e de reduzida seletividade, capaz de atuar sobre uma grande diversidade de poluente orgânicos. Estes radicais são formados pela estimulação de oxidantes fortes tais como, por exemplo, peróxido de hidrogênio $\left(\mathrm{H}_{2} \mathrm{O}_{2}\right)$, ozônio $\left(\mathrm{O}_{3}\right)$ ou semicondutores como o óxido de titânio $\left(\mathrm{TiO}_{2}\right)$, o óxido férrico $\left(\mathrm{Fe}_{2} \mathrm{O}_{3}\right)$, o óxido de zinco $(\mathrm{ZnO})$ e o óxido de alumínio $\left(\mathrm{Al}_{2} \mathrm{O}_{3}\right)$, dentre outros (AZEVEDO et al., 2010).

Um método direto para geração de $\mathrm{HO} \bullet$ é a fotoclivagem do peróxido de hidrogênio por meio de radiação UV. $\mathrm{O}$ processo de $\mathrm{H}_{2} \mathrm{O}_{2} / \mathrm{UV}$ pode levar a degradação completa e a conversão à dióxido de carbono $\left(\mathrm{CO}_{2}\right)$ e água $\left(\mathrm{H}_{2} \mathrm{O}\right)$ e sais 
inorgânicos da maioria dos contaminantes orgânicos (ARAUJO e YOKOYAMA, 2006).

\section{Peróxido de hidrogênio $\left(\mathrm{H}_{2} \mathrm{O}_{2}\right)$}

O peróxido de hidrogênio é um líquido incolor, límpido, de baixa viscosidade, possui aparência da água. Comercializado em concentrações que variam de 27,5\% a 70\%. Não inflamável, corrosivo, miscível em água em qualquer proporção e de toxidade mediana, pois a LDL (do inglês lethal dose low, ou seja, a dose mais baixa de substância capaz de provocar morte) é de $1429 \mathrm{mg} \mathrm{Kg}^{-1}$ para seres humanos. Muito utilizado como oxidante ambientalmente correto, pois o resultado da sua decomposição nada mais é que oxigênio e calor. Durante o processo de fabricação são usados alguns estabilizadores para inibir a decomposição provocada por metais e luz ultravioleta (VOLOSHIN et al., 2007).

Segundo a US PEROXIDE (2013), o peróxido tem sido usado para reduzir Demanda Biológica de Oxigênio $(D B O)$ e a Demanda Química de Oxigênio (DQO) de águas residuárias industriais há muitos anos, embora o custo da remoção de DBO e DQO por oxidação química seja tipicamente maior do que por métodos físicos ou biológicos, existem situações específicas segundo Araújo (2002) que justificam o seu uso, as quais incluem:

- $\quad$ Pré-digestão de águas residuárias que contenham nível moderado a alto de compostos tóxicos, inibidores ou recalcitrantes para tratamento biológico como, por exemplo, pesticidas, resinas, fluidos refrigerantes e corantes;

- $\quad$ Pré-tratamento de águas residuárias com elevadas ou muito baixas vazões;

- Intensificação da separação de orgânicos em processo de flotação e sedimentação;

- $\quad$ Suplemento de oxigênio dissolvido (OD) quando ocorre sobrecarga temporária ou falha de equipamentos em sistemas de tratamento biológico. 
Desta forma, o peróxido de hidrogênio pode ser usado como um processo individual, ou em conjunto com outros processos físicos ou biológicos existentes.

Através da catálise, este é transformado em radical hidroxila $(\cdot \mathrm{OH})$. Segundo Mattos et al. (2003), além de ser considerado um agente oxidante, como demonstrado na reação (1), este pode também ser um redutor como demonstrado na reação (2).

$$
\begin{aligned}
& \mathrm{H}_{2} \mathrm{O}_{2}+2 \mathrm{H}^{+}+2 \mathrm{e}^{-} \rightarrow 2 \mathrm{H}_{2} \mathrm{O} \quad 1,77 \mathrm{~V}(1) \\
& \mathrm{H}_{2} \mathrm{O}_{2}+2 \mathrm{OH} \longrightarrow \mathrm{O}_{2}+\mathrm{H}_{2} \mathrm{O}+2 \mathrm{e}^{-} \quad-0,15 \mathrm{~V} \quad \text { (2) }
\end{aligned}
$$

\section{Oxidação fotoquímica}

Entende-se por qualquer reação química provocada pela absorção de radiação ultravioleta, quer seja no visível ou no infravermelho (HASSEMER, 2006).

Segundo Hassemer (2006), a oxidação fotoquímica pode ocorrer pelos seguintes processos:

- Perda de um ou mais elétrons de uma espécie química como resultado da sua foto-excitação;

- Reação de uma substância com oxigênio, sob a influência de radiação. Se o oxigênio permanece como parte do produto este processo também se pode denominar foto-oxigenação. Reações em que o oxigênio é levado a níveis eletrônicos excitados, são designadas por reações de oxidação foto iniciadas.

A oxidação fotoquímica do peróxido de hidrogênio pela radiação UV gera dois radicais hidroxila (reação 3), que agem degradando a matéria orgânica e formando compostos mais simples (reação 4). Quando o peróxido de hidrogênio está em excesso pode ocorrer uma reação paralela, que diminui a reação de degradação da 
matéria orgânica (reação 5), isto se dá porque este age capturando os radicais hidroxilas (ARAUJO e YOKOYAMA, 2006).

$$
\begin{gathered}
\mathrm{H}_{2} \mathrm{O}_{2} \stackrel{\mathrm{hv}}{\longrightarrow} 2 \mathrm{HO} \bullet(3) \\
\mathrm{R}-\mathrm{H}+\mathrm{HO} \bullet \longrightarrow \text { Produtos finais }\left(\mathrm{CO}_{2}, \mathrm{H}_{2} \mathrm{O}, \mathrm{NO}_{3}^{-}, \mathrm{CL}^{-}\right)(4) \\
\mathrm{HO} \bullet+\mathrm{H}_{2} \mathrm{O}_{2} \longrightarrow \mathrm{HO}_{2} \bullet+\mathrm{H}_{2} \mathrm{O} \text { (5) }
\end{gathered}
$$

Segundo SLOKAR e LE MARECHAL (1998), os principais fatores que influenciam o processo $\mathrm{H}_{2} \mathrm{O}_{2} / \mathrm{UV}$ em águas residuais têxteis são a concentração do peróxido de hidrogênio, a intensidade da radiação ultravioleta, o $\mathrm{pH}$, a estrutura do corante e a composição do efluente.

\subsection{Poluição provocada pela indústria têxtil e o meio ambiente}

No que se refere ao consumo da indústria, o setor têxtil consome aproximadamente $15 \%$ da água. O potencial contaminante da indústria têxtil, em sua totalidade, é considerado médio, sendo que os setores de tinturaria e acabamento são conhecidos pelo seu alto potencial poluidor, uma vez se comparadas com a fiação e a tecelagem (TOLEDO, 2004).

A Tabela 8 mostra uma média da quantidade de água utilizada na área têxtil em função do quilo de substrato têxtil, ou seja, este pode ser considerado desde fibra até o tecido.

A legislação brasileira no tocante à proteção ambiental é composta por muitas leis, porém estas apresentam muitas falhas, algumas destas ainda são muito antigas e com isto, dificulta muito a fiscalização (VAINER, 2007).

A lei n. ${ }^{\circ} 6938 / 81$, art. 3, III o termo poluição é definido como "a degradação da qualidade ambiental resultante de atividade que direta ou indiretamente":
a) Prejudiquem a saúde, a segurança e o bem-estar da população;
b) Criem condições adversas às atividades sociais e econômicas; 
c) Afetem desfavoravelmente a biota;

d) Afetem as condições estéticas ou sanitárias do meio ambiente;

e) Lancem matérias ou energia em desacordo com os padrões ambientais estabelecidos.

Tabela 8 - Consumo de água em função do substrato (CPRH, 2001).

\section{Consumo de água em $\mathrm{L} / \mathrm{Kg}$}

\begin{tabular}{lccc}
\hline \multicolumn{1}{c}{ Processos } & Mínimo & Médio & Máximo \\
Lã - lavagem & 40,2 & 11,7 & 77,5 \\
Lã - acabamento & 110,9 & 283,6 & 657,2 \\
& Tecidos planos & & \\
Processo simples & 12,5 & 78,4 & 275,2 \\
Processo complexo & 10,8 & 86,7 & 276,9 \\
Processo complexo + & 5,0 & 113,4 & 507,9 \\
desengomagem & & & \\
& Tecido de malha & & \\
Processo simples & 8,3 & 135,9 & 392,8 \\
Processo complexo & 20,0 & 83,4 & 377,8 \\
Meias & 5,8 & 69,2 & 289,4 \\
Carpetes & 8,3 & 46,7 & 162,6 \\
Fios acabamentos & 3,3 & 100,1 & 557,1 \\
Não tecidos & 2,5 & 40,0 & 82,6 \\
Feltrados & 33,4 & 212,7 & 930,7 \\
\hline
\end{tabular}


A poluição provocada pela indústria é indiscutível, uma vez que, durante o processo produtivo é impossível se ter um rendimento do mecanismo de reação da ordem de $100 \%$, por mais que existam controles minuciosos de processo e mesmo utilizando ferramentas de produção mais limpa. Outra questão a ser citada também é o fato de que o acúmulo de matérias-primas e insumos, que envolvem sérios riscos de contaminação por transporte ou disposição inadequada, ou ainda a ineficiência dos processos de conversão, o que necessariamente implica na geração de resíduos (FREIRE et al., 2000).

A legislação tem contribuído muito em busca de um fim comum, que seria a diminuição de poluentes dentro de um processo industrial. Atualmente se têm desenvolvido muitas pesquisas com objetivo de remover a cor dos efluentes produzidos pelas indústrias têxteis, para que se torne possível o descarte nos corpos receptores ou ainda destinar esta água tratada a um reuso não potável (KUNZ E PERALTA-ZAMORA, 2002).

Como as atuais projeções a respeito da disponibilidade de água e a comprovação da toxidade proveniente dos efluentes industriais, isto obrigou a legislação se tornar mais restritiva, evoluindo incessantemente no estabelecimento de padrões específicos para o enquadramento de corpos de água, assim como de padrões para o lançamento de efluentes, na última década surgiram duas Resoluções CONAMA, a 357/2005 e a 396/2008 (ZANELLA et al., 2010).

Os padrões de lançamento de efluentes líquidos refere-se as concentrações máximas de poluentes aceitáveis nos esgotos industriais e estações de tratamento de esgoto antes da sua entrada nos corpos d'água, são definidos a nível federal, pelo Conselho Nacional de Meio Ambiente. Contrapartida as legislações estaduais e municipais podem se tornar ainda mais restritivas em função dos problemas ambientais existentes na dada região, porém, isto não pode vir a ser inconstitucional, ou seja, não pode revogar a legislação ambiental federal inferiorizando determinados padrões.

O grau de toxidade representados pelos corantes são inquestionáveis atualmente, mas além disto, possuem ainda, um grande agravante, eles são facilmente detectáveis a olho nu, sendo normalmente visíveis em concentrações tão baixas, quanto $1 \mathrm{ppm}$. Com isto, uma pequena quantidade lançada nos corpos de 
água tende a modificar a coloração dos rios, mas que em contrapartida também é facilmente detectada pelos órgãos de controle ambiental (GUARANTINI e ZANONI, 2000).

$\mathrm{Na}$ Resolução CONAMA nْ 357, não existem restrições específicas para concentração de corantes nos efluentes, mas determina que sua descarga não possa provocar coloração nos corpos receptores (SILVA, 2011; SANTOS et al., 2012; RIBEIRO et al., 2012).

\subsubsection{Evolução da legislação ambiental}

Em 1934 surgiu o Código das Águas, Decreto № 24.643, embora tenha tramitado no congresso desde 1907 , foi o primeiro decreto específico que prioriza os recursos hídricos, através da determinação das regras para sua utilização com fins energéticos e ainda define a água como bem público (HASSEMER, 2006).

$\mathrm{Na}$ década de 40 foram criadas instituições que emitiam autorização para utilização da água para fins industriais, a intensificação das preocupações da sociedade com a poluição industrial alcançou a escala nacional no início da década de 70, na esteira do "Milagre Brasileiro", onde foi criado a Secretaria Especial do Meio Ambiente (SEMA) no ano de 1971 (ALMEIDA et al., 2004).

Em relação ao controle das cargas poluidoras dos efluentes industriais foi regulamentada a portaria GM 0013, de 15/01/1976, onde seu detalhamento veio por meio da Resolução CONAMA №20, de 18/06/1986, esta veio definir uma classificação das águas territoriais.

O CONAMA aprovou uma nova versão que é de $n^{\circ} 357$ em 17/03/2005, mais restritiva, onde determina as condições de qualidade da água e classifica os corpos hídricos segundo esta, as condições que podem ser relacionadas ao lançamento de efluentes têxteis são:

- Os efluentes de qualquer fonte poluidora somente poderão ser lançados, direta ou indiretamente, nos corpos de água, após o devido tratamento e desde que obedeçam às condições, padrões e exigências dispostos nesta Resolução e em outras normas aplicáveis; 
- Nas águas de classe especial é vedado o lançamento de efluentes industriais, mesmo que tratados;

- Nas demais classes de água, o lançamento de efluentes deverá, simultaneamente: atender às condições e padrões de lançamento de efluentes, e não ocasionar a ultrapassagem das condições e padrões de lançamento de efluentes, e não ocasionar a ultrapassagem das condições e padrões de qualidade de água estabelecidos para as respectivas classes;

- O efluente não deverá causar ou possuir potencial para causar efeitos tóxicos aos organismos aquáticos no corpo receptor, de acordo com os critérios de toxicidade estabelecidos pelo órgão ambiental competente. Os critérios de toxicidade devem-se basear em resultados ecotoxicológicos padronizados, utilizando organismos aquáticos, e realizados no efluente;

- Para lançamentos em águas doces (salinidade igual ou inferior a 0,50\%): na classe II não será permitida presença de corantes artificiais que não possam ser eliminados por coagulação, sedimentação e filtração convencional (cor $\leq 75 \mathrm{mg} / \mathrm{L} \mathrm{Pt}$ ); na classe III a cor deve ser menor ou igual a $75 \mathrm{mg} / \mathrm{L} \mathrm{Pt}$.

Fazendo um comparativo da legislação estadual da cidade de São Paulo que é regida pelo Decreto $N^{\circ} 8468$ de 08/09/1976, porém esta vai de encontro com a Resolução CONAMA №357/2005, mas fazendo apenas pequenas alterações, os limites de padrões de lançamentos são demonstrados na Tabela 9.

Embora a resolução CONAMA № 357/05, não determina limites de cor para lançamentos de efluentes, isto se tornou fator preponderante para que o impacto ambiental ocasionado pelo lançamento de efluentes com altos níveis de coloração fosse relevado, esta era considerada apenas como caráter visual e estético, mas se for feito uma análise mais crítica da legislação, esta cria limites para cor através dos parâmetros de qualidade para classificação das águas, definindo ainda, que nenhum efluente pode ser lançado para que modifique as suas características de qualidade (SANTOS et al., 2012). 
Tabela 9 - Estudo comparativo dos parâmetros de lançamento da Resolução CONAMA №357/2005 e Decreto No $8468 / 76$.

\begin{tabular}{|c|c|c|c|c|}
\hline Parâmetro & Unidade & $\begin{array}{l}\text { Resolução CONAMA } \\
\text { №357 de 17/03/2005 }\end{array}$ & $\begin{array}{c}\text { Decreto } N^{\circ} 8468 \\
\text { de } 08 / 09 / 1976 \\
\text { artigo } 18\end{array}$ & $\begin{array}{c}\text { Decreto } N^{\circ} 8468 \\
\text { de } 08 / 09 / 1976 \\
\text { artigo } 19 \mathrm{~A}\end{array}$ \\
\hline $\mathrm{pH}$ & - & Entre 5 e 9 & Entre 5 e 9 & Entre 6 e 10 \\
\hline Temperatura & ${ }^{\circ} \mathrm{C}$ & Inferior a 40 & Inferior a 40 & Inferior a 40 \\
\hline Materiais Sedimentáveis & $\mathrm{mg} / \mathrm{L}$ & 1,0 & 1,0 & 20,0 \\
\hline Óleos Minerais & $\mathrm{mg} / \mathrm{L}$ & 20 & - & \\
\hline Óleos Vegetais e Gorduras Animais & $\mathrm{mg} / \mathrm{L}$ & 50 & - & - \\
\hline Materiais Flutuantes & $\mathrm{mg} / \mathrm{L}$ & Ausência & - & - \\
\hline DBO & $\mathrm{mg} / \mathrm{L}$ & & 60,0 & 60,0 \\
\hline Substancias Solúveis em Hexana & $\mathrm{mg} / \mathrm{L}$ & - & - & 150,0 \\
\hline Arsênio Total & $\mathrm{mg} / \mathrm{L}$ & 0,5 & 0,2 & 1,5 \\
\hline Bário Total & $\mathrm{mg} / \mathrm{L}$ & 5,0 & 5,0 & \\
\hline Boro Total & $\mathrm{mg} / \mathrm{L}$ & 5,0 & 5,0 & 5,0 \\
\hline Cádmio Total & $\mathrm{mg} / \mathrm{L}$ & 0,2 & 0,2 & 1,5 \\
\hline Chumbo Total & $\mathrm{mg} / \mathrm{L}$ & 0,5 & 0,5 & 1,5 \\
\hline Cianeto Total & $\mathrm{mg} / \mathrm{L}$ & 0,2 & 0,2 & 0,2 \\
\hline Cobre Total & $\mathrm{mg} / \mathrm{L}$ & 1,0 & 1,0 & 1,5 \\
\hline Cromo Total & $\mathrm{mg} / \mathrm{L}$ & 0,5 & 5,0 & 5,0 \\
\hline Estanho Total & $\mathrm{mg} / \mathrm{L}$ & 4,0 & 4,0 & 4,0 \\
\hline Ferro Dissolvido & $\mathrm{mg} / \mathrm{L}$ & 15,0 & 15,0 & 15,0 \\
\hline Fluoreto Total & $\mathrm{mg} / \mathrm{L}$ & 10,0 & 10,0 & 10,0 \\
\hline Manganês Dissolvido & $\mathrm{mg} / \mathrm{L}$ & 1,0 & 1,0 & \\
\hline Mercúrio Total & $\mathrm{mg} / \mathrm{L}$ & 0,01 & 0,01 & 1,5 \\
\hline Níquel Total & $\mathrm{mg} / \mathrm{L}$ & 2,0 & 2,0 & 2,0 \\
\hline Nitrogênio Amoniacal Total & $\mathrm{mg} / \mathrm{L}$ & 20,0 & & \\
\hline Prata Total & $\mathrm{mg} / \mathrm{L}$ & 0,1 & 0,02 & 1,5 \\
\hline Selênio Total & $\mathrm{mg} / \mathrm{L}$ & 0,30 & 0,02 & 1,5 \\
\hline Sulfeto & $\mathrm{mg} / \mathrm{L}$ & 1,0 & & 1,0 \\
\hline Zinco Total & $\mathrm{mg} / \mathrm{L}$ & 5,0 & 5,0 & 5,0 \\
\hline Clorofórmio & $\mathrm{mg} / \mathrm{L}$ & 1,0 & & \\
\hline Dicloroetano & $\mathrm{mg} / \mathrm{L}$ & 1,0 & & \\
\hline Fenóis Totais & $\mathrm{mg} / \mathrm{L}$ & 0,5 & & \\
\hline Tetracloreto de Carbono & $\mathrm{mg} / \mathrm{L}$ & 1,0 & & \\
\hline Tricloetano & $\mathrm{mg} / \mathrm{L}$ & 1,0 & & \\
\hline
\end{tabular}


Embora a resolução CONAMA № 357/05, não determina limites de cor para lançamentos de efluentes, isto se tornou fator preponderante para que o impacto ambiental ocasionado pelo lançamento de efluentes com altos níveis de coloração fosse relevado, esta era considerada apenas como caráter visual e estético, mas se for feito uma análise mais crítica da legislação, esta cria limites para cor através dos parâmetros de qualidade para classificação das águas, definindo ainda, que nenhum efluente pode ser lançado para que modifique as suas características de qualidade (SANTOS et al., 2012). 


\section{OBJETIVOS}

O objetivo geral deste trabalho foi o tratamento de efluente por processo de oxidação avançada $\mathrm{H}_{2} \mathrm{O}_{2} / \mathrm{UV}$. Os efluentes têxteis tintos com corantes reativos foram produzidos em laboratório segundo as condições de processos industriais e foram utilizados nos estudos de reuso em um novo processo de tingimento.

Para atingirmos o objetivo principal foram propostos os seguintes objetivos específicos:

- $\quad$ Estabelecer uma tricromia básica (três corantes que juntos permitem o desenvolvimento de qualquer cor);

- $\quad$ Estabelecer o processo para o tratamento do efluente no reator com lâmpada ultravioleta utilizando peróxido de hidrogênio a 200 Volumes;

- Determinar os parâmetros de tratamento $(\mathrm{pH}$, temperatura e concentração de peróxido de hidrogênio;

- Determinar a qualidade das amostras tingidas através da comparação com os padrões conforme os aceitáveis no mercado;

- Realizar de modo cíclico o processo de tingimento, buscando manter os mesmos parâmetros de processos utilizados para o tingimento do padrão;

- Estudar o limite de saturação dos efluentes para o reuso durante os processos de tingimentos. 


\section{MATERIAIS E MÉTODOS}

Neste tópico foi descrito todos os reagentes e equipamentos utilizados para o desenvolvimento deste trabalho.

\subsection{Materiais}

Hidróxido de sódio, carbonato de sódio, cloreto de sódio comercial fornecidos pela Cromoline; agente sequestrante de cálcio e magnésio comercial chamado Ladiquest, corantes amarelo Drimaren CL-2R; vermelho Drimaren CL-5B, e azul Drimaren HF-RL fornecidos pela Clariant $S / A$; peróxido de hidrogênio de grau analítico da Vetec (concentração: 200 Volumes ou 50\%); ácido acético de grau analítico da Cromoline (concentração: 98\%) e a enzima catalase (nome comercial Goldzima HPX) fornecido pela Golden Química do Brasil.

\section{Equipamentos}

Os equipamentos utilizados para realização deste trabalho foram: Máquina de Tingimento de alta temperatura da marca Mathis modelo ALT-B; centrifuga da marca USUI; balança analítica da marca Gehaka; estufa de Laboratório da marca Quimis; espectrofotômetro de bancada da marca Kônica Minolta CM-3600; reator com três lâmpadas UV (253,7 nm) de 6 W cada; agitador Magnético da marca Quimis; pHmetro da marca Tecnal modelo TEC - 3MP; condutivímetro da marca Tecnal modelo TEC - 3MP; espectrofotômetro UV visível Beckman Du 640.

Para os ensaios de degradação fotoquímica, foi utilizado um reator, com capacidade de tratamento de até $2000 \mathrm{~mL}$, atuando por batelada (Figura 13). Esse sistema dispõe de uma fonte de radiação policromática UV/Visível, assegurada por 3 lampadas 1,7 UVMatts potência. Essa lâmpada segundo especificações do fabricante (SANKYO-DENDKI) apresenta máximos de emissão entre 253,1 nm e $320,0 \mathrm{~nm}$, suas dimensões são de $210,5 \mathrm{~mm}$ de comprimento e $15,5 \mathrm{~mm}$ de diâmetro, com potência para a emissão de 1,7 Watts/UV, e um tempo médio de vida de aproximadamente 6000 horas. 
O reator consiste em uma caixa de madeira com uma porta para abertura frontal, projetada para a manipulação dos experimentos, acoplada ao fundo deste reator foi colocado um agitador magnético para que haja agitação continua durante o ensaio, conforme Figura 13. As paredes do reator foram revestidas com papel alumínio para assegurar que toda a radiação fosse refletida sobre a amostra. As três lâmpadas UV foram instaladas na parte superior do reator (Figura 13). Foram feitos dois orifícios, um na lateral onde foi colocada uma mangueira com uma seringa, para a coleta das amostras do efluente degradado, nos intervalos de tempos determinados e outro na parede superior, onde foi instalado um termômetro de mercúrio para o controle da temperatura. Na parede de trás do reator foi instalado um cooler para diminuir a temperatura no interior da caixa.

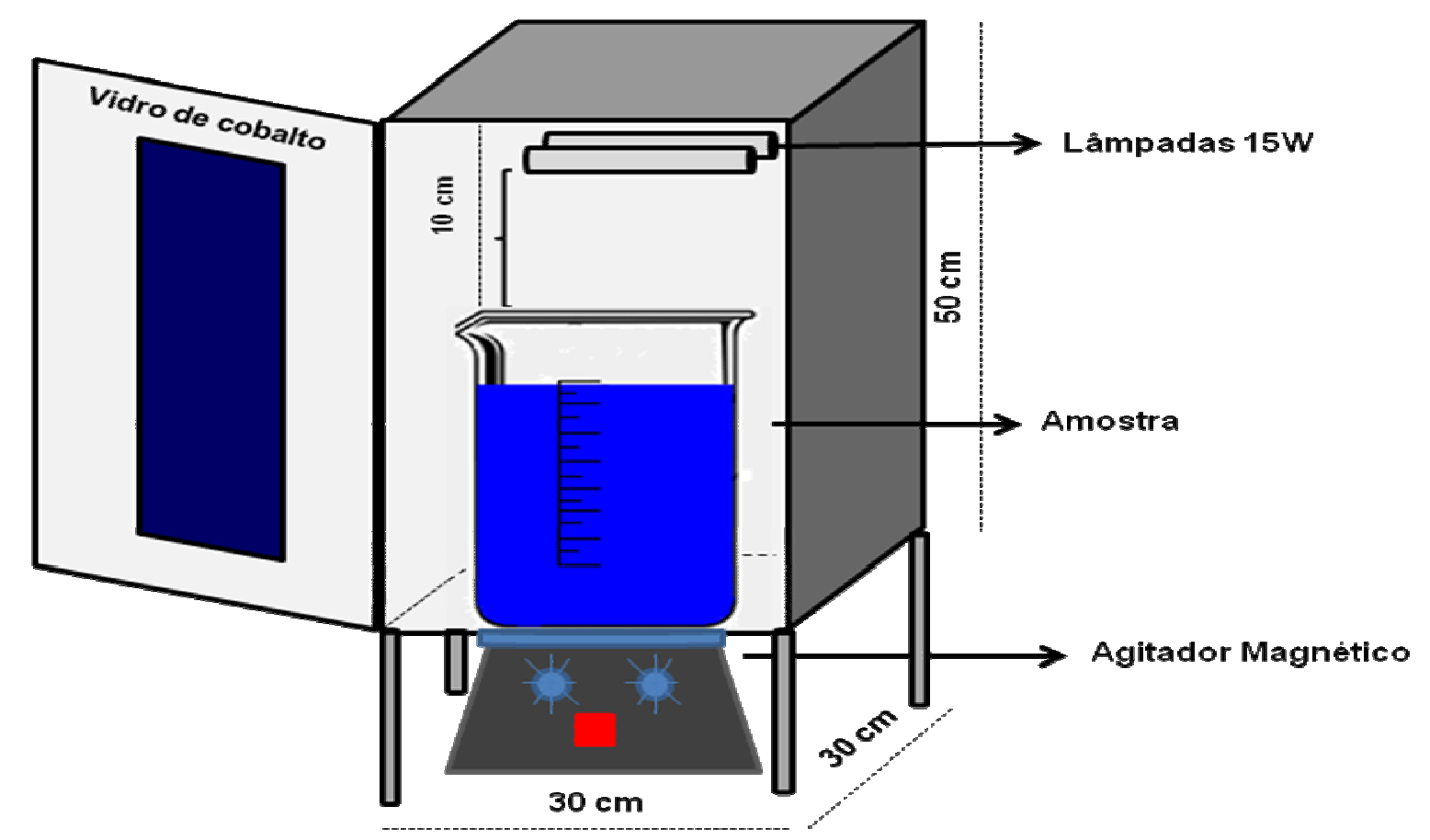

Figura 13 - Interior do reator, placa de agitação magnética, lâmpadas de radiação UV, mangueira e seringa para captação de amostras.

O reator permaneceu fechado durante o seu funcionamento, por questão de segurança e também para que toda a radiação UV fosse incidida apenas sob a amostra. O controle visual foi feito por meio de uma abertura fechada por vidro de 
cobalto que foi instalado na porta dianteira do reator, o qual não permite que a radiação UV ultrapasse.

\subsection{Metodologia}

A metodologia proposta para este estudo apresenta o desenvolvimento experimental o qual envolveu uma série de tingimentos com corantes reativos bifuncionais baseados no catálogo da empresa Clariant, o qual específica as receitas, que devem ser seguidas nos processos de tingimentos.

Os respectivos efluentes gerados por estes tingimentos foram tratados por um processo oxidativo avançado com $\mathrm{H}_{2} \mathrm{O}_{2}$ e radiação UV com a finalidade de avaliar a eficiência da remoção de cor dos efluentes. Após o tratamento, esta água foi reutilizada para os novos tingimentos e as amostras tingidas foram utilizadas para avaliar a eficiência da reprodução de cor. Para facilitar o entendimento do procedimento experimental, o trabalho foi dividido em três etapas distintas:

- Processo de tingimento;

- Tratamento do efluente e análise dos mesmos;

- Tingimento com efluente tratado e análise de reprodução a cor.

A primeira e a terceira parte dos procedimentos experimentais, ou seja, todos os tingimentos foram desenvolvidos na Escola SENAI Francisco Matarazzo e a segunda foi desenvolvida na EACH-USP no Laboratório de Pesquisa de Têxteis Técnicos - LPTT, onde foram feitos os tratamentos no reator e as análises dos efluentes tratados.

\subsubsection{Processos de tingimentos}

Foram desenvolvidos uma serie de tingimentos de cores médias baseados em uma tricromia indicada pela fabricante utilizando os corantes reativos bifuncionais amarelo Drimaren CL-2R; vermelho Drimaren CL-5B e azul Drimaren HF-RL. 
Os processos de tingimentos foram realizados utilizando tecido plano $100 \%$ algodão, alvejado, com gramatura de $180 \mathrm{~g} / \mathrm{m}^{2}$. A relação de banho utilizada foi de 1:10 com massa do substrato de $5 \mathrm{~g}$ e um volume de banho total de $50 \mathrm{~mL}$ por caneca, para cada cor foram feitas dezoito canecas iguais.

Os ensaios foram realizados em um aparelho HT (High temperature) que possui até 18 canecas de aço inox 316L com bico dosador e tampa de vedação com capacidade para suportar até 8 bar de pressão, diâmetro interno de $33 \mathrm{~mm}$ e altura de $145 \mathrm{~mm}$, permitindo trabalhar com capacidade de até $100 \mathrm{ml}$ por caneca. As receitas de tingimentos foram indicadas pela empresa fabricante do corante reativo bifuncional conforme catalogo técnico e estão descritos na Tabela 10.

Tabela 10 - Receitas de tingimentos com corantes reativos bifuncional (CLARIANT, 2005).

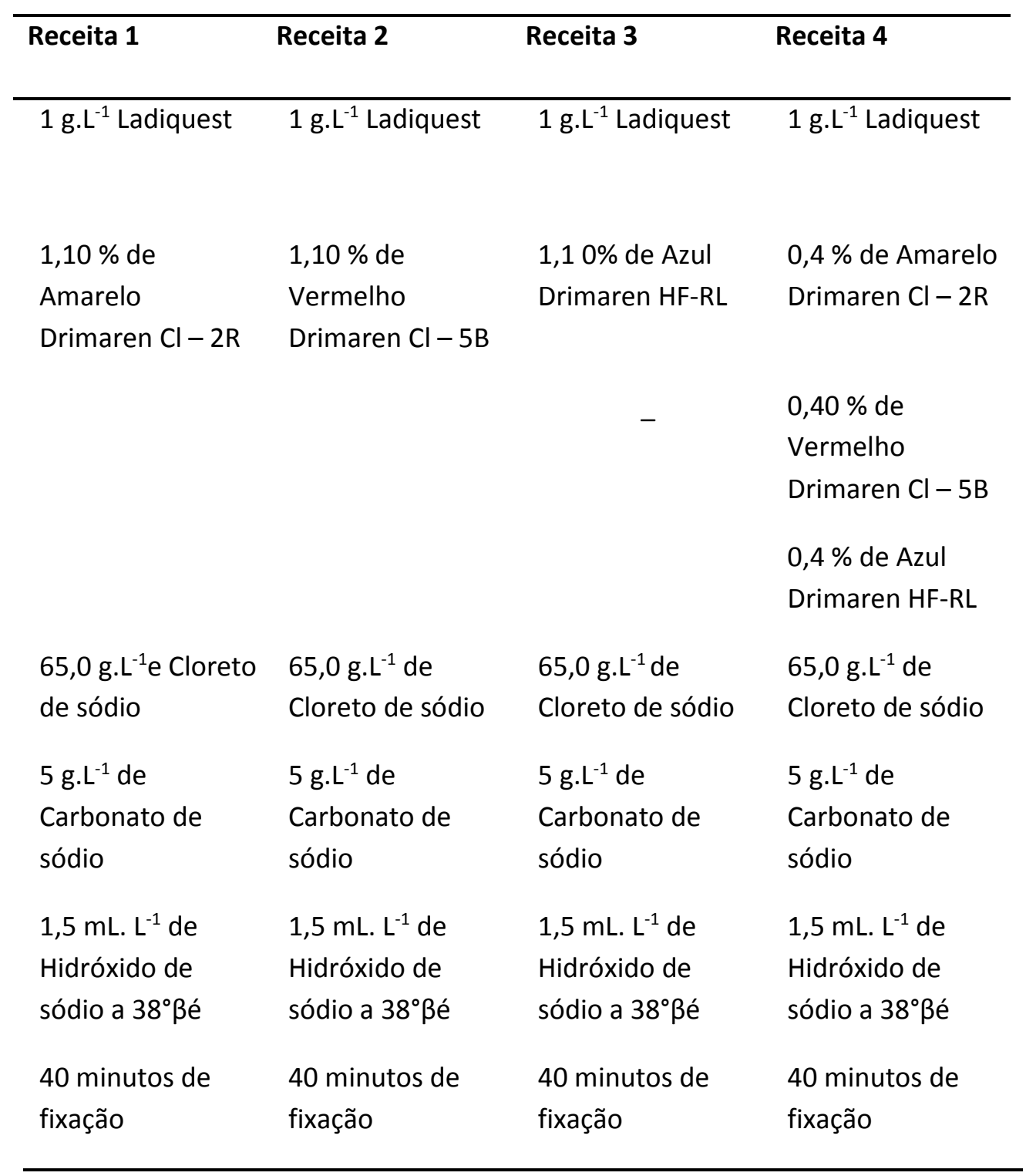


Os reagentes foram pesados conforme descrito nas Tabelas 11 e 12, no caso do sequestrante, corante e carbonato de sódio, as quantidades que deveriam ser pesadas eram valores muito baixos e se fosse feita a medição de massa poderia favorecer um erro, em função disto foram feitas soluções com concentrações conhecidas que também estão informados nas respectivas Tabelas.

Tabela 11 - Cálculo da receita de tingimento para as monocromias.

\begin{tabular}{|c|c|c|c|c|}
\hline $\begin{array}{l}\text { Sequência } \\
\text { de adição }\end{array}$ & Reagentes & $\begin{array}{l}\text { Quantidades } \\
\text { requeridas }\end{array}$ & $\begin{array}{l}\text { Soluções } \\
\text { utilizadas }\end{array}$ & Pipetagens \\
\hline A) & $\begin{array}{l}1 \mathrm{~g} \cdot \mathrm{L}^{-1} \\
\text { Ladiquest }\end{array}$ & $0,05 \mathrm{~g}$ & $1: 10$ & $0,5 \mathrm{~mL}$ \\
\hline A) & $\begin{array}{l}1,10 \% \\
\text { Corantes }\end{array}$ & $0,050 \mathrm{~g}$ & $1: 100$ & $5,5 \mathrm{~mL}$ \\
\hline A) & $\begin{array}{l}65,0 \mathrm{~g} \cdot \mathrm{L}^{-1} \mathrm{e} \\
\text { Cloreto de } \\
\text { sódio }\end{array}$ & $3,25 \mathrm{~g}$ & $\begin{array}{c}\text { Não se utilizou } \\
\text { solução }\end{array}$ & -- \\
\hline B) & $\begin{array}{l}5 \mathrm{~g} \cdot \mathrm{L}^{-1} \text { de } \\
\text { Carbonato de } \\
\text { sódio }\end{array}$ & $0,25 \mathrm{~g}$ & $1: 5$ & $1,25 \mathrm{~mL}$ \\
\hline B) & $\begin{array}{l}1,5 \mathrm{~mL} . \mathrm{L}^{-1} \mathrm{de} \\
\text { Hidróxido de } \\
\text { sódio a } 38^{\circ} \beta e ́\end{array}$ & $0,08 \mathrm{~mL}$ & $\begin{array}{c}\text { Não se utilizou } \\
\text { solução }\end{array}$ & -- \\
\hline
\end{tabular}

O processo de tingimento foi iniciado a temperatura ambiente com a adição de $42,75 \mathrm{~mL}$ ou $42,25 \mathrm{~mL}$ de água proveniente da rede de abastecimento e os seguintes reagentes: sequestrante, corante e o cloreto de sódio, conforme está determinado nas colunas de pipetagens da Tabelas 11 e 12 e representado na Figura 14 do gráfico da curva de montagem dos corantes. A temperatura foi elevada a $60^{\circ} \mathrm{C}$, subindo $1^{\circ} \mathrm{C}$ por minuto, nesta temperatura foi aguardado 20 minutos para começar a dosagem dos álcalis (carbonato de sódio e hidróxido de sódio) que foi executado em três etapas durante trinta minutos. Em seguida o processo de fixação ocorreu em quarenta minutos, mantendo a mesma temperatura, conforme determina a Figura 14. 
Tabela 12 - Cálculo da receita de tingimento para a tricromia.

\begin{tabular}{|c|c|c|c|c|}
\hline $\begin{array}{l}\text { Sequência } \\
\text { de adição }\end{array}$ & Reagentes & $\begin{array}{l}\text { Quantidades } \\
\text { requeridas }\end{array}$ & $\begin{array}{l}\text { Soluções } \\
\text { utilizadas }\end{array}$ & Pipetagens \\
\hline A) & $\begin{array}{l}1 \mathrm{~g} \cdot \mathrm{L}^{-1} \\
\text { Ladiquest }\end{array}$ & $0,05 \mathrm{~g}$ & $1: 10$ & $0,5 \mathrm{~mL}$ \\
\hline \multirow[t]{3}{*}{ A) } & $\begin{array}{l}0,40 \% \\
\text { Corante } \\
\text { Amarelo } \\
\text { Drimaren CL- } \\
2 \mathrm{R}\end{array}$ & $0,02 \mathrm{~g}$ & $1: 100$ & $2,0 \mathrm{~mL}$ \\
\hline & $\begin{array}{l}0,40 \% \\
\text { Corante } \\
\text { Vermelho } \\
\text { Drimaren CL- } \\
5 B\end{array}$ & $0,02 \mathrm{~g}$ & $1: 100$ & $2,0 \mathrm{~mL}$ \\
\hline & $\begin{array}{l}0,40 \% \\
\text { Corante Azul } \\
\text { Drimaren HF- } \\
\text { RL }\end{array}$ & $0,02 \mathrm{~g}$ & $1: 100$ & $2,0 \mathrm{~mL}$ \\
\hline A) & $\begin{array}{l}65,0 \mathrm{~g} \cdot \mathrm{L}^{-1} \mathrm{e} \\
\text { Cloreto de } \\
\text { sódio }\end{array}$ & $3,25 \mathrm{~g}$ & $\begin{array}{l}\text { Não se utilizou } \\
\text { solução }\end{array}$ & -- \\
\hline B) & $\begin{array}{l}5 \mathrm{~g} \cdot \mathrm{L}^{-1} \text { de } \\
\text { Carbonato de } \\
\text { sódio }\end{array}$ & $0,25 \mathrm{~g}$ & $1: 5$ & $1,25 \mathrm{~mL}$ \\
\hline B) & $\begin{array}{l}1,5 \mathrm{~mL} . \mathrm{L}^{-1} \text { de } \\
\text { Hidróxido de } \\
\text { sódio a } 38^{\circ} \beta e ́\end{array}$ & $0,08 \mathrm{~mL}$ & $\begin{array}{l}\text { Não se utilizou } \\
\text { solução }\end{array}$ & -- \\
\hline
\end{tabular}

No final do processo de tingimento, os efluentes foram coletados juntamente com as respectivas águas de lavagem do processo, simulando as condições industriais. 


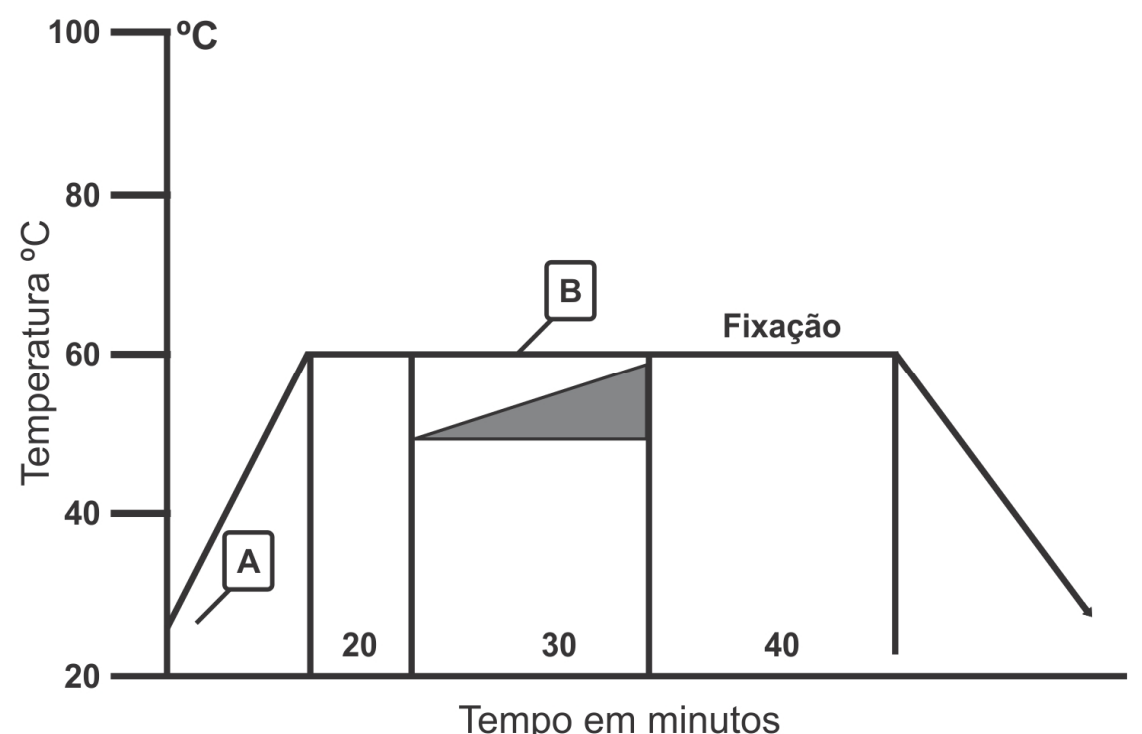

Figura 14 - Gráfico da curva de montagem dos corantes, sendo que as letras A e B indicam os reagentes que foram adicionados conforme as Tabela 11 e Tabela 12 (CLARIANT, 2005 adaptado pela autora).

Após o tingimento, estes tecidos foram submetidos ao processo de lavagem, onde se utilizou uma relação de banho de 1:20, ou seja, um volume de banho de $100 \mathrm{~mL}$ por caneca, no mesmo equipamento utilizado para o tingimento. Foi feito uma lavagem a frio com ácido acético (A) por cinco minutos para neutralização dos álcalis requeridos durante o processo de tingimento, seguindo de duas lavagens à fervura de quinze minutos cada com um detergente dispersante $(B)$ para remoção de todo o corante hidrolisado e por último uma lavagem a temperatura ambiente para remover qualquer resíduo de produto por mais cinco minutos, conforme descrito na Tabela 13 e representados na Figura 15. 
Tabela 13 - Receita de lavagem para corantes reativos heterofucionais e os respectivos cálculos (CLARIANT, 2005).

\begin{tabular}{|c|c|c|c|c|}
\hline $\begin{array}{l}\text { Sequência } \\
\text { de adição }\end{array}$ & Receita & $\begin{array}{l}\text { Quantidades } \\
\text { requeridas }\end{array}$ & $\begin{array}{l}\text { Soluções } \\
\text { utilizadas }\end{array}$ & Pipetagens \\
\hline A) & $\begin{array}{l}2 \mathrm{~mL} . \mathrm{L}^{-1} \text { ácido } \\
\text { acético }\end{array}$ & $0,2 \mathrm{~mL}$ & $\begin{array}{c}\text { Não se utilizou } \\
\text { solução }\end{array}$ & -- \\
\hline B) & $\begin{array}{l}1 \mathrm{~g} \cdot \mathrm{L}^{-1} \text { detergente } \\
\text { para lavagem de } \\
\text { corante reativo }\end{array}$ & $0,1 \mathrm{~g}$ & $1: 10$ & $1,0 \mathrm{~mL}$ \\
\hline
\end{tabular}

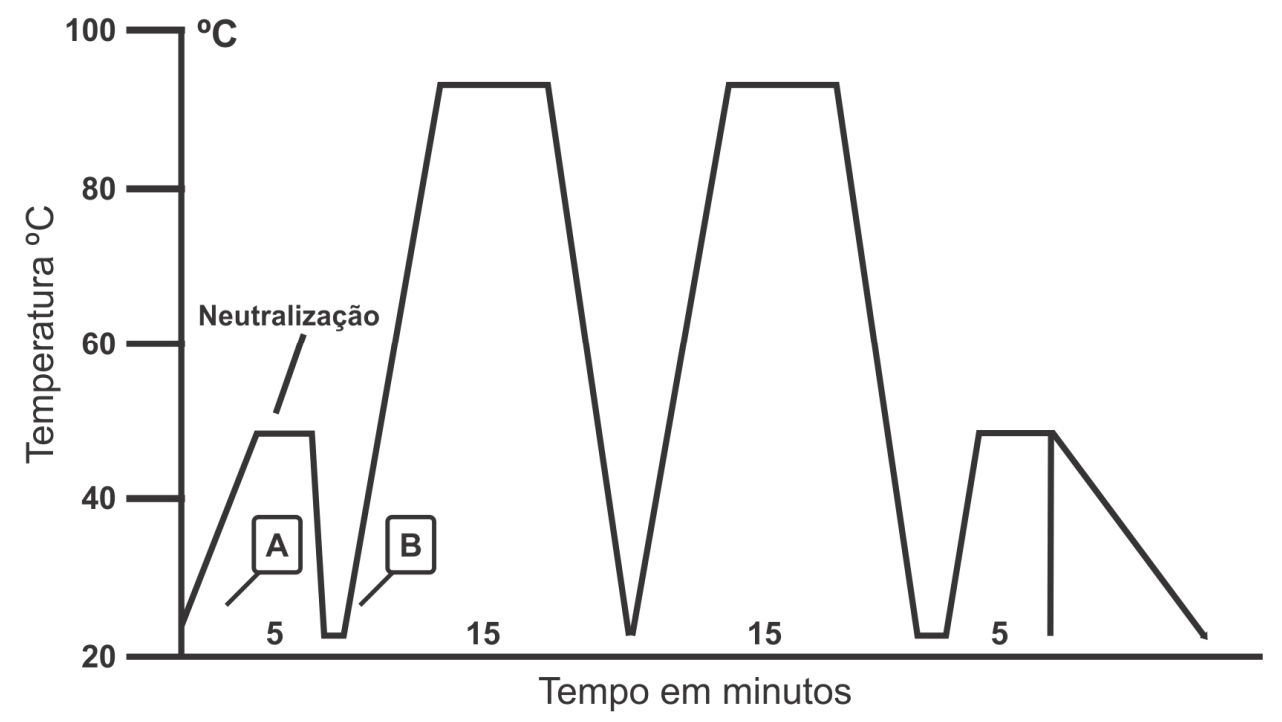

Figura 15 - Gráfico de lavagem, sendo que as letras $A$ e $B$ indicam os reagentes que foram adicionados conforme a (CLARIANT, 2005 adaptado pela autora).

4.2.2 Tratamento dos efluentes gerados por meio de processo fotoquímico com $\mathrm{H}_{2} \mathrm{O}_{2} / \mathrm{UV}$ e

Os efluentes coletados no processo de tingimento descrito no item 4.2.1 foram separados por cores. Foram retiradas três alíquotas de $500 \mathrm{~mL}$ para cada cor. 
A seguir foi feita a adição de 14,71 mmol.L-1 de peróxido de hidrogênio a 200 Volumes. Após a adição do peróxido de hidrogênio foi realizado a correção dos pHs para 4,0, 7,0 e 11,0, utilizando soluções de ácido acético e hidróxido de sódio nas concentrações de 4,0 mol.L-1, conforme a necessidade. As amostras foram colocadas em no reator fotoquímico e submetidas à ação da luz ultravioleta durante até 330 minutos. Durante o processo de degradação foram coletadas amostras de $10 \mathrm{~mL}$ aproximadamente em intervalos de $00,20,40,60,90,120,150,180,210$, 240, 270, 300 e 330 minutos de irradiação.

As amostras foram analisadas através de medição do $\mathrm{pH}$, condutividade $\mathrm{e}$ espectrofotometria. Para as medições feitas por espectrofotometria foi utilizado as leituras de absorbância lidas na faixa visível, ou seja, de 400 a 800 nm, nos quais estes valores são relacionados com a concentração de corantes. Foram feitas diversas leituras em comprimentos de ondas diferentes com a finalidade de conhecer qual o comprimento de onda de maior absorção para cada cor tingida (HASSEMER, 2006). As leituras de absorbâncias foram obtidas por um espectrofotômetro UV visível Beckman Du 640. A eficiência de remoção (que foi tratada durante todo este estudo, em \%) foi calculada pela equação 1 :

$$
\text { (A inicial) }-(\text { A final) } /(\text { A inicial })] \times 100
$$

(Equação 1)

Sendo: $A$ = absorbância

Este procedimento foi executado em triplicata com o objetivo de garantir a confiabilidade dos dados experimentais obtidos

4.2.3 Tingimento com efluente tratado e análise de reprodução da cor.

O processo de tingimento foi feito conforme o procedimento descrito no item 4.2.1 deste trabalho, apenas foi substituído os $42,67 \mathrm{~mL}$ de água potável por água de reuso. As quantidades de reagentes foram às mesmas, com exceção do cloreto de sódio que em função da condutividade existente na água de reuso foi feito o ajuste das concentrações em função das curvas de calibração mostrada nas Figuras 16 e 17. Estas curvas foram feitas preparando as soluções de cloreto de sódio, na 
concentração de $70 \mathrm{~g} \cdot \mathrm{L}^{-1}$ decrescendo em múltiplos 10 até $10 \mathrm{~g} \cdot \mathrm{L}^{-1}$ e outra partindo de 1,2 g.:-1 decrescendo em múltiplos de 0,2 até $0 \mathrm{~g} \cdot \mathrm{L}^{-1}$. As condutividades das soluções foram lidas. Com o auxílio do Excel foram feitas as curvas padrão concentração versus condutividade, sendo obtido a equação da reta e o valor de $r^{2}$ (Figuras 16 e 17).

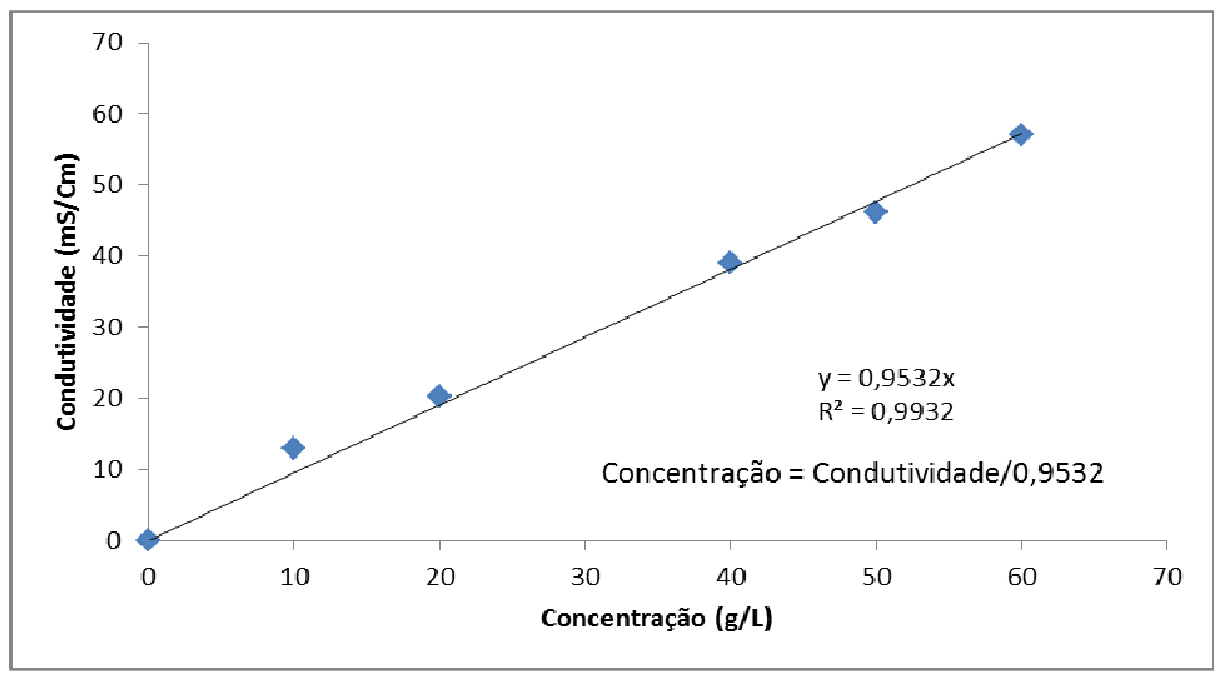

Figura 16 - Curva de calibração para concentrações acima de $10 \mathrm{~g} \cdot \mathrm{L}^{-1}$ de cloreto de sódio.

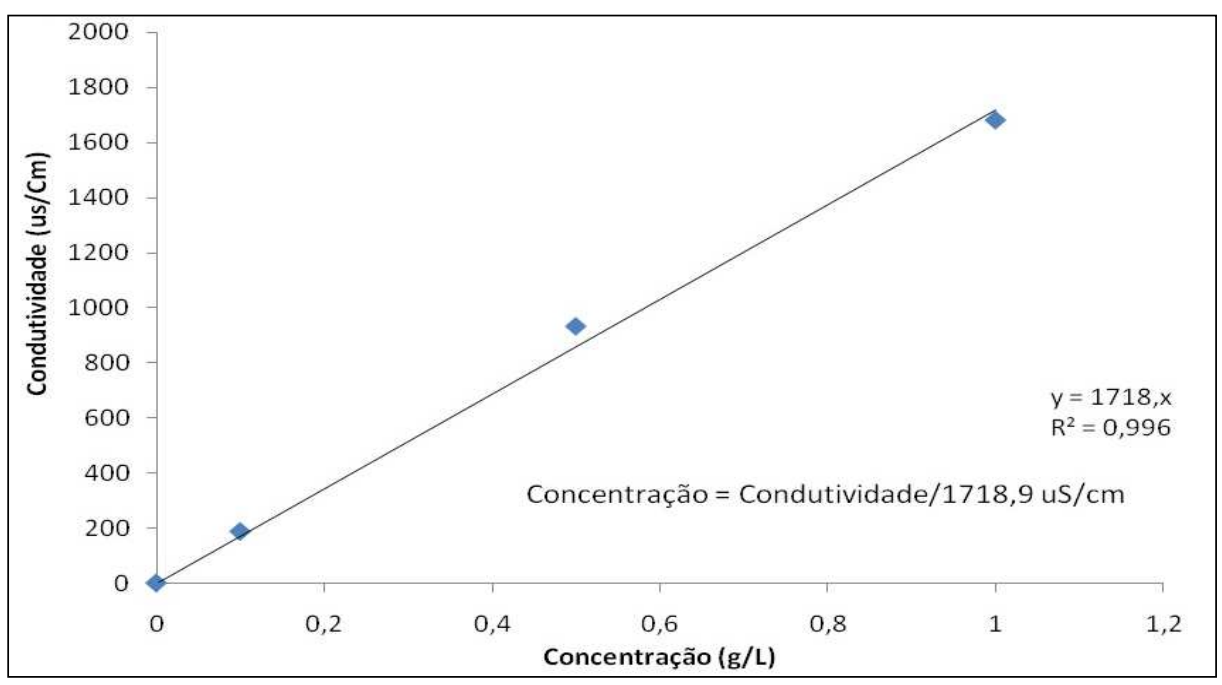

Figura 17 - Curva de calibração para concentrações inferiores a 1,2 g.L-1 de cloreto de sódio. 
Após os processos de tingimento, as amostras tingidas foram secas em uma estufa com circulação de ar à $60^{\circ} \mathrm{C}$ por 10 minutos, foram resfriadas à temperatura ambiente e posteriormente comparadas por meio das leituras de absorbância em um espectrofotômetro de bancada.

\subsubsection{Ensaios de solidez à lavagem e a luz}

Após o processo de tingimento, tanto as amostras padrões quanto as amostras provenientes do último tingimento com a água de reuso foram submetidas a ensaios de solidez à lavagem e a luz.

Segundo a ABNT NBR ISO-105-A01(2006), ABNT NBR ISO-105-A02(2006) e ABNT NBR ISO-105-A03(2006), os índices de solidez da cor são avaliados pelos seguintes parâmetros:

- Alteração de cor: corresponde às modificações ocorridas na intensidade da cor e/ou nuance após o ensaio, quando este é confrontado com a amostra padrão. O contraste entre os dois tecidos é avaliado visualmente por meio da escala cinza de alteração de cor. Esta possui 5 ou 9 pares de retângulos coloridos, os quais a nota é dada por meio dos valores que são atribuídos na Tabela 14. 
Tabela 14 - Avaliação da escala cinza de alteração de cor (Fonte: NBR ISO 105-A 03, 2006).

\begin{tabular}{cc}
\hline Grau de Solidez & Avaliação \\
\hline 5 & Cor sem alteração \\
$4-5$ & Pequena Alteração \\
4 & Pequena Alteração \\
$3-4$ & Razoável Alteração \\
3 & Razoável Alteração \\
$2-3$ & Alteração significativa \\
2 & Alteração significativa \\
$1-2$ & Grande Alteração \\
1 & Grande Alteração \\
\hline
\end{tabular}

- $\quad$ Transferência de cor: refere-se à migração do corante para o tecido testemunha, após este ser submetido aos ensaios de solidez da cor. Este contraste entre os dois tecidos-testemunha é avaliado visualmente por meio da escala cinza de transferência de cor. O procedimento de análise é bastante semelhante à escala anterior, e as notas são dadas conforme a Tabela 15. 
Tabela 15 - Avaliação da escala cinza de transferência de cor (Fonte: NBR ISO 105-A 03, 2011).

\begin{tabular}{cc}
\hline Grau de Solidez & Avaliação \\
\hline 5 & Não houve transferência \\
\hline $4-5$ & Pequena transferência \\
\hline 4 & Pequena transferência \\
\hline $3-4$ & Apreciável transferência \\
\hline 3 & Apreciável transferência \\
\hline $2-3$ & Distinta transferência \\
\hline 2 & Distinta transferência \\
\hline $1-2$ & Grande transferência \\
\hline 1 & Grande transferência \\
\hline
\end{tabular}

A) Ensaio de solidez da cor a lavagem

Foram preparados os corpos-de-prova compostos, formados pelos tecidos a serem analisados e também para cada tecido analisado, também foi cortado um tecido-testemunha, este pode ser da mesma fibra ou então um tecido multi-fibras nas dimensões 10,0 X 4,0 cm (Figura 18), costurando em duas extremidades (ABNT NBR ISO 105 - C06, 2010).

Foi preparado uma solução de lavagem com 4,0 g/L de detergente e o procedimento de lavagem executado foi o $\mathrm{A} 1 \mathrm{M}$, conforme a Tabela 16 que é o mais utilizado no mercado atualmente. 


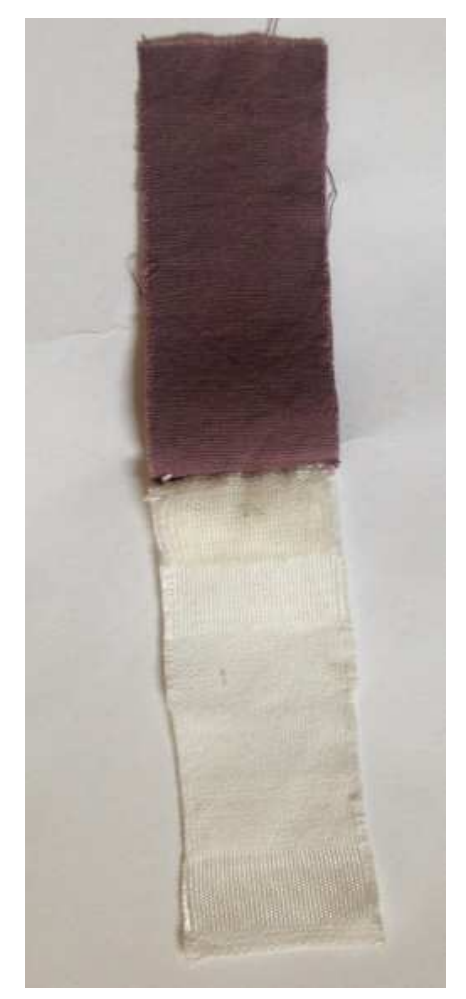

Figura 18 - Corpo de prova composto.

Ao término do processo, os corpos-de-prova composto foram enxaguados duas vezes durante 60 segundos com $100 \mathrm{ml}$ de água à $40^{\circ} \mathrm{C}$, posteriormente foi retirado o excesso de água e secos pendurados em temperatura que não excedeu $60^{\circ} \mathrm{C}$, mantendo apenas um lado da costura unida.

O tecido foi avaliado quanto à alteração de cor e o tecido-testemunha quanto à transferência de cor, ambos utilizando as suas respectivas escalas cinza. 
Tabela 16 - Condições de ensaio (Fonte: ABNT NBR ISO 105-C06, 2010).

\begin{tabular}{cccccccc}
\hline $\begin{array}{c}\text { Ensaio } \\
\mathrm{n}^{\circ}\end{array}$ & $\begin{array}{c}\text { Temperatura } \\
{ }^{\circ} \mathrm{C}\end{array}$ & $\begin{array}{c}\text { Volume } \\
\text { Solução } \\
\mathrm{ml}\end{array}$ & $\begin{array}{c}\text { Teor de } \\
\text { Cloro } \\
\text { Livre } \%\end{array}$ & $\begin{array}{c}\text { Perborato } \\
\text { de Sódio } \\
\mathrm{g} / \mathrm{L}\end{array}$ & $\begin{array}{c}\text { Tempo } \\
\mathrm{min}\end{array}$ & $\begin{array}{c}\text { Número } \\
\text { de } \\
\text { esferas } \\
\text { de aço }\end{array}$ & pH ajustado \\
\hline A1S & 40 & 150 & 0 & 0 & 30 & 10 & Sem ajuste \\
A1M & 40 & 150 & 0 & 0 & 45 & 10 & Sem ajuste \\
A2S & 40 & 150 & 0 & 1 & 30 & 10 & Sem ajuste \\
B1S & 50 & 150 & 0 & 0 & 30 & 25 & Sem ajuste \\
B1M & 50 & 150 & 0 & 0 & 45 & 50 & Sem ajuste \\
B2S & 50 & 150 & 0 & 1 & 30 & 25 & Sem ajuste \\
C1S & 60 & 50 & 0 & 0 & 30 & 25 & $10,5 \pm 0,1$ \\
C1M & 60 & 50 & 0 & 0 & 45 & 50 & $10,5 \pm 0,1$ \\
C2S & 60 & 50 & 0 & 1 & 30 & 25 & $10,5 \pm 0,1$ \\
D1S & 70 & 50 & 0 & 0 & 30 & 25 & $10,5 \pm 0,1$ \\
D1M & 70 & 50 & 0 & 0 & 45 & 100 & $10,5 \pm 0,1$ \\
D2S & 70 & 50 & 0 & 1 & 30 & 25 & $10,5 \pm 0,1$ \\
D3S & 70 & 50 & 0,015 & 0 & 30 & 25 & $10,5 \pm 0,1$ \\
D3M & 70 & 50 & 0,015 & 0 & 45 & 100 & $10,5 \pm 0,1$ \\
E1S & 95 & 50 & 0 & 0 & 30 & 25 & $10,5 \pm 0,1$ \\
E2S & 95 & 50 & 0 & 1 & 30 & 25 & $10,5 \pm 0,1$ \\
\hline
\end{tabular}

B) Ensaio de solidez da cor à luz

Para o ensaio de solidez foi utilizado o método europeu, onde foi empregado um aparelho chamado Xenotest BETA 150S, produzido pela empresa Atlas, com irradiação de intensidade xenochrome 300 de $45 \mathrm{~W} / \mathrm{m}^{2} \mathrm{~min} / 120 \mathrm{~W} / \mathrm{m}^{2} \max$. Os tecidos tintos com a tricromia estudada foram colados em uma cartolina branca nas dimensões de $100 \times 92 \mathrm{~mm}$. 
Segundo a ABNT NBR ISO-105-B02(2008), os índices de solidez da cor à luz são avaliados por meio da escala azul, onde cada nota é dada de acordo com a Tabela 17.

Tabela 17 - Avaliação da escala azul de alteração de cor (Fonte: NBR ISO 105-B02, 2008).

\begin{tabular}{cc}
\hline Grau de Solidez & Avaliação \\
\hline 1 & Muito pobre \\
2 & Pobre \\
3 & Média \\
4 & Bastante boa \\
5 & Muito boa \\
6 & Excelente \\
7 & Excepcional \\
\hline
\end{tabular}

A cartolina foi colocada no Xenotest junto com a escala de referência e submetido a 40 horas de tempo de exposição da lâmpada nas seguintes condições:

- Energia (Irradiação): $42 \mathrm{~W} / \mathrm{m}^{2}$.

- Temperatura da Câmera: $30^{\circ} \mathrm{C}$

- Umidade Relativa: $50 \%$.

\subsubsection{Análise de Carbono orgânico total}

O Carbono total orgânico é uma análise que determina quantitativamente o carbono orgânico que pode ser oxidado a $\mathrm{CO}_{2}$, por meio desta, é possível 
determinar a taxa de mineralização, ou seja é um indicador da eficiência do processo fotoquímico (HASSEMER, 2012; MANENTI, 2014).

Os teores de carbono orgânico total (COT) das amostras provenientes do processo fotoquímico foram determinados em colaboração com o Laboratório de Engenharia e Controle Ambiental da Unifesp - Diadema.

As amostras de efluentes produzidos e tratados pelo processo fotoquímico foram acidificadas com ácido nítrico $\mathrm{HNO}_{3}$ a 1 mol. $\mathrm{L}^{-1-}$. Foram retiradas alíquotas de $3,0 \mathrm{~mL}$ de cada amostra, estas foram filtradas em filtros de $0,45 \mu \mathrm{m}$ e completadas para $30 \mathrm{~mL}$ com água destilada deionizada. Após o preparo, as amostras foram submetidas à quantificação de carbono orgânico total (COT), posteriormente foi construída a curva analítica utilizando um padrão de glicose a 250 mg. L-1. 


\section{RESULTADOS E DISCUSSÃO}

\subsection{Perfil de degradação dos corantes}

Foi realizado a produção dos efluentes, por meio dos tingimentos dos tecidos utilizando os corantes amarelo Drimaren CL-2R, Vermelho Drimaren CL-5B e azul Drimaren HF-RL conforme descrito no item 4.2.1 com o objetivo de conhecer o perfil de degradação de cada corante. As Figuras 19, 20 e 21 demonstram os tingimentos desenvolvidos com os três corantes tintos isoladamente e posteriormente foram tintos tecidos com a tricromia (Figura 22), em porcentagens iguais, conforme procedimento mencionado no mesmo item. Os efluentes gerados foram caracterizados em relação ao $\mathrm{pH}$, condutividade e cor antes e após os tratamentos via processo oxidativo avançado.

$\mathrm{Na}$ Figura 22 estão demonstrados os tecidos tintos com a tricromia, em porcentagens iguais, conforme mencionado no item 4.2.1.

$$
\text { Amarelo Drimaren } \mathrm{CL}-2 \mathrm{R}
$$

Padrão

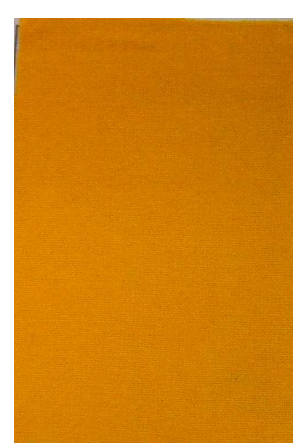

$1^{\circ}$ Reuso

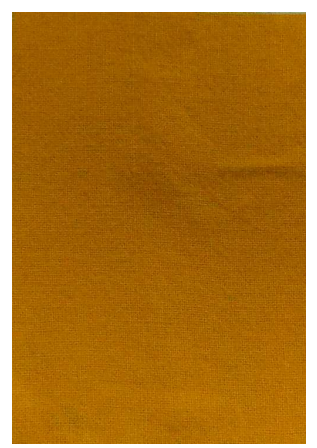

$2^{\circ}$ Reuso

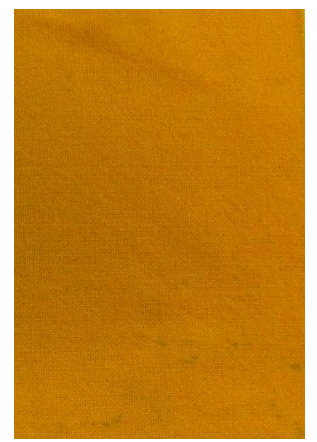

Figura 19 - Tingimentos executados com corante amarelo drimaren CL-2R. 
Vermelho Drimaren $\mathrm{CL}-5 \mathrm{~B}$

Padrão

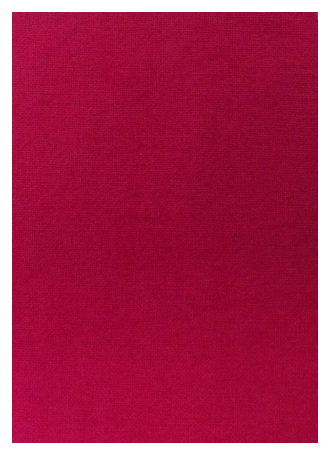

1ํㅡㄹ Reuso

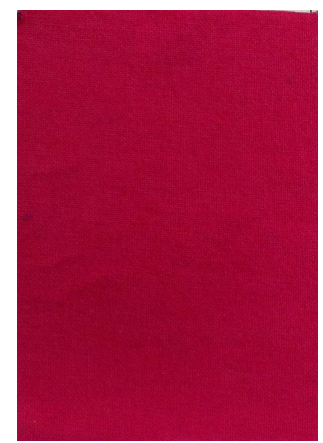

2ำ Reuso

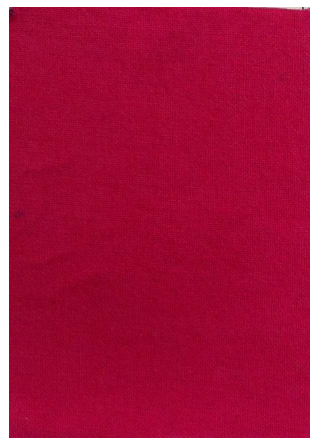

Figura 20 - Tingimentos executados com corante vermelho drimaren CL-5B.

A

Azul Drimaren HF-RL

Padrão

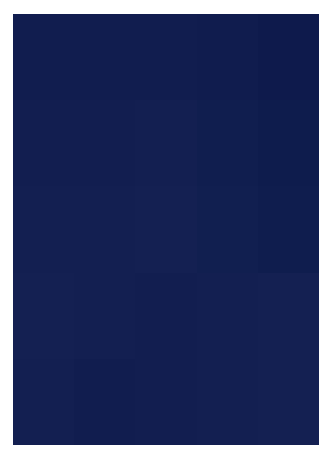

1ำ Reuso

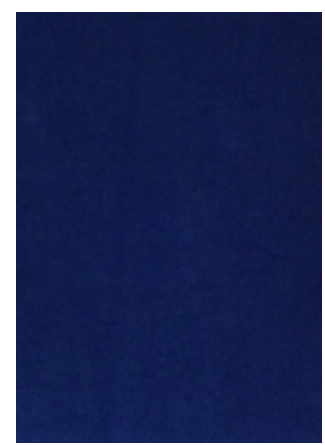

$2^{\circ}$ Reuso

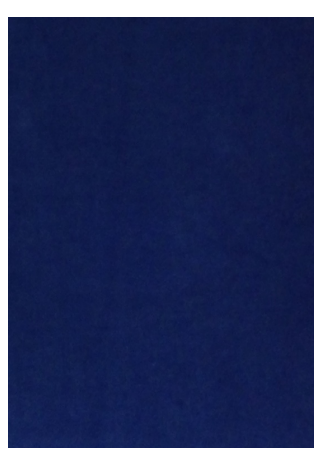

Figura 21 - Tingimentos executados com corante azul drimaren HF-RL. 
Padrão

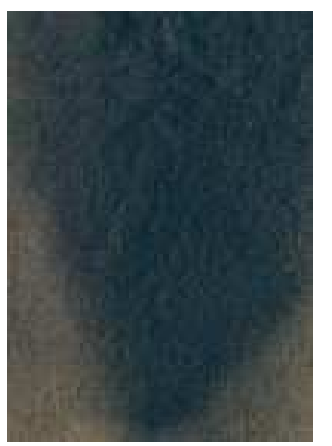

$1 \stackrel{\circ}{\text { Reuso }}$

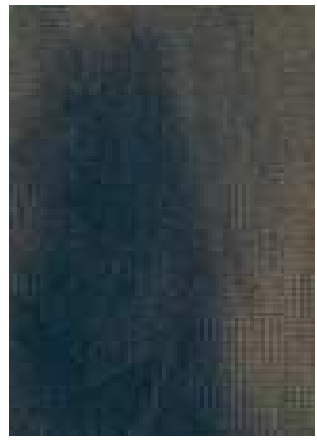

$2^{\circ}$ Reuso

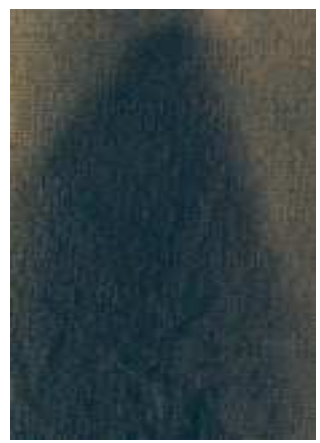

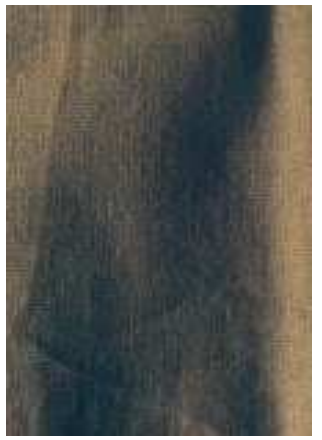

3ํㅗeuso

Figura 22- Tingimentos executados com a tricromia de corantes Drimaren.

Com base nas literaturas consultadas, o trabalho experimental confirmou uma redução significativa nos valores de absorbância, quando comparados às características dos efluentes brutos à dos efluentes tratados, isto pode ser analisado por meio das Tabelas 18 e 19 (HASSEMER, 2006; CLAUSEN e TAKASHIMA, 2007; ELMORSI et al., 2010; KALSOOM et al., 2012). Estas Tabelas referem-se às características iniciais dos efluentes obtidos a partir do tingimento com os corantes amarelo Drimaren CL-2R, vermelho Drimaren CL-5B, azul Drimaren HF-RL e a dos três corantes tintos juntos em estado bruto, sem a correção de pH que foi feita posteriormente para o tratamento fotoquímico, também foi possível observar que o tratamento com $\mathrm{H}_{2} \mathrm{O}_{2} / \mathrm{UV}$ provoca uma redução no $\mathrm{pH}$ que no início do tratamento era 4,0 . 
Tabela 18 - Parâmetros iniciais e finais após tratamento fotoquímico em pH 4,0 do efluente produzido com corante amarelo Drimaren CL-2R, Vermelho Drimaren CL-5B e Azul Drimaren HF-RL.

\begin{tabular}{|c|c|c|c|c|c|c|c|}
\hline \multicolumn{8}{|c|}{ Parâmetros Físicos Químicos } \\
\hline & & \multicolumn{2}{|c|}{$\begin{array}{c}\text { Amarelo } \\
\text { Drimaren CL-2R }\end{array}$} & \multicolumn{2}{|c|}{$\begin{array}{c}\text { Vermelho } \\
\text { Drimaren CL-5B }\end{array}$} & \multicolumn{2}{|c|}{$\begin{array}{c}\text { Azul Drimaren } \\
\text { HF-RL }\end{array}$} \\
\hline & & $\begin{array}{l}\text { Efluente } \\
\text { Inicial }\end{array}$ & $\begin{array}{c}\text { Efluente } \\
\text { Final }\end{array}$ & $\begin{array}{l}\text { Efluente } \\
\text { Inicial }\end{array}$ & $\begin{array}{c}\text { Efluente } \\
\text { Final }\end{array}$ & $\begin{array}{l}\text { Efluente } \\
\text { Inicial }\end{array}$ & $\begin{array}{c}\text { Efluente } \\
\text { Final }\end{array}$ \\
\hline $\begin{array}{c}\mathrm{Ph} \\
\text { Condutividade }\end{array}$ & & $\begin{array}{c}5,45 \\
1,8300\end{array}$ & $\begin{array}{c}3,60 \\
1,8300\end{array}$ & $\begin{array}{c}4,80 \\
3,3270\end{array}$ & $\begin{array}{c}3,90 \\
3,3270\end{array}$ & $\begin{array}{c}6,10 \\
4,8120\end{array}$ & $\begin{array}{c}3,90 \\
4,8550\end{array}$ \\
\hline Absorbâncias & $\begin{array}{l}250 \lambda \\
350 \lambda \\
450 \lambda \\
550 \lambda \\
650 \lambda \\
750 \lambda\end{array}$ & $\begin{array}{l}1,0791 \\
0,7168 \\
0,1006 \\
0,0937 \\
0,0820 \\
0,0560\end{array}$ & $\begin{array}{l}0,1997 \\
0,1057 \\
0,0029 \\
0,0001 \\
0,0003 \\
0,0001\end{array}$ & $\begin{array}{l}0,6199 \\
0,4146 \\
0,0733 \\
0,1407 \\
0,0120 \\
0,0036\end{array}$ & $\begin{array}{l}0,2511 \\
0,1318 \\
0,0041 \\
0,0041 \\
0,0044 \\
0,0045\end{array}$ & $\begin{array}{l}4,5000 \\
4,5000 \\
0,0934 \\
0,2268 \\
0,1331 \\
0,0072\end{array}$ & $\begin{array}{l}2,7264 \\
4,5000 \\
0,0825 \\
0,0275 \\
0,0081 \\
0,0016\end{array}$ \\
\hline
\end{tabular}

Tabela 19 - Parâmetros iniciais e finais após tratamento fotoquímico em pH 4,0 do efluente produzido com a tricromia de corantes reativos.

\begin{tabular}{c|c|c|c}
\hline \multicolumn{2}{c|}{ Parâmetros Físicos Químicos } & \multicolumn{2}{c}{ Valores } \\
\hline \multicolumn{2}{c|}{} & Efluente Bruto & Efluente Tratado \\
\hline \multicolumn{2}{c|}{ pH } & 6,40 & 3,90 \\
Condutividade & $250 \lambda$ & 2,3180 & 2,3740 \\
& $350 \lambda$ & 3,2708 & 1,0960 \\
\multirow{2}{*}{ Absorbâncias } & $450 \lambda$ & 4,5000 & 0,2841 \\
& $550 \lambda$ & 0,2617 & 0,1306 \\
& $650 \lambda$ & 0,3921 & 0,0871 \\
& $750 \lambda$ & 0,1006 & 0,0590 \\
& & 0,0273 & 0,0420 \\
\hline
\end{tabular}

Também foi observado que o tempo de exposição à luz UV irá depender da molécula do corante a ser tratado, no caso dos três corantes estudados isoladamente foi observado que o vermelho Drimaren CL-5B possui uma resistência maior ao processo de remoção da cor do que o corante amarelo Drimaren CL-2R e o azul Drimaren HF-RL, tanto que o tempo de exposição necessário para ambos foi de 150 minutos e o vermelho de 240 minutos, a literatura também faz citação a este comportamento que tende a variar conforme a estrutura química do mesmo (ROSA, 2010). Este comportamento também foi observado quando foi analisado o comportamento de remoção da cor do tingimento realizado com os três corantes 
juntos (tricromia) em porcentagens iguais, o tempo aumentou para 270 minutos, nas mesmas condições de tratamento.

As absorbâncias foram lidas nas faixas do visível (400 nm a 800 nm), na faixa do visível, os valores são relacionados diretamente com a concentração de corantes, foram executadas três leituras em comprimentos de ondas distintos com a finalidade de descobrirmos qual o comprimento de onda de maior absorção para os corantes estudados (HASSEMER, 2006).

\subsubsection{Influência do $\mathrm{pH}$}

$\mathrm{O}$ H durante a pesquisa se mostrou de suma importância na reação fotoquímica e também para os efluentes gerados com os corantes estudados. A estabilidade do peróxido de hidrogênio tende a alteração conforme variação do $\mathrm{pH}$ e da temperatura, o aumento do $\mathrm{pH}$ e/ou temperatura favorece a decomposição do mesmo (VOLOSHIN et al., 2007 ; PERES et al., 2008 ; ALVES, 2010). Em função disto, um dos objetivos determinados neste trabalho foi verificar a influência da variação do $\mathrm{pH}$ no processo fotoquímico com $\mathrm{H}_{2} \mathrm{O}_{2} / \mathrm{UV}$ na degradação dos grupos cromóforos da tricromia de corantes selecionada.

Foi avaliado a influência do comportamento de remoção de cor dos efluentes produzidos em três faixas de $\mathrm{pH}$ 4,0,7,0 e 11,0, sendo que cada processo foi executado em triplicata com o objetivo de dar confiabilidade aos resultados obtidos. A seleção dos valores de $\mathrm{pH}$ para a realização dos processos de remoção foram baseados em três características importantes; o pH 11,0 foi selecionado por ser normalmente a faixa ideal para o tingimento com os corantes reativos, no $\mathrm{pH}$ 7,0 por ser neutro e caso fosse ideal, não seria necessário correção de pH para o próximo tingimento e em $\mathrm{pH} 4,0$, pois a acidulação é responsável por interromper o mecanismo de reação da classe de corantes estudada.

Após os respectivos ajustes de $\mathrm{pH}$ foi feita a adição de $14,71 \mathrm{mmol} . \mathrm{L}^{-1}$ de peróxido de hidrogênio $50 \%$.

Os resultados do processo de degradação dos três corantes tingidos isoladamente nas faixas de $\mathrm{pH}$ 4,0, 7,0 e 11,0 são mostrados nas Tabelas 20, 21 e 
22 e nas Figuras 23, 24 e 25, demonstraram que as características do efluente gerado pelos três corantes tintos isoladamente apresentaram comportamentos muito semelhantes. No entanto, foi possível observar que para valores de $\mathrm{pH} \mathrm{4,0}$ a degradação foi mais eficiente, mostrando uma redução nos valores de absorbância de pelo menos $91,12 \pm 0,95 \%$.

Contudo é importante ressaltar que o corante vermelho Drimaren CL-5B é mais resistente ao processo de degradação, uma vez que os corantes amarelo Drimaren CL-2R e azul Drimaren HF-RL tiveram resultados satisfatórios com tempos de 150 minutos (Tabelas 20 e 22 e Figuras 22, 27 e 29), comparados com 240 minutos que foram requeridos para que a degradação do corante vermelho (Tabela 21 e Figura 28) apresentasse um rendimento do processo semelhante aos outros dois corantes estudados.

A indústria têxtil normalmente utiliza mais de um corante para produzir a maioria das cores, a prática mais usual é o uso de uma tricromia básica, que corresponde ao uso de um corante amarelo, vermelho e azul (SALEM, 2010). Para a tricromia estudada foi observado que esta apresentou um comportamento muito semelhante ao dos efluentes produzidos com os corantes individualmente, a respeito do $\mathrm{pH}$ ideal, que também demonstrou sua melhor eficiência de degradação na faixa do $\mathrm{pH} \mathrm{4,0} \mathrm{(Tabela} 23$ e Figura 26). Contudo, o mesmo exigiu um aumento do tempo de exposição para 270 minutos para que os resultados de remoção de cor fossem semelhantes aos tratamentos anteriores (Figura 30).

O melhor resultado do processo de degradação ter ocorrido em $\mathrm{pH} 4,0$ também condiz com a literatura, uma vez que segundo Cavalcante et al. (2005) e Brito e Silva (2012), justificam que em valores de $\mathrm{pH}$ ácido o efeito dos capturadores de radicais, principalmente íons tais como bicarbonatos e carbonatos são anulados.

Nos corantes reativos, uma comprovação deste fenômeno seria o desaparecimento da banda de absorção a 487 a $505 \mathrm{~nm}$, ocasionada pela quebra da ligação azo $(-\mathrm{N}=\mathrm{N}-)$, que também está sendo evidenciado pela diminuição da intensidade da cor do efluente (BRITO e SILVA, 2012; RIBEIRO et al., 2013). 
Tabela 20 - Porcentagem média de remoção da cor no efluente produzido com corante Amarelo Drimaren CL-2R nas faixas de pH 4,0, 7,0 e 11,0.

\begin{tabular}{c|c|c|c}
\hline $\mathbf{p H}$ & $\begin{array}{c}\text { Absorbância Inicial } \\
\text { média }\end{array}$ & $\begin{array}{c}\text { Absorbância } \\
\text { Final média }\end{array}$ & $\begin{array}{c}\text { \% Remoção } \\
\text { média }\end{array}$ \\
\hline $\mathbf{4 , 0}$ & $0,1006 \pm 0,0003$ & $0,0029 \pm 0,0011$ & $97,11 \pm 1,13$ \\
$\mathbf{7 , 0}$ & $0,1006 \pm 0,0003$ & $0,0559 \pm 0,0025$ & $44,44 \pm 2,47$ \\
$\mathbf{1 1 , 0}$ & $0,1006 \pm 0,0003$ & $0,0864 \pm 0,0260$ & $14,12 \pm 2,60$ \\
\hline
\end{tabular}

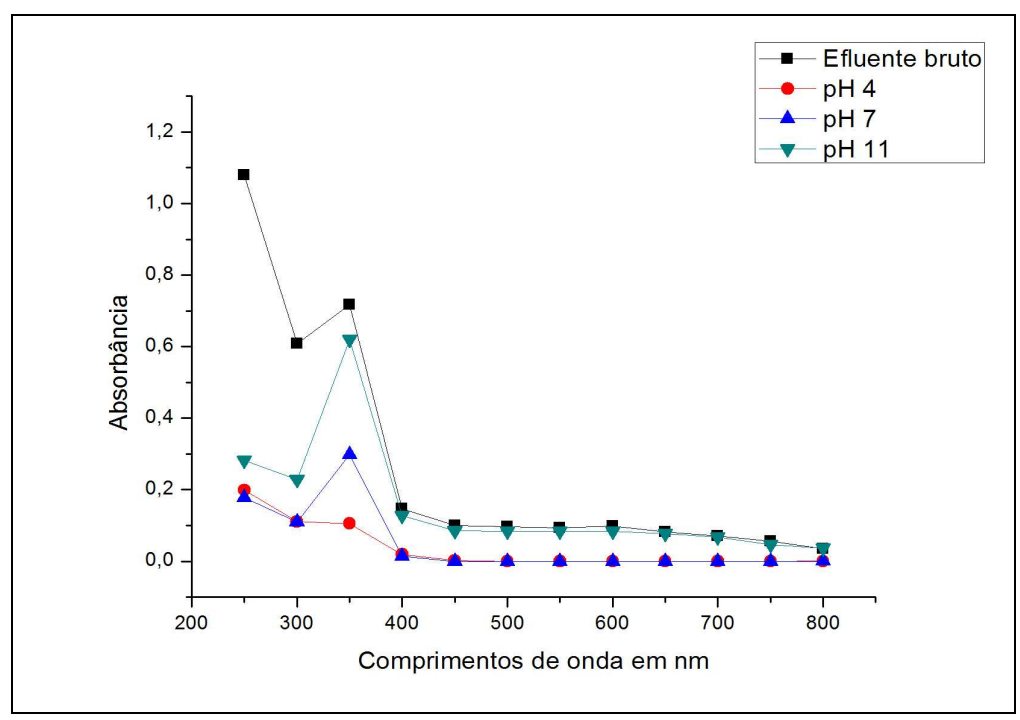

Figura 23 - Absorbâncias nas faixas UV e visível em função do comprimento de onda em nm no tempo de 150 minutos de tratamento para o efluente com corante amarelo Drimaren CL$2 \mathrm{R}$. 


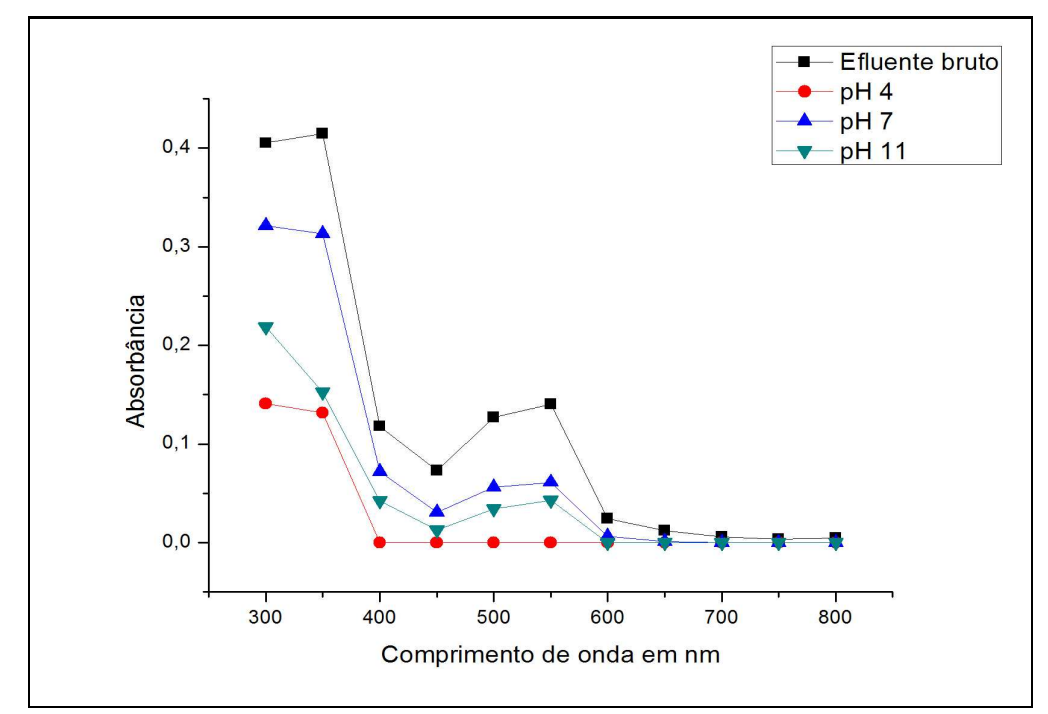

Figura 24 - Absorbâncias nas faixas UV e visível em função do comprimento de onda nm no tempo 240 minutos de tratamento para o efluente com corante vermelho Drimaren CL-5B.

Tabela 21 - Porcentagem média de remoção da cor no efluente produzido com corante Vermelho Drimaren CL-5B nas faixas de $\mathrm{pH}$ 4,0, 7,0 e 11,0.

\begin{tabular}{c|c|c|c}
\hline $\mathbf{p H}$ & Absorbância Inicial & $\begin{array}{c}\text { Absorbância } \\
\text { Final }\end{array}$ & \% Remoção \\
\hline $\mathbf{4 , 0}$ & $0,1407 \pm 0,006$ & $0,0041 \pm 0,0013$ & $97,05 \pm 0,89$ \\
$\mathbf{7 , 0}$ & $0,1407 \pm 0,006$ & $0,0612 \pm 0,0026$ & $56,50 \pm 1,84$ \\
$\mathbf{1 1 , 0}$ & $0,1407 \pm 0,006$ & $0,0431 \pm 0,0012$ & $69,36 \pm 0,87$ \\
\hline
\end{tabular}

Tabela 22 - Porcentagem média de remoção da cor no efluente produzido com corante Azul Drimaren HF- RL nas faixas de $\mathrm{pH}$ 4,0, 7,0 e 11,0.

\begin{tabular}{c|c|c|c}
\hline $\mathbf{p H}$ & Absorbância Inicial & $\begin{array}{c}\text { Absorbância } \\
\text { Final }\end{array}$ & \% Remoção \\
\hline $\mathbf{4 , 0}$ & $0,3616 \pm 0,0013$ & $0,0173 \pm 0,0017$ & $95,22 \pm 0,48$ \\
$\mathbf{7 , 0}$ & $0,3616 \pm 0,0013$ & $0,0713 \pm 0,0086$ & $80,29 \pm 2,42$ \\
$\mathbf{1 1 , 0}$ & $0,3616 \pm 0,0013$ & $0,0557 \pm 0,0090$ & $84,61 \pm 2,50$ \\
\hline
\end{tabular}




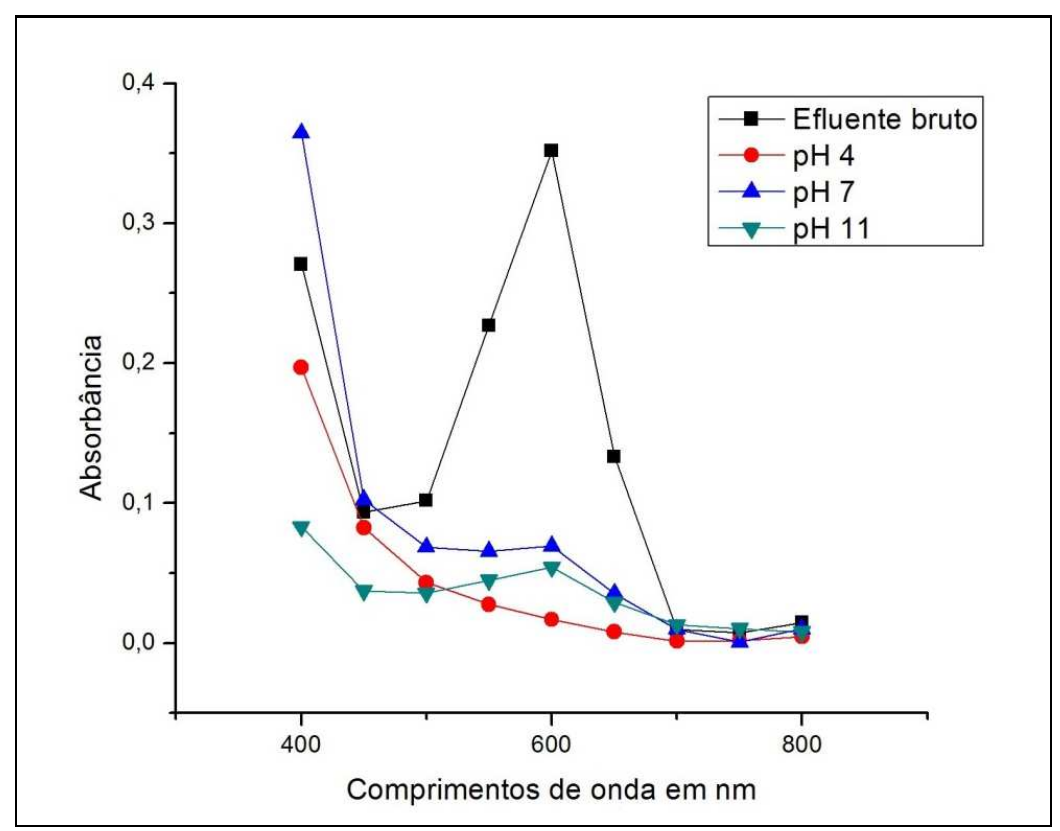

Figura 25 - Absorbâncias nas faixas UV e visível em função do comprimento de onda em nm no tempo de 150 minutos de tratamento para o efluente com corante azul Drimaren HF-RL.

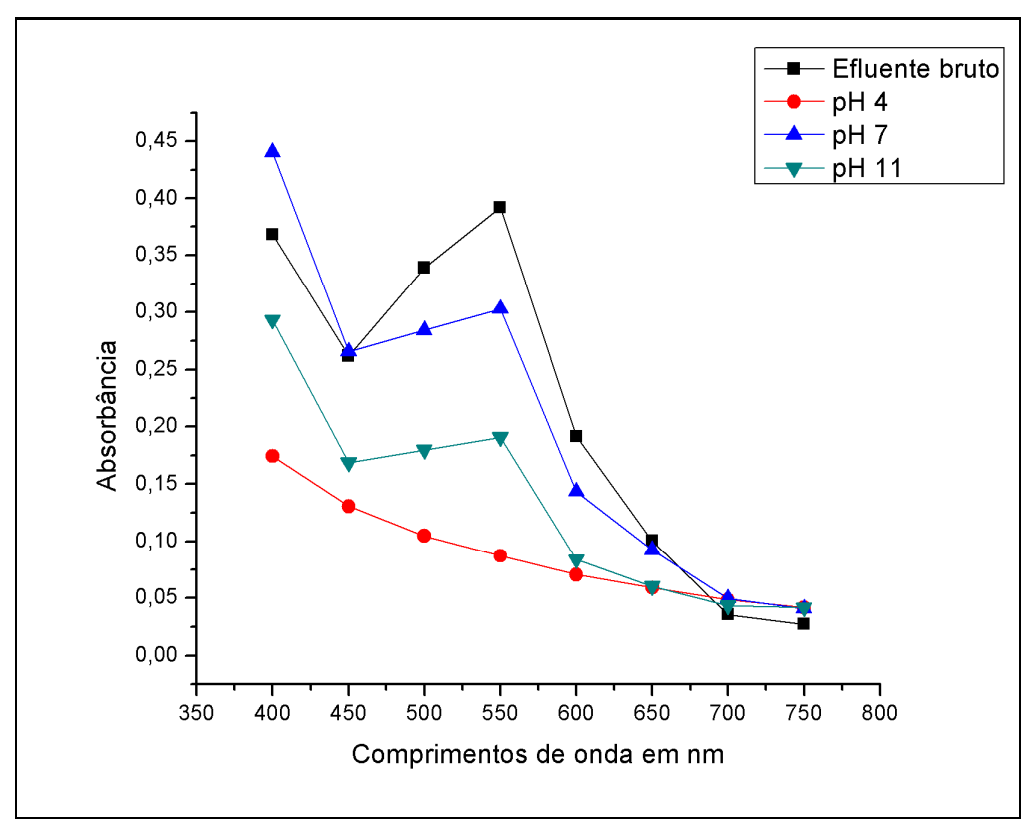

Figura 26 - Absorbâncias nas faixas UV e visível em função do comprimento de onda em nm no tempo de 270 minutos de tratamento para o efluente com a tricromia. 
Tabela 23 - Porcentagem média de remoção da cor no efluente produzido com a tricromia de corantes Drimaren nas faixas de $\mathrm{pH}$ 4,0, 7,0 e 11,0.

\begin{tabular}{c|c|c|c}
\hline $\mathbf{p H}$ & Absorbância Inicial & $\begin{array}{c}\text { Absorbância } \\
\text { Final }\end{array}$ & \% Remoção \\
\hline $\mathbf{4 , 0}$ & $0,3921 \pm 0,0004$ & $0,0348 \pm 0,0035$ & $91,12 \pm 0,95$ \\
$\mathbf{7 , 0}$ & $0,3921 \pm 0,0004$ & $0,3027 \pm 0,0121$ & $91,12 \pm 3,09$ \\
$\mathbf{1 1 , 0}$ & $0,3921 \pm 0,0004$ & $0,1908 \pm 0,0039$ & $51,33 \pm 0,99$ \\
\hline
\end{tabular}

$\mathrm{Na}$ faixa do UV, em torno dos $300 \mathrm{~nm}$ também é possível observar uma diminuição das absorbâncias que pode indicar que houve uma redução dos aromáticos no efluente (Figuras 27, 28, 29 e 30) (HASSEMER, 2006; RIBEIRO et al., 2013; Schimidt et al., 2013).

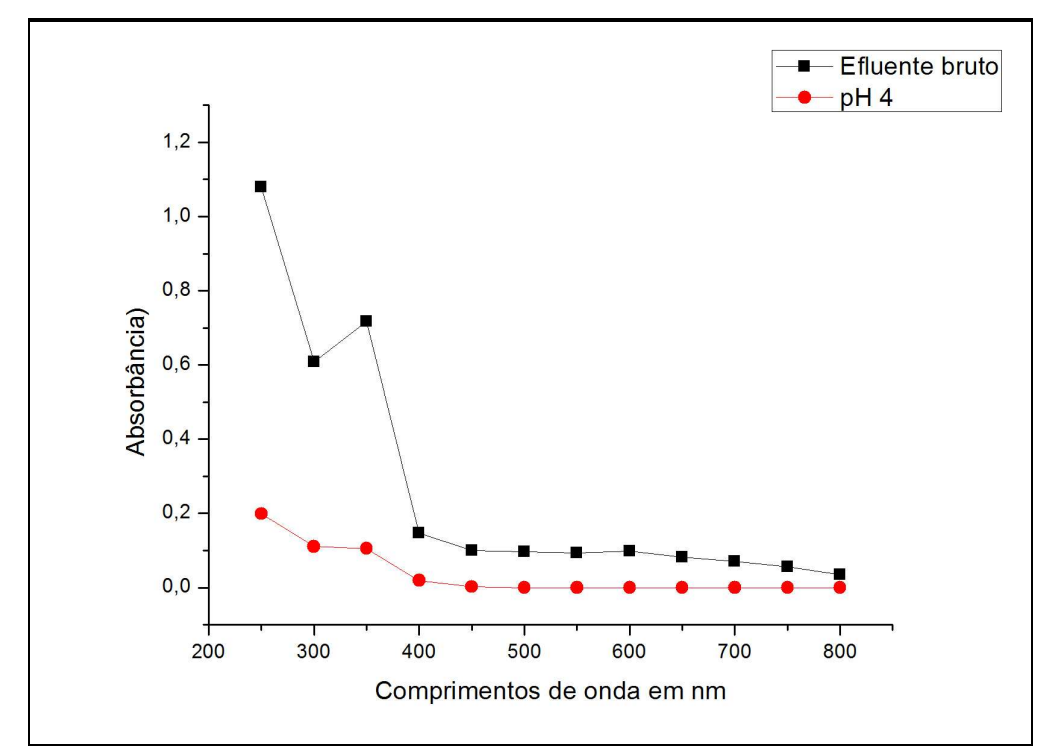

Figura 27 - Variação das absorbâncias do efluente bruto (efluente sintético produzido em laboratório com águas de lavagens) em pH 4,0, faixa de $\mathrm{pH}$ que apresentou melhor remoção de cor na faixa do visível em função do comprimento de onda nm no tempo 150 minutos para o efluente produzidos com corante amarelo Drimaren CL-2R. 


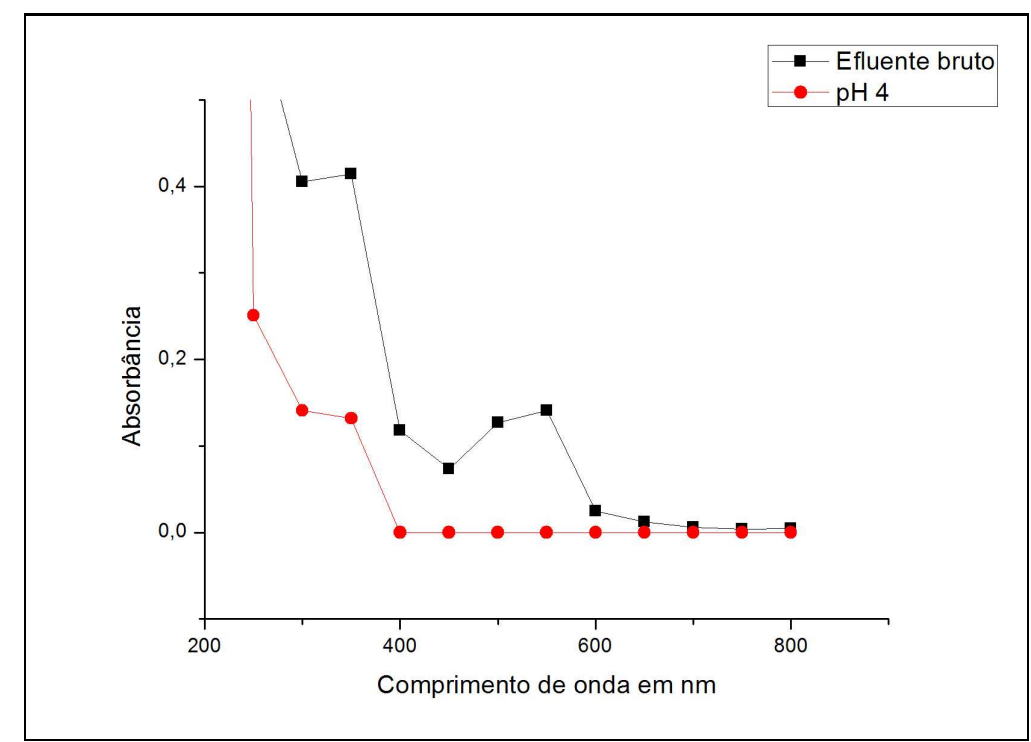

Figura 28 - Variação das absorbâncias do efluente bruto (efluente sintético produzido em laboratório com águas de lavagens) em $\mathrm{pH} 4,0$, faixa de $\mathrm{pH}$ que apresentou melhor remoção de cor na faixa do visível em função do comprimento de onda nm no tempo 240 minutos para o efluente produzidos com corante vermelho Drimaren CL-5B.

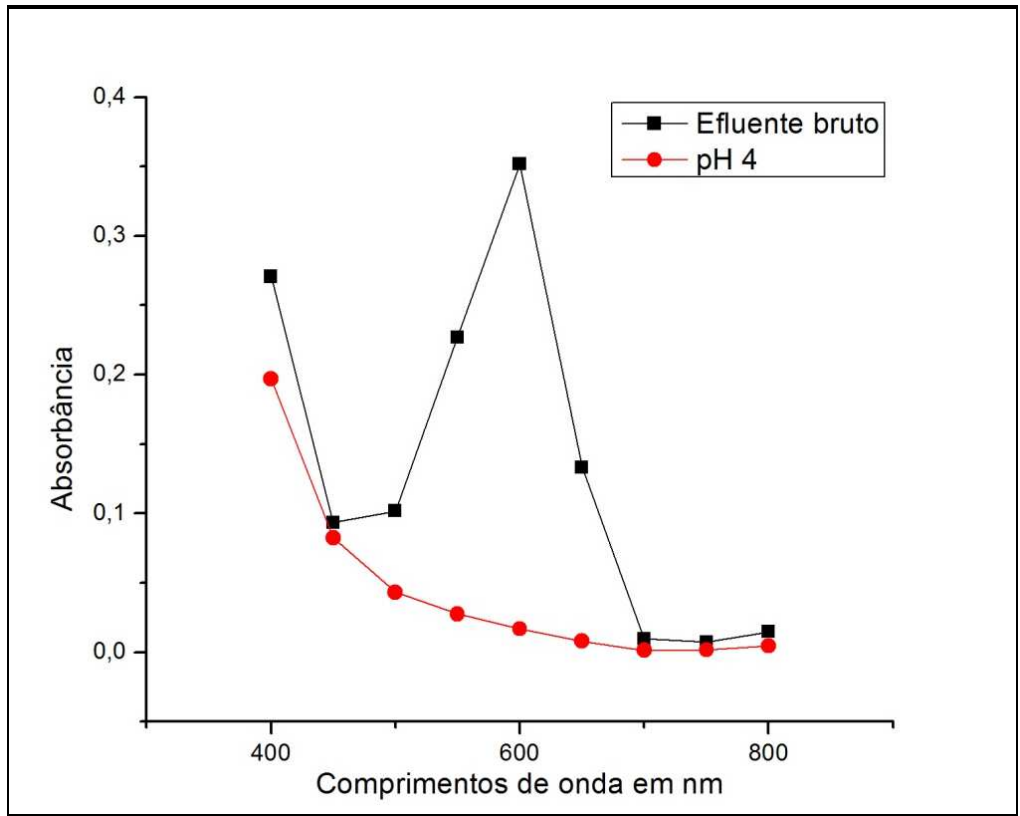

Figura 29 - Variação das absorbâncias do efluente bruto (efluente sintético produzido em laboratório com águas de lavagens) em $\mathrm{pH} 4,0$, faixa de $\mathrm{pH}$ que apresentou melhor remoção de cor na faixa do visível em função do comprimento de onda nm no tempo 150 minutos para o efluente produzidos com corante azul Drimaren HF-RL. 


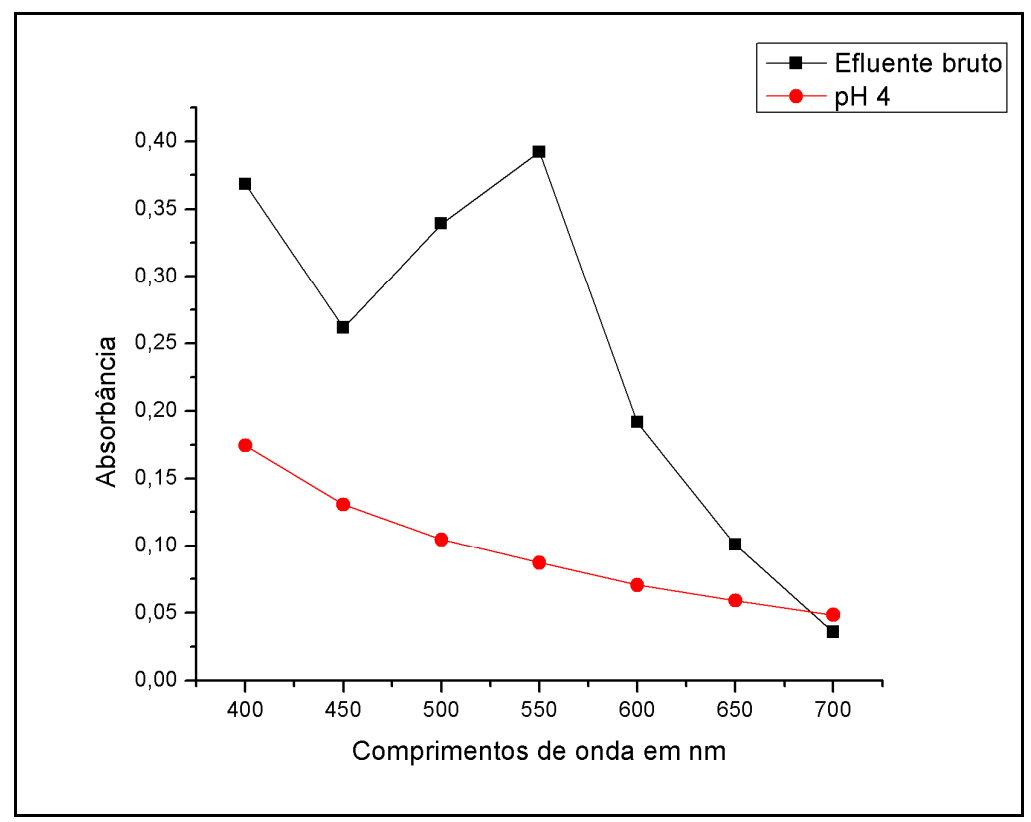

Figura 30 - Variação das absorbâncias do efluente bruto (efluente sintético produzido em laboratório com águas de lavagens) em $\mathrm{pH} 4,0$, faixa de $\mathrm{pH}$ que apresentou melhor remoção de cor na faixa do visível em função do comprimento de onda nm no tempo 270 minutos para o efluente produzidos com a tricromia.

Tabela 24 - Porcentagens de remoção de cor nos efluentes produzidos.

\begin{tabular}{ccccc}
\hline Corantes & $\begin{array}{c}\text { Amarelo } \\
\text { Drimaren CL- } \\
\text { 2R }\end{array}$ & $\begin{array}{c}\text { Vermelho } \\
\text { Drimaren CL- }\end{array}$ & $\begin{array}{c}\text { Azul } \\
\text { Drimaren HF- }\end{array}$ & Tricromia \\
& & 5B & RL & \\
\hline pH & \% Remoção & \% Remoção & \% Remoção & \% Remoção \\
\hline $\mathbf{4 , 0}$ & $97,11 \pm 1,13$ & $97,05 \pm 0,89$ & $95,22 \pm 0,48$ & $91,12 \pm 0,95$ \\
$\mathbf{7 , 0}$ & $44,44 \pm 2,47$ & $56,50 \pm 1,84$ & $80,29 \pm 2,42$ & $91,12 \pm 3,09$ \\
$\mathbf{1 1 , 0}$ & $14,12 \pm 2,60$ & $69,36 \pm 0,87$ & $84,61 \pm 2,50$ & $51,33 \pm 0,99$ \\
& & & & \\
\hline
\end{tabular}

Ainda confirmando os resultados obtidos durante o processo de degradação fotoquímica dos corantes selecionados, a Tabela 24 mostra por meio de porcentagens que o comportamento da curva cinética de remoção dos efluentes tratados por processo $\mathrm{UV} / \mathrm{H}_{2} \mathrm{O}_{2}$ foi mais eficiente na faixa de $\mathrm{pH}$ 4,0. Também sugere que em outras faixas de $\mathrm{pH}$ o comportamento da cinética de degradação é 
diferenciado, uma vez que, por exemplo, em pH 11,0 para o corante amarelo a remoção de cor foi de $14,12 \pm 2,60 \%$ enquanto para o corante azul esta corresponde a $84,61 \pm 2,50 \% \%$.

Os resultados obtidos para a remoção de cor pelo processo de degradação fotoquímica na faixa de $\mathrm{pH} 4,0$, em todos os casos, os valores são maiores que $91,12 \pm 0,95 \%$ (Tabela 24), níveis bastante aceitáveis, tornando este efluente apropriado para reuso em $95 \%$ dos processos de beneficiamentos têxteis (ROSA, 2010).

O processo de degradação executado no efluente produzido com a tricromia selecionada apresentou comportamentos de degradação fotoquímica muito semelhante aos efluentes gerados dos processos de tingimentos com os corantes individuais (Figura 31).

Foi possível também observar que o corante azul Drimaren HF-RL se mostrou mais suscetível ao tratamento (Tabela 24), uma vez que este apresentou valores de remoção muito semelhantes nas três faixas de $\mathrm{pH}$, este resultado pode indicar que este corante apresenta menor resistência a oxidação e isto pode ser explicado provavelmente em função da sua complexidade composicional (SALGADO et al., 2009).

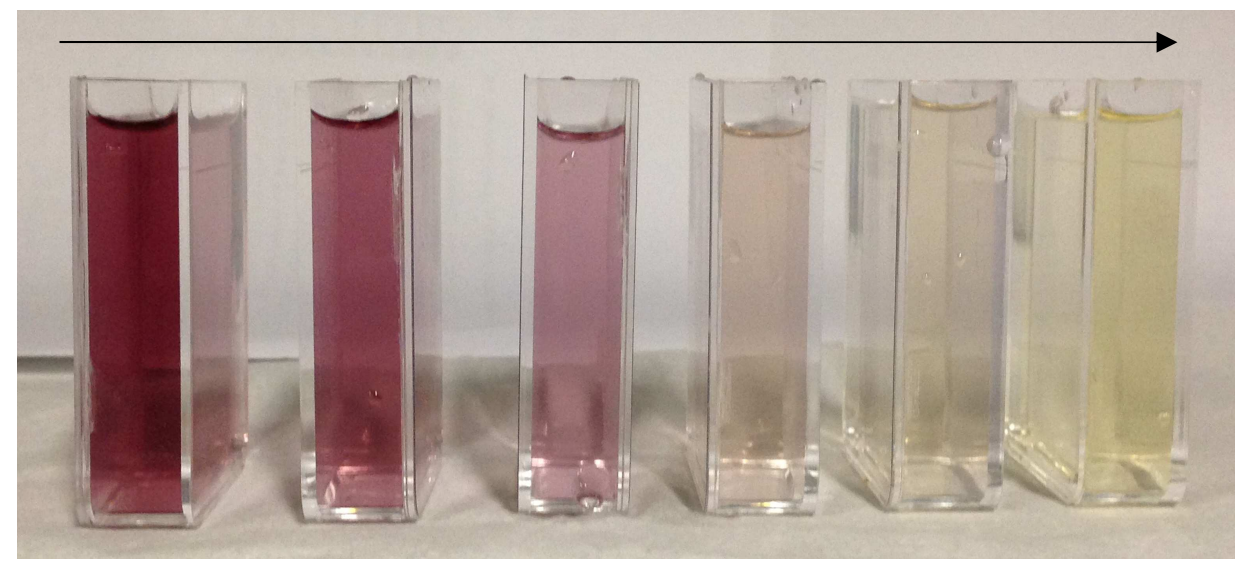

Figura 31 - Resultado da decomposição fotoquímica do efluente produzido com a tricromia estudada por $270 \mathrm{~min}$. 


\subsection{Tingimentos utilizando os efluentes tratados pelo processo $\mathrm{UV} / \mathrm{H}_{2} \mathrm{O}_{2}$}

As águas dos efluentes tratados foram utilizadas para realizar um novo processo de tingimento, conforme descrito no item 4.2.1.

Os resultados da Figura 32 mostram o comportamento de degradação para o primeiro, segundo e terceiro tratamento realizados com a água de reuso.

Foi possível observar que a medida que os efluentes são tratados, estes apresentam uma coloração residual (Figura 32), isto pode ser explicado pelos cálculos de rendimento. O primeiro tratamento fotoquímico, apresentou eficiência de $91,12 \pm 0,95 \%$ (Tabela 24), considerando um rendimento de $100 \%$ de eficiência, foi possível concluir que $8,88 \pm 0,95 \%$ de cor manteve-se na água tratada (Tabela 25 ).

Para o segundo e terceiro tratamento as porcentagens acumuladas foram de $17,99 \pm 0,14 \%$ e $29,67 \pm 0,51 \%$ respectivamente (Tabela 25 ).

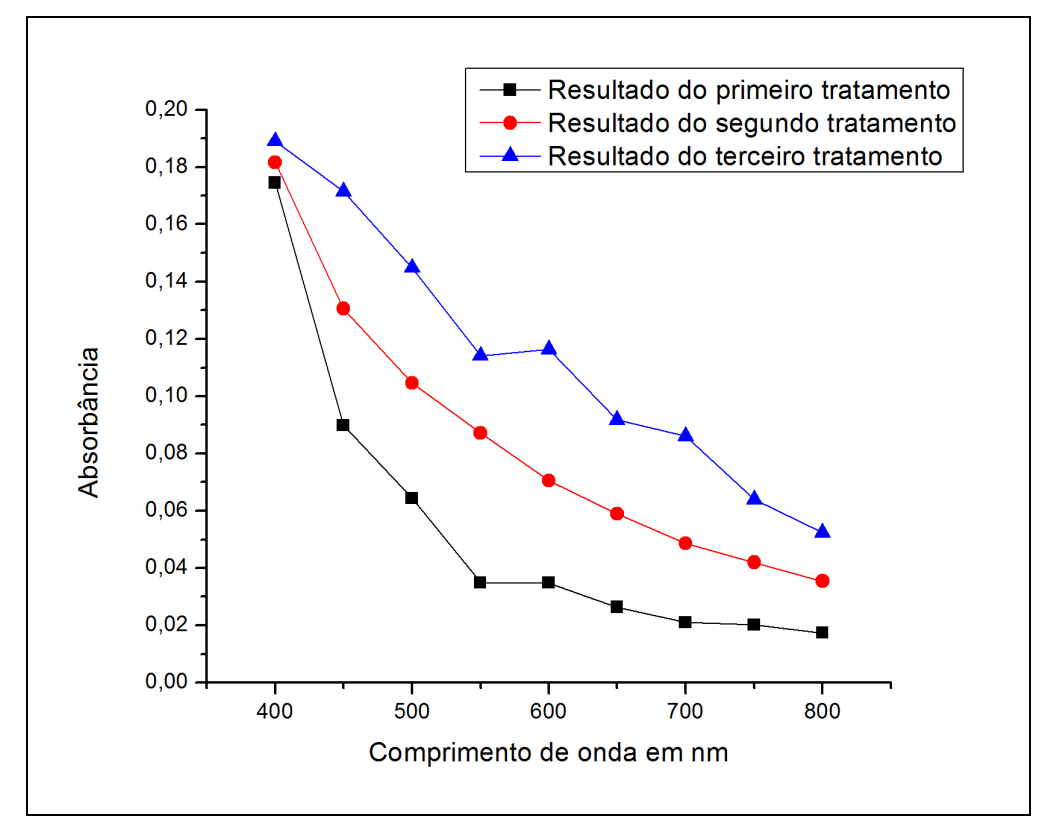

Figura 32 - Variação das absorbâncias dos efluentes tratados nas faixas UV e visível em função do comprimento de onda nm com a tricromia estudada. 
Tabela 25 - Porcentagem remanescente de cor entre os tratamentos de degradação fotoquímica.

\begin{tabular}{ccc}
\hline Tratamento & $\begin{array}{c}\text { Absorbância na } \\
\text { faixa dos } 600 \mathbf{~ n m}\end{array}$ & $\begin{array}{c}\text { Remanescente } \\
(\%)\end{array}$ \\
\hline $\mathbf{1}^{\text {o }}$ & $0,0348 \pm 0,0035$ & $8,88 \pm 0,95$ \\
$\mathbf{2}^{\text {o }}$ & $0,0706 \pm 0,0005$ & $17,99 \pm 0,14$ \\
3o & $0,11640 \pm 0,0020$ & $29,67 \pm 0,51$ \\
\hline
\end{tabular}

Em função dos resultados obtidos (Figuras 32 e 33 e Tabelas 24, 25 e 26), foi possível concluir que conforme o processo fotoquímico foi realizado novamente sobre os efluentes, a eficiência da remoção de cor é normalmente a mesma, entretanto a pequena porcentagem de corante residual que resta dos tratamentos anteriores se acumula não permitindo que seja feito mais de três reusos, isto se deve ao controle de qualidade utilizado pela indústria têxtil que determina a aprovação ou reprovação de cor por meio de leituras de reflectância que definem o $\Delta \mathrm{E}$ ( diferenças de cor), conforme citado no item 2.1.7, deste trabalho .

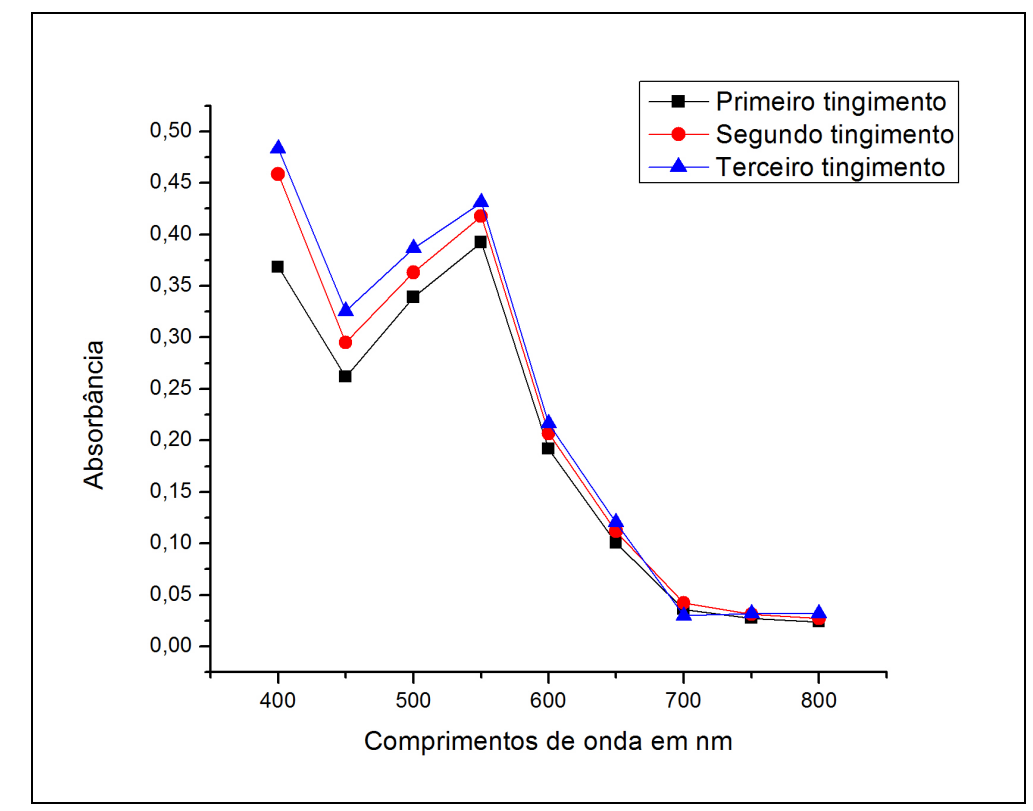

Figura 33 - Variação das absorbâncias dos efluentes gerados pelos tingimentos com água potável e de reuso tratada por processo fotoquímico com $\mathrm{H}_{2} \mathrm{O}_{2} / \mathrm{UV}$ nas faixas UV e visível em função do comprimento de onda nm com a tricromia estudada. 
Tabela 26 - Comparativo da coloração residual entre os efluentes produzidos com água de reuso.

\begin{tabular}{ccc}
\hline Efluente & $\begin{array}{c}\text { Absorbância na } \\
\text { faixa dos } 550 \mathrm{~nm}\end{array}$ & $\begin{array}{c}\text { Coloração residual do } \\
\text { processo de tratamento } \\
\text { fotoquímico com } \mathrm{H}_{2} \mathrm{O}_{2} / \mathrm{UV} \\
(\%)\end{array}$ \\
\hline $\begin{array}{c}\text { Proveniente do } \\
\text { tingimento } \\
\text { padrão }\end{array}$ & $0,3921 \pm 0,0004$ & --- \\
$\begin{array}{c}\text { Proveniente do } \\
\text { tingimento com 10 } \\
\text { água de reuso }\end{array}$ & $0,4176 \pm 0,0056$ & $6,52 \pm 0,12$ \\
$\begin{array}{c}\text { Proveniente do } \\
\text { tingimento com } \mathbf{2}^{\mathrm{O}}\end{array}$ & $0,4310 \pm 0,0011$ & \\
água de reuso & & $9,94 \pm 0,03$ \\
\hline
\end{tabular}

Esta água de reuso não seria recomendada para aplicação em novos processos de tingimentos, no entanto poderiam ser propostos outras aplicações que não exija potabilidade, tais como limpeza de chão ou água para abastecimento de vasos sanitários, mediante a análises de toxidade que devem ser executadas anteriormente.

Neste trabalho foi mostrado a influência da variação do $\mathrm{pH}$ no processo de

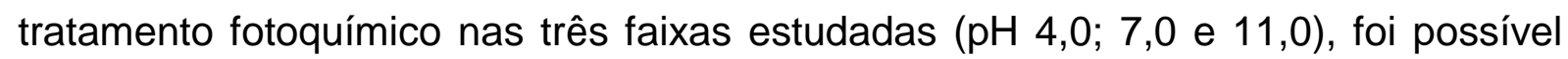
fazer uma análise sucinta desta variação. A Tabela 27 mostra que em meio alcalino a variação de $\mathrm{pH}$ se torna maior, inclusive é permitido avaliar que para o corante amarelo Drimaren CL-2R, esta diferença é significativa (25,45\%), ao passo que, para os corantes vermelho Drimaren CL-2R e azul Drimaren HF-RL, estes são em média de $11,0 \%$ (sendo $11,36 \%$ para o vermelho e $10,14 \%$ para o azul), com isto concluise que o comportamento de degradação destes dois últimos corantes citados são muito semelhantes, isto inclusive foi confirmado quando se avalia a porcentagem de remoção de cor para os mesmos, que em pH alcalino são significativas $(69,36 \pm$ 
0,87\% e 84,61 $\pm 2,50 \%$ respectivamente) conforme Tabela 24 . O comportamento de degradação do corante amarelo é muito inferior aos dois, sendo de 14,12 $\pm 2,60 \%$ (Tabela 24).

A tricromia possui comportamento muito semelhante em relação à redução de $\mathrm{pH}$ e porcentagem de remoção de cor (Tabela 24 e 27) com os corantes vermelho e azul, isto pode ser justificado pelo fato de que a somatória da porcentagem de concentração de corantes, estes somam juntos $0,8 \%$ contra os $0,4 \%$ do amarelo.

Também foi possível observar um decréscimo de $\mathrm{pH}$ durante o processo fotoquímico como demonstra a Tabela 27, a explicação para que este efeito ocorra pode ser devido a dois fatores, um é a formação de produtos intermediários originados durante o processo, podendo ser alguns ácidos orgânicos e a própria produção do ânion peroxila $\left(\mathrm{HO}_{2}^{-}\right)$e $\mathrm{H}^{+}$, provenientes da própria reação com o peróxido de hidrogênio (BALI et al., 2004; HASSEMER, 2006; MARMITT et al., 2010). 
Tabela 27 - Variações de pH após o processo fotoquímico com $\mathrm{H}_{2} \mathrm{O}_{2} / \mathrm{UV}$.

\begin{tabular}{lccc}
\hline Efluente Produzido & pH Inicial & pH Final & \% Redução \\
\hline Amarelo Drimaren CL-2R & 4,0 & 3,6 & 10,00 \\
Amarelo Drimaren CL-2R & 7,0 & 6,55 & 6,43 \\
Amarelo Drimaren CL-2R & 11,0 & 8,2 & 25,45 \\
Vermelho Drimaren CL-5B & 4,0 & 3,9 & 2,50 \\
Vermelho Drimaren CL-5B & 7,0 & 6,72 & 4,00 \\
Vermelho Drimaren CL-5B & 11,0 & 9,75 & 11,36 \\
Azul Drimaren HF-RL & 4,0 & 3,9 & 2,50 \\
Azul Drimaren HF-RL & 7,0 & 6,78 & 3,14 \\
Azul Drimaren HF-RL & 11,0 & 9,5 & 10,14 \\
$\begin{array}{l}\text { Tricromia com corantes } \\
\text { Drimaren }\end{array}$ & 4,0 & 3,9 & 2,5 \\
$\begin{array}{l}\text { Tricromia com corantes } \\
\text { Drimaren }\end{array}$ & 7,0 & 6,8 & 9,86 \\
$\begin{array}{l}\text { Tricromia com corantes } \\
\text { Drimaren }\end{array}$ & 11,0 & 9,8 & 10,91 \\
\hline & & & \\
\hline
\end{tabular}

\subsubsection{Influência da condutividade}

O efluente produzido com corantes reativos tende a ter altos valores de condutividade, uma vez que para o processo de tingimento são requeridas grandes concentrações de eletrólitos e, podendo este valor atingir a ordem de até 90 g.L-1, isto irá depender da cor a ser tinta (BELTRAME, 2000).

A condutividade também se mostrou um item importante no processo fotoquímico, ao término do processo de degradação dos efluentes analisados foi observado que, houve um pequeno decréscimo na condutividade entre os pHs 4,0 e 7,0; contudo no pH 11,0 estas variações foram consistentes, devido ao fato já citado 
anteriormente, indica que houveram quebras das moléculas orgânicas existentes no efluente (MARMITT et al., 2010; MACHADO e STÜLP, 2013).

Conhecer o valor de condutividade da água de reuso foi um parâmetro considerável para tornar possível o aproveitamento do eletrólito presente nesta água tratada e com isto permitir o cálculo das quantidades necessárias de cloreto ou sulfato de sódio reduzindo desta forma o consumo destes reagentes durante os processos de tingimento posteriores. A equação da reta obtida na curva de calibração do item 4.2.3 foi utilizada para calcular as novas concentrações de cloreto de sódio a partir das leituras de condutividade nas amostras. As Tabelas 28, 29 e 30 mostram as leituras de condutividade inicial e final para os efluentes gerados com os três corantes isoladamente, os resultados demonstram que as variações de condutividade para os primeiros tratamentos são muito pequenas, pode-se avaliar que estas diferenças são geradas em função do ácido ou álcali utilizado para correção de $\mathrm{pH}$. Contudo para os segundos tratamentos esta condutividade altera significativamente e com isto torna possível quantificar a quantidade de eletrólito residual no banho (Tabelas 28,29 e 30 ).

Os novos tingimentos com a água de reuso permitiram uma economia de eletrólito de até 3,22 g.L-1, 7,59 g.L-1, 4,31 g.L-1 (Tabelas 28, 29 e 30), para os tingimentos com corantes amarelo, vermelho e azul respectivamente.

Estes valores de economia de cloreto de sódio ou sulfato de sódio, a primeiro momento pode parecer irrisório, uma vez que estes produtos são insumos baratos, entretanto, se considerarmos uma máquina industrial que processa em média 500 $\mathrm{Kg}$ de tecido e se utiliza uma relação de banho de 1:10, ou seja, totalizando 5000L, esta economia será de $6,90 \mathrm{Kg}, 12,30 \mathrm{Kg}$ e 23,45 Kg

Ainda se tratando a respeito das vantagens obtidas pelo reaproveitamento do cloreto de sódio, mesmo este sendo um insumo barato, considerando que o preço médio de mercado é aproximadamente $R \$ 1,20$, a economia financeira proporcionada para os corantes tintos individualmente pode alcançar até $R \$ 29,58$, enquanto a tricromia permite que este valor chegue à $R \$ 28,14$, estes dados são demonstrados nas Tabelas 32 e 33.

Em relação ao tratamento dos efluentes gerados com o tingimento da tricromia, o comportamento da condutividade foi muito semelhante ao processo 
executado nos tingimentos com os corantes individuais, a variação de condutividade também foi pequena (Tabela 31), e esta pode ser decorrida também da utilização de ácidos ou álcalis para correção de $\mathrm{pH}$.

Em relação a utilização da água de reuso, a Tabela 31 demonstra que desde o primeiro reuso é possível se aproveitar o eletrólito presente no banho, com o segundo e terceiro tratamento, esta economia é mais significativa, uma vez que no

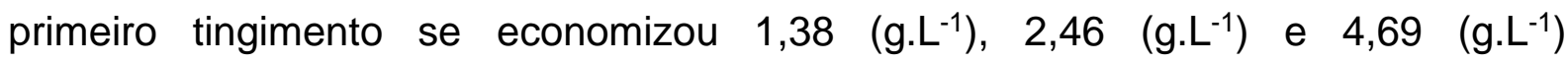
respectivamente.

Tabela 28 - Correção do cloreto de sódio em função da curva de calibração da condutividade da água de reuso proveniente do tingimento com corante amarelo Drimaren CL-2R

\begin{tabular}{lllll}
\hline Efluente Produzido & Condutividade & Condutividade & Quantidade & \% Redução \\
& Inicial $(\mathrm{ms} / \mathrm{cm})$ & Final $(\mathrm{ms} / \mathrm{cm})$ & de cloreto \\
& & de sódio & \\
& & corrigida
\end{tabular}

(g. $\left.L^{-1}\right)$

\begin{tabular}{|c|c|c|c|c|}
\hline $\begin{array}{l}\text { Amarelo Drimaren } \\
\text { CL-2R em pH 4,0 - } \\
\text { 10 tratamento }\end{array}$ & $1,8600 \pm 0,0981$ & $1,8330 \pm 0,0981$ & $63,29 \pm 2,90$ & $2,63 \pm 0,07$ \\
\hline $\begin{array}{l}\text { Amarelo Drimaren } \\
\text { CL-2R em pH 7,0 - } \\
\text { 1 tratamento }\end{array}$ & $1,8600 \pm 0,0981$ & $1,6250 \pm 0,0382$ & $64,05 \pm 1,51$ & $1,46 \pm 0,03$ \\
\hline $\begin{array}{l}\text { Amarelo Drimaren } \\
\text { CL-2R em pH } 11,0 \\
-1 \% \text { tratamento }\end{array}$ & $1,8600 \pm 0,0981$ & $1,4620 \pm 0,0113$ & $64,15 \pm 0,50$ & $1,31 \pm 0,01$ \\
\hline $\begin{array}{l}\text { Amarelo Drimaren } \\
\text { CL-2R em pH } 4,0 \text { - } \\
2 \% \text { tratamento }\end{array}$ & $3,6120 \pm 0,0437$ & $3,5860 \pm 0,0478$ & $62,91 \pm 0,83$ & $3,22 \pm 0,04$ \\
\hline
\end{tabular}

Obs.: Concentração inicial de cloreto de sódio foi de $65 \mathrm{~g} . \mathrm{L}^{-1}$. 
Tabela 29 - Correção do cloreto de sódio em função da curva de calibração da condutividade da água de reuso proveniente do tingimento com corante vermelho Drimaren CL-5B

\begin{tabular}{|c|c|c|c|c|}
\hline Efluente Produzido & $\begin{array}{l}\text { Condutividade } \\
\text { Inicial (ms/cm) }\end{array}$ & $\begin{array}{l}\text { Condutividade } \\
\text { Final (ms/cm) }\end{array}$ & $\begin{array}{l}\text { Quantidade de } \\
\text { cloreto de sódio } \\
\text { corrigida }\left(g \cdot \mathrm{L}^{-1}\right)\end{array}$ & $\begin{array}{c}\% \\
\text { Redução }\end{array}$ \\
\hline $\begin{array}{l}\text { Vermelho } \\
\text { Drimaren CL-5B } \\
\text { em pH } 4,0-1^{\circ} \\
\text { tratamento }\end{array}$ & $3,3600 \pm 0,0653$ & $3,3270 \pm 0,0445$ & $63,07 \pm 0,85$ & $2,97 \pm 0,04$ \\
\hline $\begin{array}{l}\text { Vermelho } \\
\text { Drimaren CL-5B } \\
\text { em pH 7,0 - 1을 } \\
\text { tratamento }\end{array}$ & $3,3600 \pm 0,0653$ & $3,0800 \pm 0,0163$ & $63,21 \pm 0,33$ & $2,75 \pm 0,02$ \\
\hline $\begin{array}{l}\text { Vermelho } \\
\text { Drimaren CL-5B } \\
\text { em pH 11,0-1을 } \\
\text { tratamento }\end{array}$ & $3,3600 \pm 0,0653$ & $2,9750 \pm 0,0570$ & $63,27 \pm 1,21$ & $2,66 \pm 0,05$ \\
\hline Vermelho & $8,5050 \pm 0,0829$ & $8,4750 \pm 0,1187$ & $60,07 \pm 0,85$ & $7,59 \pm 0,11$ \\
\hline 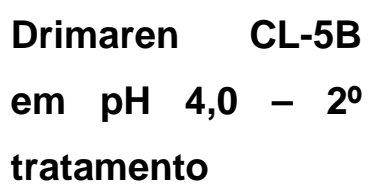 & & & & \\
\hline
\end{tabular}


Tabela 30 - Correção do cloreto de sódio em função da curva de calibração da condutividade da água de reuso proveniente do tingimento com corante azul Drimaren HF-RL

\begin{tabular}{|c|c|c|c|c|}
\hline $\begin{array}{l}\text { Efluente } \\
\text { Produzido }\end{array}$ & $\begin{array}{l}\text { Condutividade } \\
\text { Inicial (ms/cm) }\end{array}$ & $\begin{array}{l}\text { Condutividade } \\
\text { Final (ms/cm) }\end{array}$ & $\begin{array}{l}\text { Quantidade de } \\
\text { cloreto de sódio } \\
\text { acrescentadas } \\
\left(g . \mathrm{L}^{-1}\right)\end{array}$ & $\begin{array}{c}\text { \% Redução de } \\
\text { cloreto de } \\
\text { sódio no } \\
\text { tingimento }\end{array}$ \\
\hline $\begin{array}{l}\text { Azul Drimaren } \\
\text { HF-RL em } \\
\begin{array}{l}4,0 \quad-\quad 10 \\
\text { tratamento }\end{array}\end{array}$ & $1,723 \pm 0,0316$ & $1,694 \pm 0,0361$ & $64,02 \pm 1,36$ & $1,51 \pm 0,03$ \\
\hline 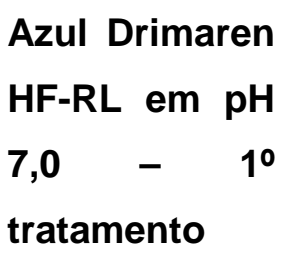 & $1,723 \pm 0,0316$ & $1,624 \pm 0,0984$ & $64,05 \pm 3,88$ & $1,46 \pm 0,07$ \\
\hline $\begin{array}{l}\text { Azul Drimaren } \\
\text { HF-RL em } \\
\begin{array}{l}11,0 \quad- \\
\text { tratamento }\end{array}\end{array}$ & $1,723 \pm 0,0316$ & $1,642 \pm 0,0687$ & $64,04 \pm 2,68$ & $1,48 \pm 0,05$ \\
\hline $\begin{array}{l}\text { Azul Drimaren } \\
\text { HF-RL em } \mathrm{pH} \\
4,0 \quad-\quad 2^{\circ} \\
\text { tratamento }\end{array}$ & $4,855 \pm 0,0694$ & $4,738 \pm 0,0739$ & $62,2 \pm 0,95$ & $4,31 \pm 0,07$ \\
\hline
\end{tabular}


Tabela 31 - Correção do cloreto de sódio em função da curva de calibração da condutividade da água de reuso proveniente do tingimento com tricromia de corantes Drimaren.

\begin{tabular}{|c|c|c|c|c|}
\hline $\begin{array}{l}\text { Efluente } \\
\text { Produzido }\end{array}$ & $\begin{array}{l}\text { Condutividade } \\
\text { Inicial } \\
(\mathrm{ms} / \mathrm{cm})\end{array}$ & $\begin{array}{l}\text { Condutividade } \\
\text { Final (ms/cm) }\end{array}$ & $\begin{array}{l}\text { Quantidade de } \\
\text { cloreto de sódio } \\
\text { acrescentadas } \\
\left(\mathrm{g} \cdot \mathrm{L}^{-1}\right)\end{array}$ & $\begin{array}{l}\text { \% Redução } \\
\text { de cloreto } \\
\text { de sódio no } \\
\text { tingimento }\end{array}$ \\
\hline $\begin{array}{l}\text { Tricromia com } \\
\text { corantes Drimaren } \\
\text { em pH } 4,0-1^{\circ} \\
\text { tratamento }\end{array}$ & $2,421 \pm 0,0168$ & $2,376 \pm 0,0787$ & $63,62 \pm 1,17$ & $2,12 \pm 0,04$ \\
\hline $\begin{array}{l}\text { Tricromia com } \\
\text { corantes Drimaren } \\
\text { em pH } 7,0-1^{\circ} \\
\text { tratamento }\end{array}$ & $2,421 \pm 0,0168$ & $2,304 \pm 0,0452$ & $63,65 \pm 0,74$ & $2,08 \pm 0,04$ \\
\hline $\begin{array}{l}\text { Tricromia com } \\
\text { corantes Drimaren } \\
\text { em pH } 11,0-19 \\
\text { tratamento }\end{array}$ & $2,421 \pm 0,0168$ & $2,396 \pm 0,0679$ & $63,60 \pm 1,80$ & $2,15 \pm 0,06$ \\
\hline $\begin{array}{l}\text { Tricromia com } \\
\text { corantes Drimaren } \\
\text { em pH } 4,0-2^{\circ} \\
\text { tratamento }\end{array}$ & $4,212 \pm 0,0140$ & $4,183 \pm 0,0688$ & $62,54 \pm 0,21$ & $3,79 \pm 0,01$ \\
\hline $\begin{array}{l}\text { Tricromia com } \\
\text { corantes Drimaren } \\
\text { em pH } 4,0-3^{\circ} \\
\text { tratamento }\end{array}$ & $8,064 \pm 0,0305$ & $8,008 \pm 0,0784$ & $60,31 \pm 0,59$ & $7,22 \pm 0,07$ \\
\hline
\end{tabular}


Tabela 32 - Estimativa de cálculo da economia financeira proveniente da correção do cloreto de sódio nos tingimentos com água de reuso com os corantes Drimaren utilizados individualmente.

\begin{tabular}{cclc}
\hline Efluente produzido & $\begin{array}{c}\text { Economia } \\
\text { de cloreto } \\
\text { de sódio }\end{array}$ & $\begin{array}{l}\text { Economia de cloreto de } \\
\text { sódio considerando }\end{array}$ & $\begin{array}{c}\text { Redução } \\
\text { equipamento utilizando }\end{array}$ \\
$(\mathrm{g} / \mathrm{L})$ & $\begin{array}{l}5000 \mathrm{~L} \text { como volume de } \\
\text { banho }(\mathrm{Kg})\end{array}$ & \\
& &
\end{tabular}

\section{Amarelo Drimaren}

CL-2R em pH 4,0 -

1,71

8,55

10,26

10 tratamento

Amarelo Drimaren

CL-2R em pH 4,0 -

2o tratamento

2,09

10,45

12,54

Vermelho

Drimaren CL-5B

em pH 4,0 - 10

1,93

9,65

11,58

tratamento

Vermelho

Drimaren CL-5B

em pH 4,0 - 2o

4,93

24,65

29,58

tratamento

Azul Drimaren HF-

RL em pH 4,0 - 1응

tratamento

0,98

4,90

5,88

Azul Drimaren HF-

RL em pH 4,0 - 2 tratamento

14,00

16,80

Obs.: Considerado uma máquina com capacidade produtiva de $500 \mathrm{Kg}$, volume de banho de $5000 \mathrm{~L}$ e preço médio do cloreto de sódio $R \$ 1,20$.

É importante ressaltar que os valores foram calculados para uma máquina de produção na qual irá processar $500 \mathrm{Kg}$, ou seja, esta economia remete a cada tingimento. Se a mesma fizer 2 tingimentos por dia, os valores obtidos nas Tabelas 32 e 33 irão dobrar, e se ainda, considerarmos que esta máquina venha executar o 
mesmo processo durante 22 dias por mês, ao termino de um mês é possível ter uma economia de $\mathrm{R} \$ 1301,52$ para os tingimentos com corantes individualmente e $\mathrm{R} \$ 1238,16$ para os tingimentos da tricromia.

Tabela 33 - Estimativa de cálculo da economia financeira proveniente da correção do cloreto de sódio nos tingimentos com água de reuso utilizando a tricromia de corantes Drimaren estudados.

\begin{tabular}{|c|c|c|c|}
\hline Efluente produzido & $\begin{array}{l}\text { Economia } \\
\text { de cloreto } \\
\text { de sódio } \\
\text { (g/L) }\end{array}$ & $\begin{array}{l}\text { Economia de cloreto de } \\
\text { sódio considerando } \\
\text { equipamento utilizando } \\
5000 \mathrm{~L} \text { como volume de } \\
\text { banho }(\mathrm{Kg})\end{array}$ & $\begin{array}{l}\text { Redução } \\
\text { de cada } \\
\text { etapa do } \\
\text { reuso } \\
\text { (R\$) }\end{array}$ \\
\hline 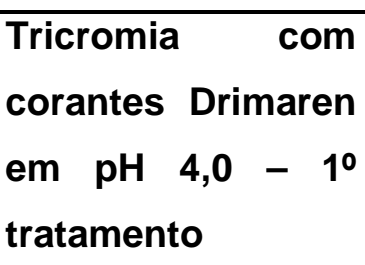 & 1,38 & 6,90 & 8,28 \\
\hline $\begin{array}{l}\text { Tricromia com } \\
\text { corantes Drimaren } \\
\text { em pH } 4,0-2^{\circ} \\
\text { tratamento }\end{array}$ & 2,46 & 12,30 & 14,76 \\
\hline $\begin{array}{l}\text { Tricromia com } \\
\text { corantes Drimaren } \\
\text { em pH 4,0 - 3o } \\
\text { tratamento }\end{array}$ & 4,69 & 23,45 & 28,14 \\
\hline
\end{tabular}

\subsubsection{Carbono total orgânico}

Foram submetidos à análise para quantificação de carbono total orgânico tanto para os efluentes gerados dos processos de tingimento quanto dos seus respectivos reusos. 
Estes ensaios têm por finalidade avaliar se o processo fotoquímico foi eficiente também na destruição de carga orgânica, uma vez que este já se provou eficaz na degradação dos cromóforos contidos nas moléculas dos corantes, mas não significa que estes foram transformados em compostos com menor grau de toxidade. A Tabela 34 mostra os resultados do decréscimo do carbono total orgânico demonstra que houve mineralização de parte da matéria orgânica (ROCHA et al, 2012; BRUNELLI et al, 2009).

A Tabela 34 demonstra que o processo de degradação fotoquímica também é eficiente a respeito da degradação de compostos orgânicos, no primeiro tratamento do efluente produzido, observa-se que este proporcionou uma eficiência de $27,86 \%$, no segundo, esta eficiência sobe para $43,22 \%$.

Entretanto para o terceiro tratamento foi possível observar que esta remoção de carga orgânica decai significamente para 14,04\% (Tabela 34), isto pode ser o fator que inviabiliza o reuso desta água para um próximo tingimento (Tabela 38).

Um segundo fator que pode interferir no aumento da carga orgânica do efluente gerado do primeiro processo de tingimento para o segundo que foi executado com a primeira água de reuso, o qual apresentou um aumento da carga orgânica de mais que quatro vezes (Tabela 34), pode ser devido não apenas aos corantes que são adicionados durante o novo processo de tingimento, mas também os agentes auxiliares tais como sequestrante e detergente para lavagem utilizados no processo. 
Tabela 34- Resultados do decréscimo de COT durante o processo de tratamento com $\mathrm{H}_{2} \mathrm{O}_{2}$.

\begin{tabular}{|c|c|c|c|c|}
\hline $\begin{array}{l}\text { Efluentes } \\
\text { gerados }\end{array}$ & $\begin{array}{l}\text { Carbono } \\
\text { orgânico total } \\
\text { inicial (ppm) }\end{array}$ & $\begin{array}{l}\text { Amostras após } \\
\text { o tratamento } \\
\text { com } \mathrm{H}_{2} \mathrm{O}_{2} / \mathrm{UV}\end{array}$ & $\begin{array}{l}\text { Carbono } \\
\text { orgânico total } \\
\text { final }(p p m)\end{array}$ & $\begin{array}{l}\text { Redução } \\
\text { COT }\end{array}$ \\
\hline $\begin{array}{l}\text { Efluente gerado } \\
\text { pelo } 1^{\circ} \\
\text { tingimento }\end{array}$ & 11860,0 & 1ำ Tratamento & 8556,0 & 27,86 \\
\hline $\begin{array}{l}\text { Efluente gerado } \\
\text { pelo tingimento } \\
\text { com a } 1^{\circ} \text { água } \\
\text { de reuso }\end{array}$ & 46670,0 & $2^{\circ}$ Tratamento & 26500,0 & 43,22 \\
\hline $\begin{array}{l}\text { Efluente gerado } \\
\text { pelo tingimento } \\
\text { com a } 2^{\circ} \text { água } \\
\text { de reuso }\end{array}$ & 71560,0 & 3ำTratamento & 61510,0 & 14,04 \\
\hline
\end{tabular}

\subsection{Avaliação da cor dos tingimentos executados com água de reuso produzida pelo processo de oxidação avançada $\mathrm{H}_{2} \mathrm{O}_{2} / \mathrm{UV}$.}

Para análise do tingimento com a água de reuso produzida pelo processo de oxidação avançada $\mathrm{H}_{2} \mathrm{O}_{2} / \mathrm{UV}$, foi utilizado o valor de $\Delta \mathrm{E}$, que é a diferença de cor no espaço CMC conforme descrito no item 2.1.7.

Considerando a iluminante $\mathrm{D} 65$, os valores obtidos de $\Delta \mathrm{E}$ para o corante amarelo Drimaren CL-2R no primeiro e segundo tingimento com as águas de reuso geradas pelo processo fotoquímico foram 0,62 , e 0,58 respectivamente (Tabela 35). Analisando a Tabela 35, as amostras tingidas com a primeira e segunda água de reuso do respectivo corante foi possível perceber que estas estão mais escuras, uma vez que houve um decréscimo da luminosidade $\left(\Delta L^{*}\right)$ em ambas, de - 0,21 e 0,39 , a amostra tinta com o $1^{\circ}$ reuso se mostrou menos avermelhada $\left(\Delta \mathrm{a}^{*}=-0,12\right)$ e mais amarelada $\left(\Delta \mathrm{b}^{*}=1,43\right)$, já a amostra tinta com o $2^{\circ}$ reuso se apresentou mais vermelhada $\left(\Delta \mathrm{a}^{*}=1,31\right)$ e um pouco mais amarelada $\left(\Delta \mathrm{b}^{*}=0,16\right)$, esta análise foi feita em função do item 2.1.7 e Figura 10 . 
Tabela 35 - Resultados da leitura da cor dos tingimentos executados com as águas de reuso com o corante amarelo Drimaren CL-2R.

\begin{tabular}{|c|c|c|c|c|}
\hline & & \multicolumn{3}{|c|}{ Amarelo Drimaren CL-2R } \\
\hline & Padrão & $\begin{array}{c}\text { Amostra } \\
\text { tingida com 1ํㅡㄴ } \\
\text { reuso. }\end{array}$ & Padrão & $\begin{array}{l}\text { Amostra } \\
\text { tingida } 2^{\circ} \\
\text { reuso. }\end{array}$ \\
\hline $\mathbf{L}^{*}$ & 74,71 & 74,50 & 74,71 & 74,32 \\
\hline$a^{*}$ & 26,91 & 26,79 & 26,91 & 28,22 \\
\hline $\mathbf{b}^{*}$ & 71,84 & 73,27 & 71,84 & 72,01 \\
\hline$C^{*}$ & 76,72 & 78,01 & 76,72 & 76,63 \\
\hline $\mathbf{h}^{\star}$ & 69,47 & 69,91 & 69,47 & 69,99 \\
\hline$\Delta \mathbf{L}^{*}$ & & $-0,21$ & & $-0,39$ \\
\hline$\Delta \mathbf{a}^{*}$ & & $-0,12$ & & 1,31 \\
\hline$\Delta \mathbf{b}^{*}$ & & 1,43 & & 0,16 \\
\hline$\Delta \mathbf{E}^{*}$ & & 0,62 & & 0,58 \\
\hline
\end{tabular}

Sendo que $L$ corresponde à luminosidade; eixo "a" as diferenças entre o verde e o vermelho; "b" as diferenças entre o amarelo e o azul e "h" corresponde à tonalidade da cor.

Para o corante vermelho Drimaren CL-5B (Tabela 36), as amostras presentaram os valores $\Delta \mathrm{E}$ foram 0,24 e 0,35 , para o primeiro e segundo tingimento com as águas de reuso. A primeira amostra apresentou uma diferença mínima a respeito de luminosidade $\left(\Delta L^{*}=0,04\right)$, entretanto no eixo $\Delta \mathrm{a}^{*}$, está se mostrou mais significativa, sendo de 0,55 , apontando que está mais avermelhada, já no eixo $\Delta b^{*}$ esta diferença foi de 0,21 , sinalizando que esta também se apresenta menos azulada (Figura 10); no segundo tingimento a diferença de intensidade se mostrou maior $\left(\Delta L^{*}=-0,62\right)$, sinalizando que a cor está mais clara, no eixo $\Delta \mathrm{a}^{*}$, foi de 0,17 
significando que está menos avermelhada, já no eixo $\Delta b^{*}$ esta diferença foi de 0,14 , indicando que a amostra está mais azulada (Figura 10).

Tabela 36 - Resultados da leitura da cor dos tingimentos executados com as águas de reuso com o corante vermelho Drimaren CL-5B.

\begin{tabular}{lcccc}
\hline & \multicolumn{4}{c}{ Vermelho Drimaren CL-5B } \\
\hline & Padrão & $\begin{array}{c}\text { Amostra } \\
\text { tingida com 10 } \\
\text { reuso. }\end{array}$ & Padrão & $\begin{array}{c}\text { Amostra } \\
\text { tingida com 20 } \\
\text { reuso. }\end{array}$ \\
& & & & \\
$\mathbf{L}^{*}$ & 48,31 & 48,35 & 48,31 & 48,93 \\
$\mathbf{a}^{*}$ & 58,20 & 58,75 & 58,20 & 58,03 \\
$\mathbf{b}^{*}$ & $-5,14$ & $-4,92$ & $-5,14$ & $-5,50$ \\
$\mathbf{C}^{*}$ & 58,43 & 58,08 & 58,43 & 58,29 \\
$\mathbf{h}^{*}$ & 354,95 & 366,21 & 354,95 & 354,59 \\
$\Delta \mathbf{L}^{*}$ & & 0,04 & & $-0,62$ \\
$\Delta \mathbf{a}^{*}$ & & 0,55 & & 0,17 \\
$\Delta \mathbf{b}^{*}$ & & 0,21 & & 0,14 \\
$\Delta \mathbf{E}^{*}$ & & $\mathbf{0 , 2 4}$ & & $\mathbf{0 , 3 5}$ \\
\hline
\end{tabular}

Em relação aos tecidos tintos com o corante azul Drimaren HF-RL com as águas tratadas pelo processo de fotoquímico, os valores $\Delta \mathrm{E}$ foram 0,36 e 0,56 (Tabela 37), a primeira amostra apresentou um aumento de luminosidade, demonstrando que está se encontra mais clara $\left(\Delta L^{*}=0,70\right)$, entretanto nos eixos $\Delta \mathrm{a}^{*}$ e $\Delta b^{*}$ os valores são mínimos $-0,07$ e 0,06 , levando a concluir que a diferença significativa é a do eixo da luminosidade (Figura 10). A segunda amostra demonstra estar mais escura $\left(\Delta L^{*}=0,24\right)$, no eixo $\Delta \mathrm{a}^{*}$, o resultado foi $-0,26$, permitindo concluir que está menos esverdeada e o valor do eixo $\Delta b^{*}$ que foi 1,01 define que está mais amarelada Figura 10. 
Tabela 37 - Resultados da leitura da cor dos tingimentos executados com as águas de reuso com o corante azul Drimaren HR-RL.

\begin{tabular}{lcccc}
\hline & \multicolumn{4}{c}{ Azul Drimaren HF-RL } \\
\hline & Padrão & $\begin{array}{c}\text { Amostra } \\
\text { tingida com 10 } \\
\text { reuso. }\end{array}$ & Padrão & $\begin{array}{c}\text { Amostra } \\
\text { tingida com 20 } \\
\text { reuso. }\end{array}$ \\
& & 41,62 & 40,93 & 40,69 \\
$\mathbf{L}^{*}$ & 40,93 & $-0,81$ & $-0,74$ & $-0,48$ \\
$\mathbf{a}^{*}$ & $-0,74$ & $-30,78$ & $-30,84$ & $-31,85$ \\
$\mathbf{b}^{*}$ & $-30,84$ & 30,79 & 30,85 & 31,83 \\
$\mathbf{C}^{*}$ & 30,85 & 368,62 & 269,69 \\
$\mathbf{h}^{*}$ & 268,62 & 268,49 & 269 & 0,24 \\
$\Delta \mathbf{L}^{*}$ & & 0,70 & & $-0,26$ \\
$\Delta \mathbf{a}^{*}$ & & $-0,07$ & & $+1,01$ \\
$\Delta \mathbf{b}^{*}$ & & 0,06 & & $\mathbf{0 , 5 6}$ \\
$\Delta \mathbf{E}^{*}$ & & $\mathbf{0 , 3 6}$ & & \\
\hline
\end{tabular}

A magnitude de $\Delta \mathrm{E}$ informa 0 tamanho da diferença total, mas não indica 0 caráter da diferença da cor, ou seja, não indica a quantidade relativa e a direção das diferenças de luminosidade, croma e matiz. Estas informações só podem ser obtidas se cada uma das componentes que formam o $\Delta \mathrm{E}$ forem analisados isoladamente, ou seja, é necessário avaliar a luminosidade e os valores nos eixos $a^{*}$ e $b^{*}$ conforme demonstrado na Figura 10 (GOVEIA, 2004).

O comportamento dos tecidos tintos com a tricromia estudada utilizando as águas de reuso estão descritos na Tabela 38, onde a amostra tinta com a primeira água de reuso apresenta $\Delta \mathrm{E}$ de $0,25, \circ \Delta \mathrm{L}^{*}$ foi de $-0,14$ estabelecendo que a amostra está mais escura, os valores nos eixos $\Delta a^{*}$ e $\Delta b^{*}$ foram $-0,11$ e 0,13 , com isto indica que está um pouco avermelhada e amarelada (Figura 10). A amostra tinta com a segunda água de reuso mostrou $\Delta \mathrm{E}$ de 0,47 , o tecido neste caso, estava mais 
claro $\left(\Delta L^{*}=0,30\right)$, os valores nos eixos $\Delta a^{*}$ e $\Delta b^{*}$ foram 0,24 e 0,34 , remetendo a uma cor mais avermelhada e mais amarelada (Figura 10).

Como foi possível observar em função dos resultados obtidos no tingimento da tricromia de corantes (Tabela 38), as diferenças entre os eixos L, a e b são muito semelhantes, a segunda amostra apresenta um comportamento muito parecido com a primeira, apenas aumentando um pouco as diferenças de cor $(\Delta \mathrm{E})$ que foi de 0,25 para 0,47 .

Considerando que os valores de $\Delta \mathrm{E}$ comentados até 0 momento são inferiores a 0,62 (Tabelas 35, 36, 37 e 38), mediante a isto, atestam que para indústria de confecção estes são completamente aceitáveis.

Já a terceira amostra tinta apresentou um resultado diferente das duas anteriores, o $\Delta \mathrm{E}$ foi de 2,28, o qual é considerado muito alto, uma vez que conforme o item 2.1.7, as diferenças de cor aceitáveis para a indústria de confecção estão entre 0,8 a 1,2. A maior diferença encontrada na mesma se deu no eixo $\Delta b^{*}$ que foi 1,49 , acusando que a mesma está mais azulada e menos amarelada, o $\Delta \mathrm{a}^{*}$ foi de 0,57 , com isto está mais avermelhada e o $\Delta L^{*}$ de 0,40 , analisando-a mais escura (Figura 10).

Em função do $\Delta \mathrm{E}$ da amostra tinta com a terceira água de reuso ter sido considerado alto $(\Delta \mathrm{E}=2,28)$, foi concluído que para a utilização desta em novo tingimento, é ideal que esta seja tratada duas vezes apenas, inclusive este resultado também é confirmado pelos resultados de COT (Tabela 34), entretanto nada impede que esta água após o terceiro tratamento seja usada para outras aplicações tais como limpeza de pisos, vasos sanitários, etc. 
Tabela 38 - Resultados da leitura da cor dos tingimentos executados com as águas de reuso com a tricromia estudada.

Tricromia com os corantes Amarelo Drimaren CL-2R Vermelho Drimaren CL-5B Azul HF-RL

\begin{tabular}{|c|c|c|c|c|c|c|}
\hline & Padrão & $\begin{array}{l}\text { Amostra } \\
\text { tingida com } 1^{\circ} \\
\text { reuso. }\end{array}$ & Padrão & $\begin{array}{c}\text { Amostra } \\
\text { tingida com } 2^{\circ} \\
\text { reuso. }\end{array}$ & Padrão & $\begin{array}{c}\text { Amostra } \\
\text { tingida com 3ㅇ } \\
\text { reuso. }\end{array}$ \\
\hline$L^{*}$ & 40,47 & 40,32 & 40,47 & 40,77 & 40,47 & 40,07 \\
\hline$a^{*}$ & 7,01 & 6,90 & 7,01 & 7,25 & 7,01 & 7,58 \\
\hline $\mathbf{b}^{*}$ & 3,21 & 3,34 & 3,21 & 3,55 & 3,21 & 1,72 \\
\hline$C^{\star}$ & 7,71 & 7,66 & 7,71 & 8,07 & 7,71 & 8,17 \\
\hline $\mathbf{h}^{*}$ & 24,62 & 25,85 & 24,62 & 26,06 & 24,62 & 12,40 \\
\hline$\Delta \mathbf{L}^{*}$ & & $-0,14$ & & 0,30 & & 0,40 \\
\hline$\Delta \mathbf{a}^{*}$ & & $-0,11$ & & 0,24 & & 0,57 \\
\hline$\Delta \mathbf{b}^{*}$ & & 0,13 & & 0,34 & & 1,49 \\
\hline$\Delta \mathrm{E}^{\star}$ & & 0,25 & & 0,47 & & 2,28 \\
\hline
\end{tabular}

5.3.1 Testes de solidezes à cor

Conforme descrito no item 2.1.8 e 4.2.4, os testes de solidez à cor têm por função garantir a resistência das mesmas as diversas condições ao qual o substrato têxtil será exposto tais como lavagem, exposição a luz, à água clorada etc.

Para este trabalho foram executados ensaios de solidez a lavagem e a luz apenas nas amostras tintas com a tricromia, que representa os processos reais de uma indústria. 
Os resultados obtidos no ensaio de solidez da cor à lavagem, conforme a ABNT NBR ISO 105-C06, seguindo o procedimento da lavagem A1M estão descritos na Tabela 39.

Tabela 39 - Resultados do ensaio de solidez à lavagem aplicados nos tecidos tintos com a tricromia estudada.

Tricromia com os corantes Amarelo Drimaren CL-2R Vermelho Drimaren CL-5B Azul HF-RL

Solidez da cor à lavagem

Escala Cinza de Escala Cinza de Transferência de

Alteração de cor

cor

WO PAC PES PA CO CA

$\begin{array}{llllllll}\text { Padrão } & 4 / 5 & 4 / 5 & 5 & 5 & 5 & 5 & 5\end{array}$

1은 Tingimento com $\quad 4 / 5$

água de reuso

$\begin{array}{llllll}4 / 5 & 5 & 5 & 5 & 5 & 5\end{array}$

2o Tingimento com

$4 / 5$

água de reuso

$\begin{array}{llllll}4 / 5 & 5 & 5 & 5 & 5 & 5\end{array}$ acetato.

Sendo WO: lã; PAC: acrílico; PES: poliéster; PA: poliamida; CO: algodão; CA:

A amostra tinta com a primeira e segunda água de reuso apresentam os mesmos comportamentos da amostra padrão mediante ao teste de solidez a lavagem (Tabela 39).

Após os ensaios, os corpos-de-prova compostos (amostra ensaiada e tecidotestemunha) foram secos utilizando temperatura inferior à $60^{\circ} \mathrm{C}$, foi descosturado um dos lados da amostra e foi mantido apenas um lado costurado.

Foram avaliados por meio de comparação utilizando as escalas cinza de alteração e transferência de cor (Tabelas 14 e 15). Esta avaliação foi executada 
analisando comparativamente a diferença da amostra ensaiada com o tecido padrão (tecido não ensaiado) e a diferença do tecido testemunha ensaiado e o padrão. A diferença existente entre eles é comparada com a diferença existente entre cada nota da escala cinza de transferência e de alteração de cor, conforme descrito no item 4.2.4.

Avaliando o resultado de alteração de cor as três apresentaram notas 4/5 (Tabela 39), ou seja, determinando que houve uma pequena alteração entre a amostra padrão e a ensaiada (Tabela 14), mas que esta é devido características dos corantes e não em função da utilização da água proveniente do processo fotoquímico, caso contrário o tingimento padrão teria um desempenho diferente.

$\mathrm{Na}$ escala cinza de transferência de cor, os resultados mostram que as amostras tintas com a água de reuso apresentaram comportamentos semelhantes a amostra padrão, isto é, a transferência de cor de todas as amostras foram pequenas no tecido-testemunha de lã, uma vez que a nota foi $4 / 5$ e para as outras fibras não houveram transferência, nota 5 (Tabelas 15 e 39 e Figura 34).

Conforme os resultados obtidos no ensaio de solidez à lavagem (Tabela 39 e Figura 34), as notas apresentadas são excelentes, e ainda foi possível deduzir pelos ensaios que o tingimento com a água de reuso não interfere nos índices de solidez, uma vez que, apresentaram a mesma nota do tingimento padrão.

A Tabela 40 mostra os resultados da avaliação dos tecidos tintos com a tricromia no estudo realizado em relação à solidez a luz. Podemos observar que os tecidos tintos com a água de reuso e os tecidos do padrão apresentaram notas relativas a alteração de referência de cor pela escala azul no valor de 5 (Tabela 40 e Figuras 35 e 36), que corresponde a um valor de boa solidez a luz (Tabela 17). Em relação a escala cinza de alteração, a nota apresentada foi 4 para os três tecidos (Tabela 40 e Figura 35), que corresponde há uma pequena alteração da cor (Tabela 14 e também descrito no item 4.2.4).

O comportamento dos tecidos tintos com a água de reuso proveniente do processo fotoquímico foi o mesmo da amostra padrão quando submetido a influência da luz (Tabela 40 e Figura 35), ou seja, a água de reuso não interfere de forma alguma na solidez a luz. 


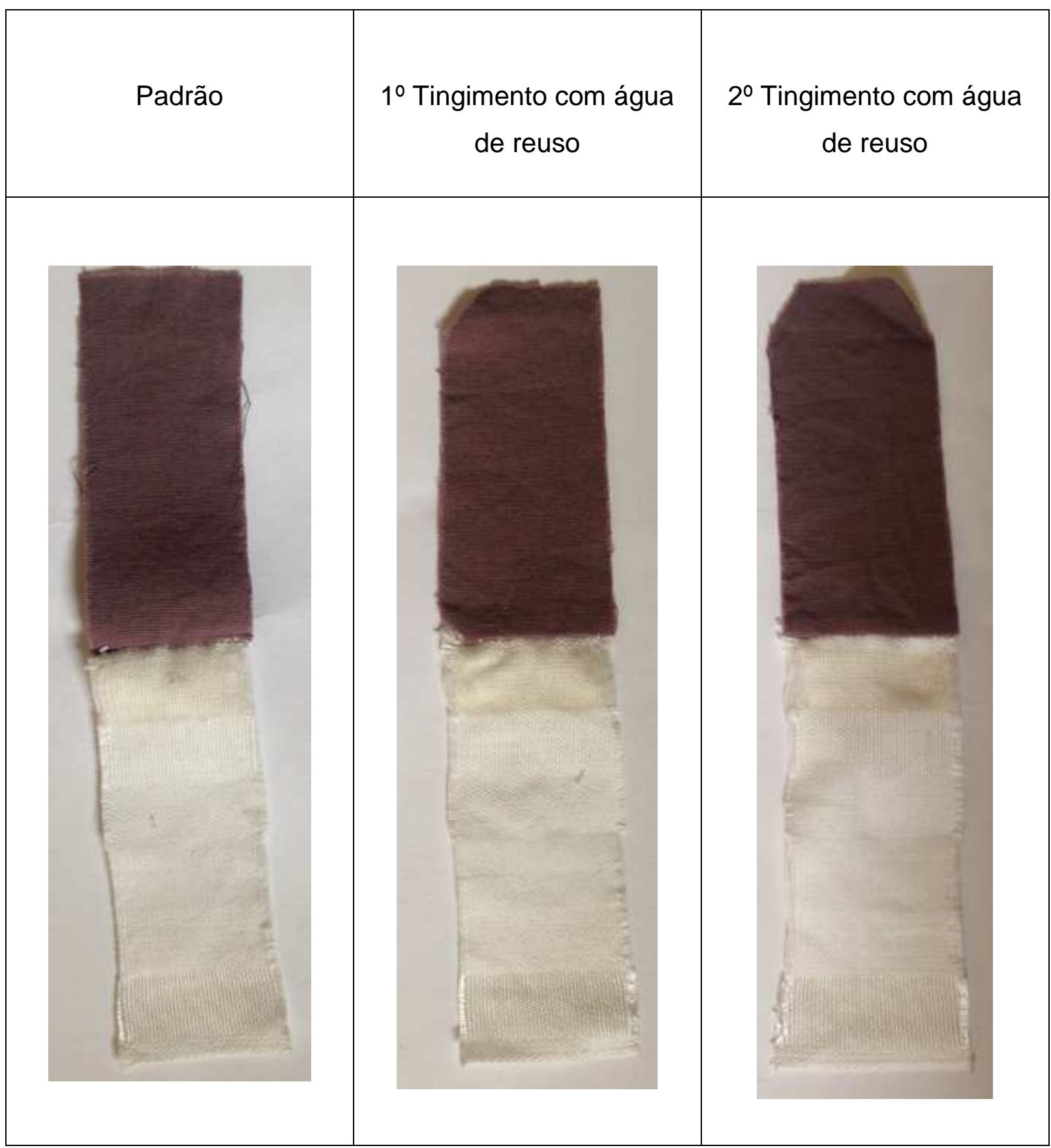

Figura 34- Corpos-de-prova compostos. 
Tabela 40 - Valores obtidos para ensaio de solidez da cor à luz dos tecidos tintos com a tricromia estudada

Tricromia com os corantes Amarelo Drimaren CL-2R Vermelho Drimaren CL-5B Azul HF-RL

\begin{tabular}{|c|c|c|}
\hline & \multicolumn{2}{|c|}{ Solidez da cor à luz - método europeu } \\
\hline & $\begin{array}{l}\text { Alteração referência - escala } \\
\text { azul }\end{array}$ & $\begin{array}{l}\text { Alteração referência - escala } \\
\text { cinza }\end{array}$ \\
\hline Padrão & 5 & 4 \\
\hline $\begin{array}{l}\text { 1ํ Tingimento com } \\
\text { água de reuso }\end{array}$ & 5 & 4 \\
\hline $\begin{array}{l}\text { 2o Tingimento com } \\
\text { água de reuso }\end{array}$ & 5 & 4 \\
\hline
\end{tabular}

Sendo que referencia azul: 1: muito pobre e 8: excepcional solidez; Escala cinza: 1: grande alteração e 5: cor sem alteração.

Padrão

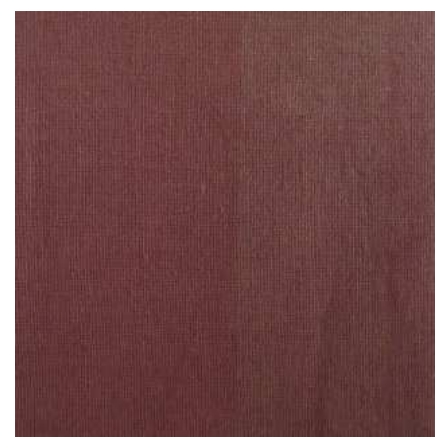

1ํ Tingimento com água

de reuso

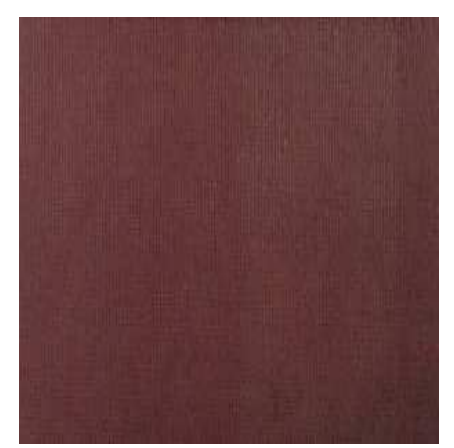

$2^{\circ}$ Tingimento com água

de reuso

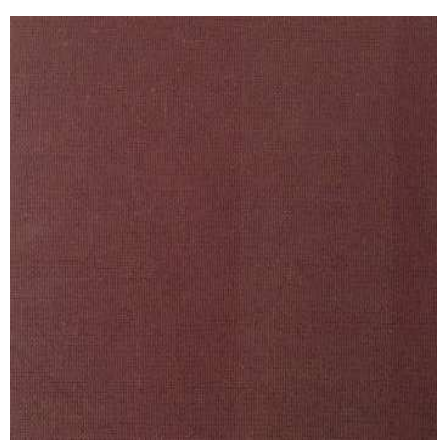

Figura 35 - Resultados dos ensaios de solidez da cor à luz dos tecidos tintos com a tricromia estudada. 


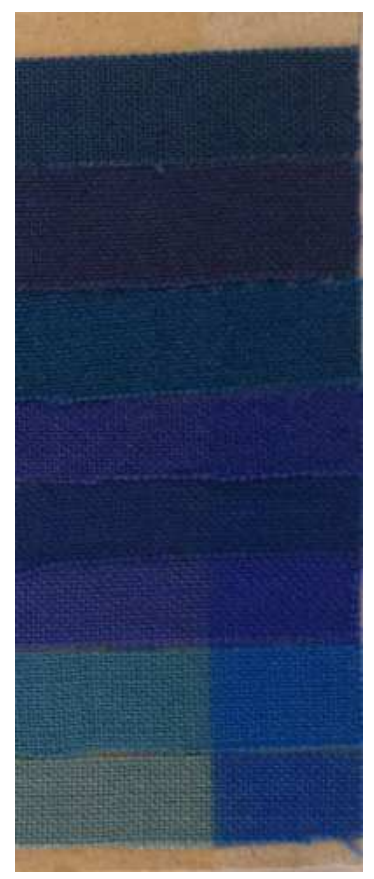

Figura 36 - Escala azul de referência que foi colocada com os tecidos tintos com a tricromia estudada. 


\section{CONCLUSÕES}

Em função dos resultados demonstrados neste trabalho, o tratamento realizado pelo método $\mathrm{H}_{2} \mathrm{O}_{2} / \mathrm{UV}$ mostrou-se eficiente para a remoção da cor presente no efluente produzido com os corantes amarelo Drimaren CL-2R, vermelho Drimaren CL-5B, azul Drimaren HF-RL e também quando estes são utilizados para compor a tricromia desejada, que foi o principal objetivo deste trabalho para comprovar a eficiência do tratamento nesta situação, uma vez que a mesma realmente condiz com o ambiente fabril.

Para a remoção da cor e reutilização da água, os resultados revelaram que houve uma redução das absorbâncias nas faixas de maior absorção dos efluentes produzidos tanto com os corantes individuais ou com a tricromia acima de 91,12 \pm $3,09 \%$, caracterizando assim, a possibilidade de reuso em um novo tingimento.

Foi verificado também que o $\mathrm{pH}$ é uma variável que influência no processo de degradação dos corantes, sendo que a melhor degradação da cor ocorreu em todos os experimentos no $\mathrm{pH} 4,0$.

Os resultados também demonstraram que o tempo de degradação tende a variar conforme o corante, uma vez que estes pertenciam a tricromia básica indicada pela empresa fabricante e os tempos de degradação foram diferentes, 150 minutos, 240 minutos e 150 minutos, para o amarelo, vermelho e azul respectivamente. Confirmando ainda estes resultados, a tricromia obteve o maior tempo de degradação que foi de 270 minutos, isto pode ser não apenas em função da combinação dos corantes tornarem este efluente mais resistente ao tratamento como também pelo fato de que para o tingimento da tricromia a somatória da porcentagem de concentração foi de $1,2 \%$ de corantes contra a executada com os corantes individuais que fora de $1,1 \%$.

A reutilização dos efluentes tratados provou ser possível em novos tingimentos durante mais de um tratamento, os resultados apresentaram diferenças de cor $(\Delta \mathrm{E})$ máxima de 0,62 , com isto permitindo a reutilização em até duas vezes desta água proveniente do processo fotoquímico. 
A água de reuso gerada a partir do tingimento com a tricromia estudada também permitiu a sua reutilização em até duas vezes, onde os $(\Delta \mathrm{E})$ foram de 0,25 e 0,47 . Contudo na terceira utilização se tornou inviável, uma vez que o $(\Delta \mathrm{E})$ foi de 2,28 e a eficiência da remoção de cor do efluente foi de $70,31 \pm 0,51 \%$.

Os ensaios de Carbono orgânico total (COT) confirmam os resultados citados acima, uma vez que o processo fotoquímico se mostrou eficiente para remoção de carga orgânica durante o primeiro e segundo tratamento apresentando resultados de $27,86 \%$ e $43,22 \%$. Na água de reuso gerada pelo terceiro tratamento esta redução de carga orgânica diminui para apenas 14,04\%.

Os tingimentos executados com a água de reuso provaram-se também que não interferem nos índices de solidez a lavagem e a luz, uma vez que os resultados dos ensaios realizados foram os mesmos dos tingimentos executados com a água potável.

Foi possível concluir que o elevado valor da condutividade nos banhos de tingimentos não é um fator restritivo para o reuso destes efluentes, visto que o cloreto de sódio pode ser reutilizado para o tingimento seguinte, fator este que se torna mais um ponto positivo, uma vez que representa economia de insumos durante o processo de tingimento. No segundo tingimento com a água de reuso proveniente do tingimento da tricromia, foi possível a economia de $3,79 \pm 0,01 \mathrm{~g} \cdot \mathrm{L}^{-1}$. Aparentemente em uma amostra de $5 \mathrm{~g}$, como foi à realização dos ensaios laboratoriais, parece uma economia ínfima, até porque o cloreto de sódio ou sulfato de sódio são insumos relativamente baratos. Entretanto se a análise for executada considerando uma máquina de produção de capacidade de $500 \mathrm{Kg}$, utilizando a mesma relação de banho praticada neste trabalho, teremos $5000 \mathrm{~L}$, gera uma economia de $18,95 \mathrm{Kg}$ de sal por tingimento, considerando que cada máquina produza 2 tingimentos por dia e trabalhe 22 dias por mês, esta economia será de $833,80 \mathrm{Kg}$ por mês, ou então $10005,6 \mathrm{Kg}$ por ano. Avaliado pelo aspecto financeiro, o custo de processo pode ser reduzido em $R \$ 1000,56$ por mês e ainda, $R \$$ 12006,72 por ano. 


\section{PERSPECTIVAS FUTURAS}

- Estudar o comportamento tricromia estuda, tentando utilizar como mecanismo fotoquímico a luz solar ao invés da lâmpada UV;

- Estudar a possibilidade de identificação e caracterização dos resíduos orgânicos;

- Estudar a eficiência desta metodologia em uma linha completa de corantes, não apenas utilizando a tricromia básica;

- Estudar o comportamento do processo fotoquímico, seguindo esta metodologia para outras classes de corantes tais como diretos, ácidos e dispersos;

- Utilizar esta metodologia, mantendo os mesmos parâmetros em um efluente industrial;

- Estudar a compatibilidade do processo fotoquímico com processos microbiológicos. 
ASSOCIAÇÃO BRASILEIRA DAS INDÚSTRIAS TÊXTEIS. Balanço 2011 e Perspectivas 2012, 2011. 25p. Disponível em: http://www.abit.org.br/site/publicacoes/arquivos pdf/Apresenta\%C3\%A7\%C3\%A30\% 20Coletiva\%20ABIT\%20jan2012\%20-Vers\%C3\%A30\%20Tabelas.pdf. Acesso em: 20 set. 2011.

Setor têxtil: exportações e mercado interno, 2012. Disponível em: http://www.abit.org.br/em pauta/paulo skaf.shtml. - Acesso em: 20 novembro. 2012.

ASSOCIAÇÃO BRASILEIRA DE NORMAS TÉCNICAS. NBR ISO-105-A01: Ensaios de solidez da cor - Parte A01: Princípios gerais do ensaio. Rio de Janeiro, 2006. 12 p.

NBR ISO - 105 - A02: Ensaios de solidez da cor - Parte A02: Escala cinza par avaliação da alteração da cor. Rio de Janeiro, 2006. 3 p.

NBR ISO - 105 - A03: Ensaios de solidez da cor - Parte B01: Solidez da cor à luz do dia. Rio de Janeiro, 2006. 2 p

NBR ISO -105 - A04: Ensaios de solidez da cor - Part. A04: Método para avaliação instrumental do grau de transferência da cor a tecidos testemunha. Rio de Janeiro, 2007. 2 p

NBR ISO -105 - A05: Ensaios de solidez da cor - Parte A05: Avaliação instrumental da alteração da cor para classificação da escala cinza. Rio de Janeiro, 2007. $4 \mathrm{p}$

NBR ISO - 105 - B01: Ensaios de solidez da cor - Parte A03: Escala cinza par avaliação da transferência da cor. Rio de Janeiro, 2009. 12 p.

. NBR ISO - 105 - B02: Ensaios de solidez da cor - Parte B02: Solidez da cor à luz artificial: Ensaio da lampada de desbotamento de arco de xenônio. Rio de Janeiro, 2008. $19 \mathrm{p}$.

NBR ISO - 105 - C06: Ensaios de solidez da cor - parte C06: Solidez da cor à lavagem doméstica e comercial. Rio de Janeiro, 2010. 10 p.

ABRAHÃO, A. J., SILVA, G. A. Influência de alguns contaminantes na toxicidade aguda de efluentes da indústria têxtil". Revista Química Têxtil, São Paulo, v.67, pp. 8-34, jun 2002.

ALCÂNTARA, M.; R. DALTIN, D. A. A química do processamento têxtil. Revista Química Nova, São Paulo, v. 19, n.3, p. 320-330,1996.

ALONSO, H. S. M. P. Estudo do efeito do tratamento por laser de $\mathrm{CO}_{2}$ nas propriedades superficiais de fibras sintéticas. 2008. 109 f. Dissertação (Mestrado em Química Têxtil ) - Universidade do Minho, Portugal, 2008.

ARAUJO, F. V. F.; YOKOYAMA, L. Remoção de cor em soluções de corantes reativos por oxidação com $\mathrm{H}_{2} \mathrm{O}_{2} / \mathrm{UV}$. Revista Química Nova, São Paulo, v. 29, n.1, p. 11-14, 2006. 
ALMEIDA, R. S. A industrialização e a questão ambiental na região sudeste do Brasil. Revistas Eletrônicas Caminhos da Geografia, Rio de Janeiro, v. 4, n. 11, pag. 53-66, fev. 2004. Disponível em: http://www.seer.ufu.br/index.php/caminhosdegeografia/article/view/15325/8624 acesso em 06 jan. 2012.

AL-MOMANI, F.; TOURAUD, E.; DEGORCE-DUMAS, J. R.; ROUSSY, J.; THOMAS, O. Biodegradability enhancement of textile dyes and textile wastewater by VUV photolysis. Journal of Photochemistry and Photobiology, v.153, p 191-197, 2002.

ALVES, P. A. Tratamento eletroquímico e eletroquímico foto-assistido na degradação de efluentes da indústria têxtil. 2010. 103 f. Dissertação (Mestrado em Ciências) - Instituto de Química de São Carlos, Universidade de São Paulo, São Paulo, 2010.

AZEVEDO, J. A. H.; LIMA, M. R. P. ; SALGADO, B. C. B. ; PESSOA, K. A. R. ; ARAUJO, R. S. Estudo comparativo da degradação avançada de corante índigo via processos fotoassistidos e de catalise heterogênea. In: CONNEPI Congresso NorteNordeste de Pesquisa e Inovação, 2010, Maceió. Resumos V CONNEPI Maceió, 2010.

BALI, U.; ÇATALKAYA, E.; SENGUL, F. - Photodegradation of Reactive Black 5, Direct Red 28 and Direct Yelow 12 using UV, UV/ $\mathrm{H}_{2} \mathrm{O}_{2}$ and $\mathrm{UV} / \mathrm{H}_{2} \mathrm{O}_{2} / \mathrm{Fe}^{+2}$ : a comparative study. Journal of Hazardous Materials, v. B114, p. 159-166, 2004.

BARRETO, N. S. E. Descoloração e detoxificação do azo corante alaranjado II por geobacillus stearothermophilus, pseudomonas aeruginosa $\mathrm{e}$ p. fluorescens isolados e em cultura mista. 2006. 192 f. Tese (Doutorado em Engenharia Química) - Universidade Federal de Pernambuco, Recife, 2006.

BELTRAME, L. T. C. Caracterização de efluente têxtil e proposta de tratamento. 2000. 179 f. Dissertação (Mestrado em Engenharia Química) - Universidade Federal do Rio Grande do Norte, Natal - RN, 2000.

BRASIL, Lei 6938 de 31 de agosto de 1981. Dispõe sobre a Política Nacional do Meio Ambiente, seus fins e mecanismos de formulação e aplicação, e dá outras providencias. Disponível em: http://www.planalto.gov.br/ccivil 03/leis/L6938.htm Acesso em: 30 nov. 2012.

BRITO, N. N., SILVA V. B. M. Processo oxidativo avançado e sua aplicação ambiental. Revista Eletrônica de Engenharia Civil, Goiânia - GO, v.1, n.3, p. 3647, 2012. Disponível em http://www.revistas.ufg.br/index.php/reec/article/view/17000/10840 - acesso 18/07/2014.

BRUNELLI, T. F. T.,GUARALDO T. T., PASCHOAL F. M. M., ZANONI M. V. B. Degradação fotoeletroquímica de corantes dispersos em efluente têxtil utilizando foto ânodos de Ti/TiO2. Revista Química Nova, São Paulo, v.1, n.32, p. 67-71, 2009.

BURTI, C. et al. Processos Produtivos Têxteis I. 5. ed. São Paulo: Escola SENAI Francisco Matarazzo - Apostila do Curso Técnico Têxtil, 2011. 214 p. 
BANCO NACIONAL DO DESENVOLVIMENTO. BNDES 50 Anos - Histórias Setoriais: O Complexo Têxtil. Rio de Janeiro, 2002. 28 p. Disponível em: http://www.bndes.gov.br/SiteBNDES/export/sites/default/bndes pt/Galerias/Arquivos/ conhecimento/livro setorial/setorial11.pdf - Acesso em: 05 jan. 2012.

CATANHO, M.; MALPASS, G. R. P.; MOTHEO, A. J. Photoelectrochemical treatment of the dye reactive red 198 using DSA® electrodes. Applied Catalysis B. Environmental, São Paulo, v.62, p. 193-200, 2006.

CAVALCANTE, A.M.; DEZOTTI, M.W.C.; SANT'ANNA JR, G.L. Técnicas oxidativas para a remoção de matéria orgânica de uma corrente de soda exausta de refinaria de petróleo. 2005. 145 p. Dissertação (Mestrado em Ciências em Engenharia Química) - Universidade Federal do Rio de Janeiro, 2005.

CIBA Brasil. Tendências Industriais, 2001. Sao Paulo, Brasil.

CLARIANT. Cartela de cores outono/inverno. São Paulo, 2005. 12 p.

CLAUSEN, D. N.; TAKASHIMA, K. Efeitos dos parâmetros operacionais na fotodegradação do azo corante direct red 23 na interface dióxido de titânio/água. Revista Química Nova, Londrina . v. 30, n.8, p. 1896-1899, 2007.

CONFEDERAÇÃO NACIONAL DA INDUSTRIA.ASSOCIAÇÃO BRASILEIRA DA INDUSTRIA TEXXTIL E DE CONFECÇÃO. Têxtil e Confecção: Inovar, Desenvolver e Sustentar, Brasília: Cni/abit, p. 74, 2012. Disponível em: <http://arquivos.portaldaindustria.com.br/app/conteudo_18/2013/09/23/4970/201310 02174510609604 i.pdf $>$. Acesso em: 05 ago. 2014.

CONSELHO NACIONAL DO MEIO AMBIENTE( CONAMA). Resolução 20, de 18 de junho de 1986. Legislação Federal sobre Classificação das Águas (potabilidade/balneabilidade) e Poluição das Águas. Disponível em: http://www.mma.gov.br/port/conama/res/res86/res2086.html - Acesso em: 30 dez. 2012.

CONSELHO NACIONAL DO MEIO AMBIENTE( CONAMA). Resolução 357, de 17 de março de 2005. Dispõe sobre a classificação dos corpos de água e diretrizes ambientais para o seu enquadramento, bem como estabelece as condições e padrões de lançamento de efluentes, e dá outras providencias. Disponível em: http://www.mma.gov.br/port/conama/res/res05/res35705.pdf - Acesso em: 30 dez. 2012

COMPANHIA PERNAMBUCANA DO MEIO AMBIENTE. Roteiro complementar de licenciamento e fiscalização para a tipologia têxtil. Recife, 2001. 125 p. Disponivel em: http://www.cprh.pe.gov.br/downloads/roteiro-textil.pdf - Acesso em: 30 dez. 2012

CONCHON, J. A. Tratamento de Efluentes na Indústria Têxtil. Revista Base Têxtil, da Federación Argentina de la Industria Têxtil, Argentina, v. 123, n. 1, p.1-5, 1999.

DIAS, F. F. S.; LIRA, R. J.; CHIAVONE-FILHO, O.; CARVALHO, F. O.; PACHECO J. G. Degradação de corante Reative Black 5 via processo foto-fenton em reator PTC com modelagem e otimização utilizando RNA. Scientia Plena, v. 9, n. 10, 2013. 
Disponível em : http://scientiaplena.emnuvens.com.br/sp/article/view/1286/896 acesso em 06/06/2014.

ESTEVES, F. de A. Fundamentos de Limnologia 2.ed. Interciência. Rio de Janeiro, 1998. 601p.

FERNANDES, R. L.; CARIO, S. A. F. Desempenho comercial e padrão de concorrência internacional: uma analise do setor têxtil-confecções catarinense entre 1996 e 2006. Revistas Eletrônicas da Fundação de Economia e Estatística, Santa Catarina, 2008. Disponível em: http://revistas.fee.tche.br/index.php/indicadores/article/viewFile/2218/2639 - acesso em 18 Dez 2012.

FERREIRA, I. L. S.; MAURICIO, L. P. A; AQUINO, M.S; OLIVEIRA, F. R. Aplicação de materiais têxteis na área da saúde. In: CONTEXMOD CONGRESSO CIENTíFICO TÊXTIL E DE MODA, 2., 2014, São Paulo. Anais eletronico. São Paulo, $2014 . \quad$ Disponivel em: http://www.contexmod.net.br/index.php/segundo/article/view/201/104- Acesso em 18 nov. 2015.

FERREIRA, D. D. M.; KELLER, J.; SILVA, L. E. A utilização da água pela indústria têxtil: uma pesquisa no município de Brusque, SC. Inter Sciense Place, Santa Catarina, v. 8, n. 2, p. 1-19, 2009.

FREIRE, R. S.; PELEGRINI, R.; KUBOTA, L. T.; DURAN, N. Novas tendências para o tratamento de resíduos industriais contendo espécies cloradas. Revista Química Nova, São Paulo, v.23, n.4, p. 1362-1366, 2000.

GAHR, F.; HERMANUTZ, F.; OPPERMANN, W. Ozonation - an important technique to comply with new German laws for textile wastewater treatment. Water Science and Technology, v.30, p. 255-263, 1994.

GOVEIA, J. C. Estudo colorimétrico da translucidez de materiais restauradores. 2004. 113 f. Dissertação (Mestrado em Odontologia) - Faculdade de Odontologia, Universidade de São Paulo, São Paulo, 2004.

Guarantini, C. C. I. e Zanoni, M. V. B. Corantes têxteis. Revista Química Nova, São Paulo, v.23,n.1, p. 71-78, 2000.

HASSEMER, M. E. N. Oxidação fotoquímica - UV/ $\mathrm{H}_{2} \mathrm{O}_{2}$ para degradação de poluentes em efluentes da indústria têxtil. 2006. $175 \mathrm{f}$. Tese (Doutorado em Engenharia Ambiental) - Universidade Federal de Santa Catarina, Florianópolis, 2006.

HASSEMER, M. E. N.; CORAL, L. A.; LAPOLLI, F. R.; AMORIM, M. T. S. P. Processo UV/H2O2 como pós-tratamento para remoção de cor e polimento final em efluentes têxteis. Revista Química Nova, Florianopolis. v. 35, n.5, p. 900-904, 2012.

HUERTAS, R.; MELGOSA, M; HITA, E. Influence of random-dot textures on perception of suprathreshold color differences. Revista Química Nova, Granada Espanha, v. 23, n.9, p. 2067-2076, set 2006. 
IMMICH, A. P. S. Remoção de corantes de efluentes têxteis utilizando folhas de azadirachta indica como adsorvente. 2006. 119 f. Dissertação (Mestrado em Engenharia Química) - Universidade Federal de Santa Catarina, Florianópolis , 2006.

KALSOOM, U.; ASHRAF, S.S.; MEETANI, M. A.; RAUF, M. A.; BHATTI, H. N. Degradation and kinetics of $\mathrm{H}_{2} \mathrm{O}_{2}$ assisted photochemical oxidation of Remazol Turquoise Blue. Chemical Engineering Journal, Paquistao, v. 200 -202, n. 15, p. 373-379, 2012.

KIMURA, I. Y.; JR. GONÇALVES, A. C.; STOLBERG, J.; LARANJEIRA, M. C. M.; FÁVERE, V. T. Efeito do $\mathrm{pH}$ e do tempo de contato na adsorção de corantes reativos por microesferas de quitosana. Revista Polímeros: Ciência e Tecnologia, Maringá - PR, v. 9, n.3, p. 51- 57, Jul - Set 1999.

KUNZ, A.; PERALTA-ZAMORA, P.; MORAES, S. G.; DURÁN, N. Novas tendencias no tratamento de efluentes texteis. Revista Química Nova, Curitiba, v. 25, n.1, p. 78-82, 2002. Disponível em: http://www.scielo.br/pdf/qn/v25n1/10428.pdf - acesso em 10/04/2014.

LACERDA, J. P. Estudo do impacto ambiental nos cursos d'agua causado pelo lançamento de efluentes industriais no município de Itabirito/ MG. 2004. 108 f. Dissertação (Mestrado em Engenharia Ambiental) - Universidade Federal de Ouro Preto, Ouro Preto, 2004.

LAU, Y. Y.; WONG, Y. S.; TENG, T. T.; NORHASHIMAH, M., MOHD, R.D.; RAFATULLAH, M.; ONG, S. A. Coagulation-flocculation of azo dye Acid Orange 7 with green refined laterite soil. Chemical Engineering Journal, Malasia, v. 246, p. 383-390, 2014.

LIZAMA, C.; FREER, J.; BAEZA, J.; MANSILLA, D. Optimized photodegradation of Reactive Blue 19 on $\mathrm{TiO}_{2}$ and $\mathrm{ZnO}$ suspensions. Catalysis Today, Chile, v. 76, p. 235-246, 2002.

LOURENÇO, F. Indústria têxtil fica US\$10 bi menor. Diário do Comércio, São Paulo, Dez $2012 . \quad$ Disponível em: http://www.dcomercio.com.br/index.php/economia/sub-menu-economia/101348industria-textil-fica-us-10-bi-menor - acessado em 04/01/13.

LUCAS, M.; JEREMIAS, P. F. P.; ANDREAUS, J.; BARCELLOS, I. O.; ZAMORA, P. $P$. Reutilização de efluente de tingimentos de fibras acrílicas pós-tratamento fotoeletroquímico. Revista Química Nova, Blumenau, v.31, n.6, p. 504-511, ago. 2008.

MACHADO, V. R.; STÜLP, S. Avaliação de um sistema oxidativo avançado aplicado na degradação do corante orgânico rodamina-B. Revista Jovens Pesquisadores, Santa Cruz do Sul-RS. v.3, n.1, p. 67-77, 2013. Disponível: https://online.unisc.br/seer/index.php/jovenspesquisadores/article/view/3579/2669acesso 03/06/2014.

MANETTI, D. R.; BORBA, F. H.; MÓDENES, A. N.; ESPINOZA-QUINONES, F. R.; PALÁCIO, S. M.; VILAR, V. J. P; BERGAMASCO, R. Avaliação do desempenho de um sistema de tratamento utilizando os processos eletrocoagulação e foto-fenton integrados no tratamento de um efluente têxtil . Revista Engevista, Paraná, v.16, 
n.3, p. 420-431, $2014 . \quad$ Disponível: http://www.uff.br/engevista/seer/index.php/engevista/article/view/519/288. - acesso em 18/07/2014.

MARMITT , S.; PIROTTA, L. V.; STÜLP, S. Aplicação de fotólise direta e UV/H2O2 a efluente sintético contendo diferentes corantes alimentícios. Revista Química Nova, Rio Grande do Sul, v.33, n.2, p. 384-388, 2010.

MATTOS, I. L.; SHIRAISHI, K. A.; BRAZ, A. D.; FERNANDES, J. R. Peróxido de hidrogênio: importância e determinação. Revista Química Nova, Minas Gerais, v.26, n.3, p. 373-380, 2003.

MORAES, C. M. Estudo da difusão de corantes reativos em tecido de algodão. 2010. 105 f. Dissertação (Mestrado em Engenharia Química) Universidade Estadual de Campinas, Campinas - SP, 2010.

PERES, C. S.; ABRAHÃO, A. J. Características e sistemas de tratamento de águas residuais das indústrias têxteis. Revista Química Têxtil, São Paulo, v.21, p 22-39, 1998.

RIBEIRO, J. P.; OLIVEIRA, J.T.; OLIVEIRA, A. G.; ABDALA NETO, E. F.; SANTOS, A. B.; NASCIMENTO, R. F. Degradação do corante Remazol vermelho RB por $\mathrm{H}_{2} \mathrm{O}_{2} /$ UV. Revista AIDIS de Ingenieria y Ciencias Ambientales: Investigación, desarrollo y práctica, México, v.6, no3, p 76-86, 2013.

ROCHA, R. S.; REIS, R.M.; BEATI, A. A.G.F.; LANZA, M. R.V. Desenvolvimento e avaliação de eletrodos de difusão gasosa( EDG) para geração de $\mathrm{H} 2 \mathrm{O} 2$ in situ e sua aplicação na degradação do corante reativo azul 19. Revista Química Nova, São Paulo, v.35, n.10, p. 1961-1966, 2012.

ROSA, J. M. Sustentabilidade no beneficiamento têxtil: produção de tingimentos com reuso de efluente tratado por fotocatálise via UV/ $\mathrm{H}_{2} \mathrm{O}_{2} .2010$. 79 f. Dissertação (Mestrado em Engenharia de Produção) - Universidade Nove de Julho, São Paulo, 2010.

SAITO, G.; MOURA, M.; SANTOS M. O. H. H. Controle de resíduos aplicados na indústria têxtil: analise da redução de insumos, gestão no descarte de materiais e mensuração da economia financeira após a sua aplicação. 2010. 36f. Trabalho de conclusão de curso (Engenharia de Produção) - Universidade Anhembi Morumbi, São Paulo 2010.

SALEM, V. Tingimento têxtil : fibras, conceitos e tecnologia. 1。 edição, Edgard Blucher. São Paulo, 2010. 300 p.

SALGADO, B. C. B; NOGUEIRA, M. I. C.; RODRIGUES, K. A.; SAMPAIO, G. M. M. S.; BUARQUE, H. L. B.; ARAÚJO, R. S. Descoloração de efluentes aquosos sintéticos e têxtil contendo corantes índigo e azo via processos Fenton e fotoassistidos (UV e UV/ $\mathrm{H}_{2} \mathrm{O}_{2}$ ). Engenharia Sanitária e Ambiental, v. 14, n. 1, p. 1-8, jan-mar 2009.

SANTANA, C. M. Estudo da degradação de corantes têxtil em matrizes aquosas por meio dos processos oxidativos avançados $\mathrm{O}_{3}-\mathrm{H}_{2} \mathrm{O}_{2} / \mathrm{UV}$ e foto- 
fenton. 2010. 120 f. Dissertação (Mestrado em Engenharia Química) - Escola Politécnica, Universidade de São Paulo, São Paulo, 2010.

SANTOS, V.L.; SILVA, P. T.S.; SILVA, R. F.; ALBUQUERQUE E. C. Avaliação do processo fenton solar no tratamento de efluente gerado por lavanderia de jeans de Pernambuco. In COBEQ- Congresso Brasileiro de Engenharia Química, 19., 2012. Búzios. Anais eletronicos. Buzios, 2012. Disponivel em: http://ainfo.cnptia.embrapa.br/digital/bitstream/item/76687/1/Paulo-tereza-2012-1.pdf

- Acesso em 18 ago. 2014.

SAO PAULO, Decreto $\mathrm{n}^{\circ}$ 8.468, de 08 de setembro de 1976. Dispõe sobre a prevenção e o controle da poluição do meio ambiente, São Paulo.

SCHIMIDT, T. M. P.; SANTANA, V. S. Degradação fotocatalítica do efluente do curtimento ecológico de peles de peixe. In: ENCONTRO PARANAENSE DE ENGENHARIA E CIENCIA, 3., 2013, Paraná. Anais eletronico. Paraná, 2013. Disponivel em: http://www.unioeste.br/eq/iiiepec/artigos/Trab29Schimidt\%20et\%20al.pdf-- Acesso em 18 nov. 2014.

SENAI SP. Beneficiamentos Têxteis: Colorimetria. 1. ed. São Paulo: Escola SENAI Francisco Matarazzo - Apostila do Curso de Formação Continuada, 2004. 48 p.

SENAI SP. Curso Técnico Têxtil: Beneficiamentos Têxteis II. 1. ed. São Paulo: Escola SENAI Francisco Matarazzo - Apostila do Curso Técnico Têxtil, 2012. 62 p.

SENAI SP. Curso Técnico Têxtil: Beneficiamentos Têxteis III. São Paulo: Escola SENAI Francisco Matarazzo - Apostila do Curso Técnico Têxtil, 2013. 155 p.

SERAFINI, Fernanda Rosa. Proposta de Plano de Gerenciamento de Resíduos Sólidos para uma Indústria Têxtil do município de Vila Maria - RS, com base na Produção mais Limpa. 2013. 75 f. Tese (Doutorado) - Curso de Engenharia Ambiental, Faculdade de Engenharia e Arquitetura da Universidade de Passo Fundo, Passo 2013.2 Disponível em: <http://usuarios.upf.br/ engeamb/TCCs/2013-2/Fernanda Rosa Serafini.pdf>. Acesso em: 15 ago. 2014.

SILVA, B. B.; CUSTÓDIO, V.; PESSOA, E.; COIMBRA, J. L.; NEUMAN, V.; JACUBAVICIUS, C.; FADINI, R.; SILVA, S. S.; RODRIGUES, V. B.; ROSA, J. M. Processos Produtivos Têxteis II. 4. ed. São Paulo: Escola SENAI Francisco Matarazzo - Apostila do Curso Técnico Têxtil, 2011. 298 p.

SILVA, B. B.; CUSTÓDIO, V.; PESSOA, E.; COIMBRA, J. L.; NEUMAN, V.; JACUBAVICIUS, C.; FADINI, R.; SILVA, S. S.; RODRIGUES, V. B.; ROSA, J. M. Processos Produtivos Têxteis III. 4. ed. São Paulo: Escola SENAI Francisco Matarazzo - Apostila do Curso Técnico Têxtil, 2011. Apostila do Curso Técnico Têxtil. $313 \mathrm{p}$.

SILVA, S. C. da. TRATAMENTO QUÍMICO E BIOLÓGICO DE EFLUENTES DA INDÚSTRIA TÊXTIL COMO FORMA DE REDUÇÃO DO IMPACTO AMBIENTAL AOS RECURSOS HÍDRICOS. Estudo de Caso: Mar Indústria Têxtil e Tinturaria Ltda. 201 
2011. Disponível em: <http://repositorio.unesc.net/bitstream/handle/1/1029/Simone Custódio Da Silva.pdf?sequence=1>. Acesso em: 03 ago. 2014.

SLOKAR, Y. M.; LE MARECHAL, A. M. Methods of decoloration of textile wastewaters. Dyes and Pigments, Eslovenia, v.37, n.4, p. 335-356, 1998.

SOUZA, C. R. L. Degradação de corantes reativos e remediação de efluentes têxteis por processos avançados envolvendo ferro metálico. 2006. 100 f. Dissertação (Mestrado em Ciências Exatas) - Universidade Federal do Paraná, Curitiba, 2006

WEID, E. V. D. A indústria têxtil no Brasil. Estudo de caso de uma empresa do rio de Janeiro. Fontes documentais. Revista Eletrônica America Latina en La Historia Economica, Rio de Janeiro, v.2, n. 4, jul-dez. 1995. Disponível em: http://alhe.mora.edu.mx/index.php/ALHE/article/viewFile/51/46 - acesso em 28 Dez 2012.

RIBEIRO, F. W. P.; OLIVEIRA, S. N.; LIMA-NETO, P.; CORREIA, A. N.; MASCARO, L. H.; MATOS, R.; SOUZA, E. C. P.; LANZA, M. R. V. Eletrodegradação de ponceau 2R utilizando ânodos dimensionalmente estáveis e Ti/Pt. Revista Química Nova, São Paulo, v. 36, n. 1, p. 85-90, 2013. Disponível em: http://submission.quimicanova.sbq.org.br/qn/qnol/2013/vol36n1/15-AR12372.pdf acesso em 28 Mar 2014.

RIBEIRO, V. A. S.; VOLPE, A. L. S.; TAVARES, C. R. G. Fotodegradação de efluentes têxteis catalisada por $\mathrm{ZnO}$ e classificação do resíduo sólido gerado. In: CONGRESSO INTERNACIONAL DE TECNOLOGIAS PARA O MEIO AMBIENTE, 3., 2012, Bento Gonçalves. Anais eletronico. Bento Gonçalves, 2012. Disponivel em: http://www.proamb.com.br/downloads/1ka35d.pdf-- Acesso em 18 nov. 2014.

TWARDOKUS, R. G. Reuso de água no processo de tingimento da indústria têxtil. 2004. 136 f. Dissertação (Mestrado em Engenharia Química) - Centro Tecnológico, Universidade Federal de Santa Catarina, Florianópolis, 2004.

TANG W. Z. e AN H. UV/TiO2 Photocatalytic oxidation of commercial dyes in aqueous solutions. Chemosphere, Miami, V.31, n.9, p.4157-4170, 1995.

TEIXEIRA, C. P. A. B.; JARDIM, W. F. Caderno Temático: Processos Oxidativos Avançados - Conceitos Teóricos, Unicamp- Campinas, v.3, 2004.

TOLEDO, R. A. S., Tecnologia da Reciclagem. Química Têxtil, São Paulo, v. 74, p. 8-14, Março de 2004.

US PEROXIDE. BOD and COD redution using hydrogen peroxide. Atlanta, 2012. $1 \quad$ p. Disponível em: http://www.h202.com/industrial/applications.aspx?pid=89\&name=Rapid-Response Acesso em: 20 set. 2012.

VAINER, C.B. Recursos hidráulicos: questões sociais e ambientais. Revista Estudos Avançados, Rio de Janeiro, v.21, n. 59, p. 119-137, 2007.

VOLOSHIN, Y.; RAGHUNATH, H.; LAWAL, A. Kinetics of hydrogen peroxide synthesis by direct combination of $\mathrm{H}_{2}$ and $\mathrm{O}_{2}$ in a microreactor. Catalysis Today, Estados Unidos da América, v. 125, p. 40-47, 2007. 
ZANELLA, G.; SCHARF, M.; VIEIRA, G. A. Tratamento de banhos de tingimento têxtil por processos foto-fenton e avaliação da potencialidade do reuso. Revista Química Nova, v.33, n.5, p. 1039-1043, 2010. 